FERNANDA CRISTINA FERREIRA

\title{
AS CONDIÇÕES QUE LEVAM AS MULHERES SOROPOSITIVAS AO HIV/AIDS A ABRIR A PRIVACIDADE DE SUAS INFORMAÇÕES ÀS EQUIPES DO PROGRAMA SAÚDE DA FAMÍLIA
}

Dissertação apresentada à Escola de Enfermagem da Universidade de São Paulo para obtenção do título de Mestre em Enfermagem em Saúde Coletiva.

Área de concentração:

Enfermagem em Saúde Coletiva

Orientadora:

Prof $^{a}$. Dr ${ }^{a}$. Lúcia Y. Izumi Nichiata 
Catalogação na Publicação (CIP) Biblioteca "Wanda de Aguiar Horta" Escola de Enfermagem da Universidade de São Paulo

Ferreira, Fernanda Cristina.

As condições que levam as mulheres soropositivas ao HIV/AIDS a abrir a privacidade de suas informações às equipes do Programa Saúde da Família. / Fernanda Cristina Ferreira. - São Paulo, 2007.

$155 \mathrm{p}$.

Dissertação (Mestrado) - Escola de Enfermagem da Universidade de São Paulo.

Orientadora: Prof $^{a}$ Dr $^{a}$ Lúcia Yasuko Izumi Nichiata

1. Síndrome da Imunodeficiência Adquirida 2. Saúde da mulher 3. Comunicação sigilosa. I. Título. 

Autorizo, exclusivamente para fins acadêmicos e científicos, a reprodução total ou parcial desta dissertação, por processos fotocopiadores.

Assinatura:

Data:

\section{DEDICATÓRIA}


À minha mãe pelo carinho e incentivo aos estudos Ao meu pai pelo suporte oferecido nestes anos estudo À minha irmã querida pelo apoio, incentivo e auxílio em determinados momentos na construção deste trabalho

\section{AGRADECIMENTOS}


À $\operatorname{prof}^{a}$ Dr $^{\mathrm{a}}$ Lúcia Y. Izumi Nichiata pela orientação e auxílio no caminho da construção deste trabalho.

À Prof ${ }^{\mathrm{a}} \operatorname{Dr}^{\mathrm{a}}$ Elma Lourdes Campos Pavone Zoboli e à Dr ${ }^{\mathrm{a}}$ Kátia Cristina Bassichetto pelos apontamentos, contribuições e por aceitar o convite para participar da banca examinadora.

À Prof ${ }^{a}$ Dr $^{a}$ Sayuri Tanaka Maeda pelo carinho, incentivo, compreensão e generosidade.

À Prof ${ }^{a}$ livre-docente Miriam Aparecida Barbosa Merighi, por minha iniciação à pesquisa científica e pelos ensinamentos jamais esquecidos.

À Prof ${ }^{a} \operatorname{Dr}^{a}$ Anna Luiza de Fátima Pinho Lins Gryschek e a $\operatorname{Prof}^{a} \operatorname{Dr}^{a}$ Lúcia Maria Frazão Helene pelo apoio.

Aos funcionários da Biblioteca Wanda de Aguiar Horta, pelo auxílio e suporte durante o desenvolvimento deste trabalho.

Aos funcionários do Departamento de Saúde Coletiva e aos funcionários da Secretaria de Pós-Graduação pelo convívio, suporte e palavras de incentivo.

Aos funcionários do SAE-Butantã que contribuíram de forma crucial para a execução da coleta dos dados.

Às mulheres entrevistadas, sujeitos anônimos desta pesquisa, que contribuíram com suas vivências e disponibilidade, sem elas não seria possível a realização deste trabalho.

Às minhas amigas Heloise de Bastos Navarausckas e Patrícia Mayumi Machado Shiroma pela amizade de tantos anos, ajuda nos momentos difíceis e contribuições durante o desenvolvimento deste trabalho. 
À Prof ${ }^{a}$ Isabel Celeste de Bastos Navarausckas pelo carinho e pela revisão de português, essencial para a finalização do estudo.

À Prof ${ }^{a}$ Mestre Elizabeth Braz, pela amizade, cumplicidade e contribuições.

Ao querido Gustavo Marin, pela compreensão, apoio, suporte, carinho e parceria.

À Mônica de Farias Martins pelo suporte, apoio e incentivo.

À CAPES pelo apoio financeiro durante o mestrado. 


\section{RESUMO}

Ferreira FC. As condições que levam as mulheres soropositivas ao HIV/AIDS a abrir a privacidade de suas informações às equipes do programa saúde da família. São Paulo (SP): Escola de Enfermagem, Universidade de São Paulo; 2007.

A aids é uma doença infecciosa que aparece na década de 1980. Desde sua descoberta até os dias atuais houve mudanças nas características das pessoas infectadas. Uma dessas mudanças foi a feminização. As mulheres devido às questões de gênero possuem singularidades na forma do enfrentamento da doença. $O$ acompanhamento das mulheres infectadas pelo HIV é realizado principalmente, por serviços especializados de saúde. Depois da criação do Programa Saúde da Família, em 1994, e o incentivo às ações de promoção à saúde e prevenção do HIV na atenção básica, torna-se de suma importância a discussão de temas sobre bioética no caso da aids no PSF. O PSF adentra as residências das famílias e tem uma relação de maior proximidade com a comunidade, e incorpora um novo trabalhador que é o Agente Comunitário de Saúde. É a mulher infectada pelo HIV que tem o direito de decidir a quem, como, onde e quando a informação sobre sua soropositividade deve ser revelada. Este estudo teve como objetivos descrever em que condições as mulheres infectadas pelo HIV abrem sua privacidade em relação a informação sobre o diagnóstico de soropositividade a familiares, amigos e vizinhos; e identificar quais as motivações para abrir a privacidade de informações para a equipe de PSF das mulheres infectadas pelo HIV/AIDS. Trata-se de um estudo descritivo de natureza qualitativa, com enfoque bioético, realizado no Município de São Paulo, com mulheres em acompanhamento em um serviço especializado em DST/AIDS e cadastradas por uma equipe de PSF. Verificou-se neste estudo que as mulheres infectadas pelo HIV/AIDS revelam a sua condição de soropositividade a família, amigos e vizinhos quando há identificação com outro soropositivo, pressão de outros, confiança depositada em uma relação, vontade de busca de apoio, preocupação com possível transmissão do vírus ao parceiro, quando houve experiências positivas de apoio, e quando não consegue mentir quando questionada sobre sua soropositividade. E não revelam quando há medo do preconceito, medo de ex-parceiros, medo de se expor, houve experiências negativas como falta de apoio, rejeição e disseminação da informação, foi estabelecido uma pacto de silêncio, não querem que sintam pena, há medo de que a relação mude, envolve filhos menores de idade, preferem guardar para si e quando utilizam estratégias para manter o segredo. As mulheres abrem a privacidade do diagnóstico para a equipe de PSF quando o diagnóstico de soropositividade foi feito na própria unidade, quando ela sente que é melhor atendida no PSF por ser portadora do HIV, tem vínculo com os profissionais do PSF como se fossem familiares, confiam nos profissionais do PSF, sentem que os profissionais não sentem pena. E, não revelam quando a atitude inadequada do profissional gerou medo e insegurança quando comunicou à usuária o diagnóstico, acham que o PSF está ligado ao cuidado de pessoas com doenças graves e acamados, não confiam nesses profissionais por medo de quebra do sigilo,e já possuem todo suporte assistencial no SAE.

Descritores: aids, Saúde da Mulher, comunicação sigilosa. 


\begin{abstract}
Ferreira FC. As condições que levam as mulheres soropositivas ao HIV/AIDS a abrir a privacidade de suas informações às equipes do programa saúde da família. [The conditions the infected women by the HIV open its privacy in relation the information on the diagnosis of positive HIV's result to Family Health Program] São Paulo (SP): Escola de Enfermagem, Universidade de São Paulo; 2007.
\end{abstract}

The AIDS is an infectious illness that appears in the decade of 1980. Since its discovery until the current days, it has been had changes in the characteristics of the infected people, one of these changes was the 'femininity'. The women, due to the sort questions, possess peculiarities in the form of the confrontation of the illness. The accompaniment of the infected women by the HIV is carried through, mainly, for specialized services. After the creation of the Family's Health Program, in 1994, and the incentive to the actions of health promotion and prevention of the HIV in the basic attention, becomes of utmost importance to discuss subjects on bioethics in the case of the AIDS in the PSF. The PSF goes to inside the families' residences and has a relation of bigger proximity with the community and it incorporates a new worker who is the Communitarian Agent of Health. That's the woman who is infected by the HIV who has the right to decide to who, as, where and when the information on its positive HIV's result must be disclosed. This study had as objective to describe where conditions the infected women by the HIV open its privacy in relation the information on the diagnosis of positive HIV's result to their family, friends and neighbors; and to identify which are the motivations to open the privacy of information for the team of PSF of the infected women for the HIV/AIDS. One is about a descriptive study of qualitative nature, with bioethics approach, carried through in the City of São Paulo, with women in accompaniment in a specialized service in DST/AIDS and registered in cadastre by a PSF team. It was verified in this study that the infected women by the HIV/AIDS disclose to its condition of positive HIV's result to the family, friends and neighbors when she has identification with another who has positive HIV diagnosis, pressure of others, confidence deposited in the relationship, wish of support search, concern with possible transmission of the virus to the partner, when it had positive experiences of support, e when it does not obtain to lie when questioned on its positive HIV's result. And she does not disclose when it has fear of the preconception, fear of former-partners, fear of if displaying, had negative experiences as lack of support, rejection and dissemination of the information, was established a silence pact, does not want that they feel penalty, has fear of that the relation moves, involves minor children, prefers to keep for itself and when they use strategies to keep the secret. Women open privacy of diagnosis for team of PSF when diagnosis of positive HIV's result was made in proper unit, when it feels that more good she is taken care of it in the PSF for being carrying of the HIV, she has bond with the professionals of the PSF as if they were familiar, they trust the professionals of the PSF, feel that the professionals do not feel penalty. And, she does not disclose when the inadequate attitude of the professional generated fear and unreliability when it communicated to the user the diagnosis, they find that the PSF is on to the care of people with serious illnesses and bedridden, do not trust 
these professionals of in addition the secrecy from fear, and already they all possess has a support in SAE.

Descriptors: aids, woman's health, confidentiality 


\section{SUMÁRIO}

$\begin{array}{ll}\text { APRESENTAÇÃO } & 11\end{array}$

1. INTRODUÇÃOO 13

1.1. Panorama atual da epidemia de Aids das mulheres no Brasil e no 13 Município de São Paulo

1.2 A assistência aos portadores de HIV/AIDS no Município de São Paulo 18

2. OBJETIVOS 28

3. CAMINHO METODOLÓGICO 29

$\begin{array}{ll}3.1 \text { Referencial Teórico } & 29\end{array}$

$\begin{array}{ll}3.2 \text { Cenário do estudo } & 37\end{array}$

$\begin{array}{ll}3.3 \text { Sujeitos da pesquisa } & 38\end{array}$

$\begin{array}{ll}3.4 \text { Coleta de dados } & 39\end{array}$

$\begin{array}{ll}3.5 \text { Instrumento de coleta dos dados } & 40\end{array}$

3.6 Organização dos dados para análise $\quad 41$

3.7 Aspectos éticos da pesquisa 43

4. RESULTADOS E DISCUSSÃO 44

4.1 Caracterização das mulheres entrevistadas 44

4.2 Compartilhando o segredo do diagnóstico de HIV com familiares, $\quad 50$ amigos e vizinhos

4.3 Compartilhando o segredo do diagnóstico com os profissionais do $\quad 73$

PSF: a abertura (ou não) do diagnóstico de HIV/AIDS

5. CONSIDERAÇÕES FINAIS

6. REFERÊNCIAS BIBLIOGRÁFICAS 90

APÊNDICE

$\begin{array}{ll}\text { ANEXOS } & 153\end{array}$ 


\section{APRESENTAÇÃO}

A motivação para a realização deste estudo partiu da minha experiência enquanto aluna de graduação de enfermagem da Escola de Enfermagem da Universidade de São Paulo, durante o período de estágio curricular, no ano de 2004.

Durante as atividades realizadas pela equipe de saúde junto à comunidade, chamou-me a atenção a proximidade existente entre esta e o Programa Saúde da Família, em especial, a vivência dos Agentes Comunitários de Saúde (ACS). Exemplo disto foi uma situação na qual existia preocupação da equipe em manter o sigilo das informações de uma mulher infectada pelo HIV/AIDS, especialmente por ser uma doença estigmatizante.

A assistência aos portadores do HIV/AIDS é realizada pelas equipes quando estas conhecem o diagnóstico de soropositividade ao HIV de algum membro da família. A informação sobre o diagnóstico passa a ser de conhecimento da equipe quando este foi realizado por ela ou quando a usuária revela à equipe sua condição de portadora.

Dessa forma, se a usuária não abre a privacidade de suas informações sobre o diagnóstico à equipe do PSF, a realização da assistência voltada às especificidades das mulheres infectadas pelo HIV/AIDS fica comprometida. Por outro lado, a revelação de algo que lhes é privativo pode trazer conseqüências positivas ou negativas à vida das mulheres, principalmente, no que diz respeito aos medos de sofrerem com estigmas e preconceitos que envolvem o viver soropositiva ao HIV 
em uma determinada comunidade. Na medida em que se abre a privacidade das informações é necessário que a equipe mantenha o sigilo destas.

Indaga-se no presente estudo quais são as condições que levam as mulheres infectadas pelo HIV/AIDS a abrir a privacidade de suas informações à equipe de PSF. 


\section{INTRODUÇÃO}

\subsection{Panorama atual da epidemia de Aids das mulheres no Brasil e no Município de São Paulo}

No Brasil, a epidemia de aids torna-se visível em 1980 e, a partir de então, foram notificados progressivamente novos casos da doença. Tem-se em 1993, 71259 casos e nos cinco anos subseqüentes o aumento de pessoas infectadas foi substancial, chegando em 1998 ao montante de 200786 casos notificados. (Brasil, 2006)

As recentes estatísticas contabilizam 433067 indivíduos portadores do HIV/AIDS de 1980 a 30 de julho de 2006. Observa-se que vem ocorrendo estabilização da incidência a partir de 2000, embora ainda elevada, ao atingir 18,0 por 100000 habitantes em 2006, basicamente devido à persistência no crescimento do número de casos no segmento feminino, até 2004, e sua lenta diminuição posterior. (Brasil, 2006).

Embora proporcionalmente haja um número maior de casos em homens do que em mulheres, a notificação feminina vem aumentando. Em 1984, foram notificados 36 homens para cada duas mulheres, dessa forma, a razão entre os sexos masculino/feminino (M/F) foi de 18,1. A tal ponto que em 1997 a razão M/F chegou a 2,0 e em 2003 atingiu 1,5. Dados preliminares do ano de 2006, apontam para a razão de 1,4. Este processo aqui destacado é identificado como feminização da epidemia. (Brasil, 2006).

O processo de feminização é um fenômeno mundial. Análise dos dados epidemiológicos indica que dentre os 36,6 milhões de adultos infectados, $42 \%$ são do 
sexo feminino, sendo que sua participação na epidemia vem aumentando progressivamente (World Health Organization- WHO, 2001).

No Brasil, até o ano de 2006, foram notificados 142.138 casos de aids em mulheres. As maiores taxas de incidência, no ano de 2006, estão concentradas nas faixas etárias que compreendem as mulheres de 25 a 49 anos, variando de 10,6 a 13,4 por 100.000 habitantes. A categoria de exposição hierarquizada predominante, neste ano, para as mulheres foi a categoria heterossexual com 93,3\%, seguida de uso de drogas injetáveis com 4,7\% e transfusão sanguínea com $0,3 \%$.

O estado de São Paulo é o estado brasileiro com maior número de notificações de aids, cerca de $38,6 \%$ do total de notificações realizadas até 30 de junho de 2006 no Brasil. E dentro do estado de São Paulo é o município de São Paulo aquele com maior número de casos, cerca de $41,6 \%$ das notificações, no mesmo período, em relação aos demais municípios (Brasil ,2006; São Paulo, 2006).

No município de São Paulo, até dezembro de 2004, 14.955 mulheres maiores de 13 anos haviam sido notificadas com aids, 88,0\% tiveram como categoria hierarquizada de exposição a via heterossexual. O coeficiente de incidência de aids entre as mulheres em 2004 foi de 13,9 por 100.000 habitantes e a razão de sexo M/F foi de 1,9 para o mesmo ano (São Paulo, 2005).

Em 2004, excetuando-se 20,1\% dos dados sem a informação sobre a categoria de exposição, 76,3\% das mulheres maiores de 13 anos tiveram exposição ao vírus em relações heterossexuais, seguida de uso de drogas injetáveis $(3,1 \%)$. Verifica-se que, neste período, a maioria das mulheres possuía até sete anos de estudo.(São Paulo, 2005). Quanto à ocupação das mulheres com aids, de 2001 a 2003, foram donas de casa aquelas que figuraram em primeiro lugar dentre todas. (São Paulo, 2004). 
Observa-se que até 1990 a curva de crescimento da aids foi ascendente, passando a partir de então a diminuir sua velocidade, no entanto, diferentemente dos homens, entre as mulheres ela foi bem menor. A aids chegou a figurar como primeira causa de morte entre mulheres jovens (20 a 34 anos), de 1991 a 1998 no município de São Paulo. (Santos et al, 2002).

A mortalidade no município vem apresentando uma queda acentuada a partir de 1996, sendo o uso de anti-retrovirais um dos principais fatores associados a esta diminuição, além da descentralização do atendimento, que possibilita um diagnóstico mais precoce e a intervenção adequada sobre as infecções oportunistas, o que altera consideravelmente a sobrevida dos pacientes e desta forma os portadores de HIV/AIDS tiveram ampliadas, não apenas sua expectativa de vida, como também a qualidade de vida. De fato, nos dois últimos anos, essa queda está apresentando uma visível desaceleração (São Paulo, 2003).

Falando especificamente dos anti-retrovirais de acordo com Reyes (1996), o início da quimioterapia moderna da infecção por HIV tem semelhança com a quimioterapia anti-neoplásica (combinada e prolongada) e trouxe boas possibilidades de transformação da doença aids em patologia crônica ou pelo menos de patologia de sobrevida prolongada e com boa qualidade de vida. Para além dos benefícios que a terapia com anti-retrovirais trouxe, são diversas as condições capazes de influenciar a qualidade e o tempo de vida das pessoas infectadas pelo HIV/AIDS.

Segundo analisa Santos et al (2002), o acompanhamento laboratorial e o manejo clínico cuidadoso e adequado das pessoas infectadas pelo HIV por clínicos treinados e eficientes, a quimioprofilaxia e tratamento de determinadas infecções oportunistas que aumentam o risco de morte, a compreensão dos fatores 
constitucionais e o acompanhamento psicológico dos pacientes são todos aspectos fundamentais a serem considerados, sem os quais, a administração pura e simples da terapêutica anti-retroviral não é suficiente para mudar o prognóstico da infecção pelo HIV.

É necessário considerar que nas mulheres o processo saúde-doença na condição de infecção pelo HIV possui particularidades que as distinguem dos homens. (Xavier, 1996). Nas mulheres, determinantes biológicos e sociais favorecem a transmissão do HIV e o desenvolvimento para a doença e, portanto, a sua sobrevida.

Na questão da transmissão do HIV, nas mulheres destacam-se as diferenças anatômicas, a maior concentração do HIV no sêmen do que na mucosa vaginal, a ocorrência de micro-lesões na mucosa vaginal durante a relação sexual (em área extensa do canal vaginal), a diminuição da lubrificação da vagina (variável conforme a idade e o estímulo sexual) e a utilização de contraceptivos que criam um ambiente favorável à penetração do vírus. Destacam-se ainda, o estágio da doença, a presença de outras doenças sexualmente transmissíveis, inflamações ou irritações na mucosa vaginal, a natureza e a frequiência das relações sexuais (número de parceiros, a atividade sexual desprotegida durante a menstruação etc.), a desigualdade social, questões relacionadas ao gênero, a pobreza, e a falta de percepção de risco à infecção, principalmente em mulheres que vivenciam relacionamentos estáveis (García-Sanchez, 2004; Villela, 1996).

Outro fator determinante na história do HIV/AIDS em mulheres foi o fato de que com a imagem da mulher-mãe-esposa que se tinha, e a divulgação dos chamados grupos de risco, fazer com que estas mulheres se sentissem protegidas do "mal" da aids, tal visão possibilitou que a partir da década de 1980 houvesse uma rápida e 
silenciosa disseminação do vírus HIV entre as mulheres, principalmente entre as mulheres com relacionamentos estáveis (Vermelho et al, 1999).

Vale lembrar que o papel de "cuidadora" exercido pelas mulheres na sociedade faz com que haja a eleição da família e dos filhos como prioridade no cuidado, muitas vezes trazendo como conseqüência desde a não percepção do risco para o HIV/AIDS, como o descuido em relação ao seu próprio cuidado (Santos et al, 2002a)

Com isso a necessidade de se considerar as especificidades femininas nas ações de enfrentamento da epidemia da aids vem esbarrando nessas ideologias, que dificultam e inviabilizam as estratégias adequadas de prevenção e de atenção às mulheres infectadas pelo HIV/AIDS (Aguiar e Simões-Barbosa, 2006).

Por ter estas características, devem-se realizar estudos sobre a aids e suas implicações no grupo de mulheres, como corroborado por Garcia-Sanchez (2004) quando afirma que não se deve estender os resultados de estudos realizados com homens para orientação de intervenções em mulheres. E que há necessidade de se desenvolver estudos que permitam o conhecimento das dificuldades e barreiras adicionais que as mulheres enfrentam direta ou indiretamente pelo HIV/AIDS. Esse conhecimento se torna essencial, tanto para a provisão de serviços e tratamento, quanto para o desenvolvimento de programas no âmbito da prevenção. 


\subsection{A assistência aos portadores de HIV/AIDS no Município de São Paulo}

Para entender a forma como hoje está organizada a rede de atenção ao HIV/AIDS no Município de São Paulo, será necessário olhar a história de sua constituição.

Contextualizando o período histórico em que surgem as primeiras iniciativas em torno da resposta à epidemia de HIV/AIDS, é importante lembrar que neste momento a sociedade brasileira se rearticulava politicamente. Na esteira de uma crise econômica que lhe minava cada vez mais a legitimidade, o regime militar abrandava progressivamente seu controle sobre o processo político, e organizações da sociedade civil começavam a emergir e ocupar espaços.

Entre estes grupos, em particular, encontravam-se representantes de setores organizados da sociedade e também profissionais de saúde empenhados num redesenho da assistência pública à saúde, no que ficou conhecido como movimento de Reforma Sanitária. Um exemplo de participação de grupos organizados na discussão sobre a política de saúde se deu na questão do HIV/AIDS. A cooperação estabelecida entre membros da comunidade de homossexuais e técnicos da Secretaria Estadual da Saúde de São Paulo foi determinante para o estabelecimento das primeiras ações em torno da epidemia no estado de São Paulo e no Brasil (Guerra, 1993).

As ações voltadas à questão da aids no país datam de 1983 , no âmbito da Secretaria Estadual da Saúde de São Paulo. Estas diziam respeito à organização, coordenação e estruturação das atividades de diagnóstico, controle e orientações em relação ao agravo; estabelecimento da vigilância epidemiológica e divulgação das 
informações. Foi a partir das iniciativas do estado de São Paulo, em 1986, que se estruturou o Programa Nacional de DST/AIDS, no mesmo ano em que ocorreu a VIII Conferência Nacional de Saúde, marco histórico de redemocratização no país, que culminou na Constituição Brasileira e na criação do Sistema Único de Saúde (SUS).

O SUS, que tem como princípios a universalidade, a eqüidade, a integralidade, a descentralização e o controle social, propõe que as unidades de saúde sejam capazes de dar atenção integral à saúde dos cidadãos. No entanto, neste momento de criação e construção do SUS, as ações de prevenção e controle do HIV/AIDS ainda eram tratadas de forma bastante centralizadas, com forte direcionamento da Secretaria de Estado e com praticamente nenhuma participação dos municípios. Praticamente respondiam pelo atendimento da demanda de doentes de aids no estado o Centro de Referência e Treinamento em DST/AIDS, criado em 1983, e o Instituto de Infectologia Emílio Ribas, equipamentos de saúde da Secretaria de Estado, localizados no município de São Paulo (Guerra, 1993).

Segundo Parker (1997), após o período de centralização, passa-se a um período crítico, quando as ações assistenciais de prevenção e mesmo de vigilância epidemiológica não acompanhavam a progressão da epidemia. A aids já se expandia progressivamente para os municípios do interior e nos diferentes grupos populacionais. Por intermédio do Centro de Referência e Treinamento em DST/AIDS procurou-se então estruturar uma resposta mais condizente com a dimensão do problema, entre outras coisas, estendendo as ações para outras cidades do estado.

Dessa forma, os municípios passaram a organizar a rede de atenção ao HIV/AIDS nos seus territórios de abrangência. Desta forma, de 1983 a 1988 houve 
importante expansão, descentralização e consolidação das ações programáticas voltadas à prevenção e ao controle da aids no estado.

No âmbito do município de São Paulo, a discussão para implantação das ações programáticas iniciou-se por volta de 1987, concretizando o Programa Municipal de Prevenção e Controle de DST/AIDS. Como primeiras iniciativas, criaram-se em 1989 o Centro de Testagem e Aconselhamento (CTA), o CTA Henfil, na região central da cidade e o Centro de Referência de DST/AIDS Herbert de Souza, o Centro de Referência Betinho, em Sapopemba, zona leste da cidade (São Paulo, 2003).

No período de 1993 a 2000, passaram a totalizar 23 unidades de saúde voltadas à questão do HIV/AIDS, sendo cinco COAS, $15 \mathrm{CR}$ (que levavam esse nome, mas exerciam a função real de ambulatórios especializados em DST/AIDS) e três laboratórios especializados (Mesquita e Turienzo; 2003).

O CTA fornece informações, aconselhamento, diagnóstico da infecção pelo HIV oferecendo, de forma anônima e sigilosa, à população em geral e a grupos vulneráveis. Já as unidades assistenciais Centro de Referência (CR), Serviço de Assistência Especializada (SAE) e Ambulatórios de Especialidades (AE) se distinguem pelo seu grau de complexidade e têm como finalidade acolher pessoas infectadas pelo HIV/AIDS que necessitam de atendimento ambulatorial ou internação-dia para uso de medicação específica, em regime de hospital-dia. Há ainda neste serviço a modalidade de atendimento domiciliar terapêutico e ações de prevenção.

A consolidação do Programa Municipal deve ser entendida dentro do contexto mais amplo da vida política na cidade. Este período de ampliação dos serviços de saúde voltados ao HIV/AIDS corresponde ao período no qual houve uma mudança 
estrutural de toda a rede de assistência à saúde geral realizada pelo serviço público municipal, com a implantação do Plano de Assistência à Saúde (PAS), de 1993 a 2000. O PAS era pautado na ênfase assistencial e executado por um grupo de cooperativas privadas pagas através de recursos públicos, sem comprometimento com a manutenção dos serviços de Saúde Pública (São Paulo, 2003). As unidades básicas passaram a atender à semelhança de prontos-atendimentos, tendo como característica o financiamento dos serviços per capita. As consultas médicas foram privilegiadas, em detrimento de atividades realizadas por outros profissionais, como ações de prevenção de doenças e promoção da saúde, levando à desvalorização de muitas atividades programáticas, como a atenção aos portadores de hanseníase, tuberculose e aids. (Guerra, 1993).

Na implementação do PAS, os serviços de DST/AIDS permaneceram na administração direta da Secretaria Municipal (São Paulo, 2003). Embora isolados da política oficial, segundo analisa Mesquita e Turienzo (2003), paradoxalmente houve uma ampliação no número de serviços de diagnóstico e assistência ao HIV/AIDS. Os autores entendem que esta expansão se deu devido à captação de recursos do Banco Mundial, repassados à Coordenação Nacional de DST/AIDS e à Secretaria Municipal de Saúde de São Paulo. Além disso, outros fatores que podem explicar são a disponibilidade de locais pra o atendimento de DST/AIDS, dado que o PAS não os assumiu em sua prioridade de atendimento, e o grande contingente de profissionais, funcionários da Secretaria Municipal que não aderiram ao PAS e que passaram a se envolver com o atendimento aos portadores de HIV/AIDS.

Atualmente, a rede municipal conta com nove centros de testagem e aconselhamento (CTA), 15 unidades de referência, serviços de assistência 
especializada (SAE) ou ambulatório de especialidades (AE) e três laboratórios de saúde pública especializados em DST/AIDS.

Nestes serviços, integrados ao SUS, estão disponíveis testes sorológicos, consultas, orientações de prevenção e tratamento às DST como, por exemplo, sífilis, cândida, gonorréia, HPV, HIV/AIDS e hepatites (Prefeitura do Município de São Paulo, 2004).

Em virtude da complexidade que o tratamento da aids requer, o acompanhamento das pessoas infectadas, doentes ou não, deve ocorrer ao nível dos ambulatórios especializados. Praticamente até 1993 a prevenção da infecção pelo HIV e a assistência aos portadores eram realizadas por esses serviços. Somente a partir deste ano, o Programa Municipal iniciou um processo de ampliação de suas ações, inicialmente sensibilizando e capacitando os trabalhadores da atenção básica, com vistas à realização descentralizada de ações voltadas ao diagnóstico precoce da infecção e encaminhamento dos portadores para os demais níveis de assistência (Gryschek, 2001).

No âmbito da atenção básica, a prioridade em relação às ações voltadas ao HIV/AIDS é a identificação de grupos vulneráveis, oferecimento de testagem sorológica para detecção do vírus e realização de ações de promoção da saúde e prevenção da doença. No atendimento aos portadores do HIV requer-se articulação dos vários serviços do SUS no desenvolvimento de um trabalho integrado por um sistema de referência e contra-referência, dos serviços especializados com as unidades básicas de saúde.

A rede básica, porta de entrada do Sistema de Saúde, para ser resolutiva deve estar capacitada, no seu nível de competência, a realizar o diagnóstico de saúde local, 
identificando e priorizando os problemas detectados, buscando intervir em parceria com a comunidade e demais setores sociais e institucionais. Diante das tendências apresentadas pela epidemia, sua magnitude na população em geral, a rede básica de assistência deve possibilitar a realização de ações de acolhimento, tratamento e/ ou encaminhamento das pessoas infectadas pelo HIV, além de identificar populações/ usuários de maior vulnerabilidade (São Paulo, 2003).

Na atenção básica, como diretriz privilegiada, o Ministério da Saúde (MS) criou em 1994 o Programa Saúde da Família (PSF) que possibilita integração e organização das ações de saúde em território definido, cuja finalidade é propiciar o enfrentamento e a resolução de problemas identificados, pela articulação de saberes e práticas com diferenciados graus de complexidade tecnológica, integrando distintos campos de conhecimento e desenvolvendo habilidades e mudanças de atitudes nos profissionais envolvidos (São Paulo, 2003).

O PSF é uma estratégia em que podem ser intensificadas as ações de promoção da saúde e prevenção do HIV, ao mesmo tempo que reforça junto às pessoas infectadas seus direitos humanos e civis, garantindo melhor qualidade de vida (São Paulo, 2003).

O PSF assume um conceito ampliado de atenção básica, que avança em direção a um sistema de saúde integrado convergindo para a qualidade de vida das pessoas e de seu ambiente (Zoboli e Fortes, 2004).

A reorganização da atenção básica pela estratégia do PSF amplia e aprofunda a reviravolta ética trazida pelo SUS, pois sua efetivação não se resume a uma nova configuração da equipe tecno-assistencial, mas a um novo processo de trabalho 
marcado por uma prática ética, humana e vinculado ao exercício da cidadania (Zoboli e Fortes, 2004).

É primordial que o PSF realize uma ação integrada com os serviços de referência em HIV/AIDS para intensificação do acompanhamento dos indivíduos infectados. A colaboração entre os serviços de saúde ajuda a assegurar uma assistência contínua, desta forma os indivíduos serão acompanhados em todos os estágios da infecção da prevenção ao tratamento (Silva et al, 2005).

Tendo como aspectos fundamentais a adscrição da população a um dado território, o trabalho em equipe multiprofissional e a incorporação um novo trabalhador, o agente comunitário de saúde (ACS), o PSF vive o desafio de estabelecer novas relações no tocante às informações pessoais sobre a saúde dos indivíduos e suas famílias, garantindo a privacidade daqueles com quem a equipe se relaciona na comunidade.

Sobre o ACS, Fortes e Spinetti (2004) destacam que possui uma situação singular, uma vez que deve obrigatoriamente residir na área de atuação da equipe e exercer a função de elo de ligação entre a equipe e a comunidade, o que pode fazer com que viva o cotidiano da comunidade com maior intensidade do que os outros membros da equipe de saúde. A presença do ACS como elemento na equipe de saúde da família traz contribuição fundamental nas relações com os usuários do sistema público de saúde.

Os autores consideram que por ter o ACS maior proximidade com o usuário, por habitar o mesmo bairro, e ainda, por adentrar freqüentemente o domicílio das famílias, haja maior facilidade na disseminação de informações, até mesmo as sigilosas. Os autores analisam que tal fato traz implicações éticas no que diz respeito 
à privacidade das informações e a autonomia dos usuários (que engloba a intimidade, a vida privada e a honra das pessoas), principalmente no que tange o acesso a determinadas informações pessoais que possam trazer algum grau de discriminação e/ou estigmatização negativa para os usuários, como por exemplo, de pessoas infectadas pelo HIV/AIDS.

Os autores consideram que são os próprios usuários que têm direito de decidir que a informação sobre sua soropositividade seja mantida sob seu controle, a quem, quando, onde e em que condições as informações pessoais devem ser reveladas (Fortes, Spinetti, 2004).

Os conflitos existentes na manutenção do direito à privacidade e no exercício do dever do sigilo pelos profissionais são objetos do presente estudo. Os estudos que tratam dessa temática têm focado, principalmente, a relação profissional-usuário mais voltada à esfera de atendimento hospitalar e são poucos os estudos que tratam da relação HIV/AIDS e PSF (Zobolli, 2003).

A bioética, no contexto internacional e brasileiro, tem deixado de lado as questões de Saúde Pública e de Saúde Coletiva, dedicando-se muito mais à reflexão e discussão dos problemas de ordem ética enfrentados pelos profissionais de saúde que atuam nos hospitais e outros serviços de saúde que concentram a incorporação de alta tecnologia. Dessa forma, os estudos acabam negligenciando a rede básica de saúde, principalmente as unidades básicas de saúde e serviços de baixa complexidade (Zoboli, 2003).

Segundo Zoboli (2003), os problemas éticos enfrentados na atenção básica devem diferir dos identificados nas demais esferas de atendimento. A autora considera quatro pontos fundamentais na análise. Em primeiro lugar, destaca que os 
problemas de saúde encontrados nos diversos serviços de assistência se diferenciam de acordo com o nível das ações e dos procedimentos oferecidos e prestados, desta forma, há que considerar as especificidades da assistência na atenção básica. Em segundo lugar, considera que os sujeitos éticos, isto é, os usuários, os familiares e os profissionais de saúde também são diferentes.

A autora explica que os usuários de um serviço de saúde hospitalar, pela própria condição da internação, estão com sua autonomia mais comprometida do que os não hospitalizados. Os profissionais de saúde, na atenção básica, usualmente buscam objetivos de longo prazo, como por exemplo, a transformação dos perfis epidemiológicos da coletividade a partir da atenção integral e não somente o tratamento de um problema pontual.

Em terceiro lugar, Zoboli (2003) destaca que o cenário difere em cada serviço de saúde e isto tem importância na medida em que os problemas de ordem ética emergem do contexto no qual se inserem. Julga que nas unidades básicas de saúde, os encontros entre os profissionais de saúde e os usuários são mais freqüentes e em situações de menor urgência. Assim, segundo analisa, a emergência, o imediatismo e a dramaticidade das situações vivenciadas, por exemplo, nos prontos-socorros fazem com que os problemas éticos sejam freqüentemente mais evidentes, tempestuosos e conturbados, enquanto nas unidades básicas de saúde apresentam-se de maneira mais sutil, passando, na maioria das vezes, despercebidos.

Considerado isto, e por último, as soluções buscadas para a resolução dos problemas éticos podem diferir nos diversos serviços de atenção à saúde, porque mesmo que se observe uma estrutura similar do raciocínio ético, os sujeitos éticos e o contexto são distintos. 
Concorda-se com Pinheiro et al. (2005) quando aponta que a ética tem que ser inserida no cotidiano, norteando as atividades de assistência aos infectados pelo HIV/AIDS e, também, no ensino e na pesquisa. Porque somente com consciência ética se fazem pessoas e trabalhadores melhores.

Diante do exposto, foi problematizado em que condições as mulheres infectadas pelo HIV abrem a privacidade de suas informações às equipes de PSF, formulando-se algumas hipóteses, são elas:

? A mulher tem medo do estigma e preconceito que possa sofrer ao revelar sua soropositividade à equipe de PSF;

? A mulher não vê necessidade de falar à equipe de PSF, pois acha que já tem todo o suporte necessário no Centro de Referência em que é acompanhada;

? A mulher desconhece o que o PSF pode lhe oferecer em termos de assistência;

? A mulher tem receio de que haja invasão da sua privacidade e perda de sua autonomia ao revelar o diagnóstico à equipe.

O presente estudo elege como finalidade oferecer subsídios para a melhoria da qualidade da assistência às mulheres soropositivas ao HIV/AIDS atendidas no PSF. 


\section{OBJETIVOS}

? Descrever as condições em que mulheres infectadas pelo HIV abrem a sua privacidade em relação à informação sobre o diagnóstico de soropositividade a familiares, amigos e vizinhos.

? Identificar quais as motivações para abrir a privacidade de suas informações para a equipe de PSF das mulheres soropositivas ao HIV/AIDS. 


\section{CAMINHO METODOLÓGICO}

\subsection{Referencial teórico}

As questões que envolvem a privacidade e a confidencialidade foram aqui tratadas no campo da bioética.

O termo Bioética é sugerido por Van Rossenlaer Potter em 1970, em uma palestra intitulada "Ponte para o futuro, um conceito do progresso humano", realizada na Universidade de Dakota do Sul, que foi publicada no mesmo ano. Em janeiro de 1971, publica um livro sobre o mesmo tema, que se torna conhecido do público em geral através da reportagem publicada pela Revista Time, em 19 de abril de 1971 (Potter, 1998).

Potter, depois de procurar por palavras que pudessem expressar o equilíbrio entre a orientação científica da biologia com os valores humanos, chegou ao termo, que une os conhecimentos da biologia e os da ética. Segundo Zoboli (2003), seu intuito era "ajudar a humanidade em direção a uma participação racional, mas cautelosa, no processo da evolução biológica e cultural” (Zoboli, 2006 a).

Situando historicamente os dilemas éticos que ajudaram no processo de repensar as práticas vigentes até a década de 1970, relembramos que nas décadas de 1960 e 1970, a biomedicina experimenta um grande avanço tecnológico, com terapias de alta tecnologia e alto custo. Com o evento da diálise em 1962, em Seatle (EUA), instituiu-se um comitê que deveria escolher quem deveria ter acesso a este novo recurso terapêutico bem como, o transplante de órgãos, o advento do diagnóstico pré-natal de algumas patologias aliado à possibilidade de aborto, a 
revolução da engenharia genética entre outras. Somados a esses dilemas, surgem as denúncias feitas por Beccher em artigo publicado no New England Journal of Medicine, em 1966, de 22 pesquisas eticamente incorretas realizadas com seres humanos, mesmo após o desenvolvimento do código de Nürenberg, em 1947, e a Declaração de Helsinque, em 1964. Tais fatos, além de escandalizarem a opinião pública, colocaram em questionamento a medicina e a ética.

Na segunda edição da Enciclopédia de bioética (Reich, 1995), o termo bioética é definido como: “o estudo sistemático das dimensões morais, incluindo a visão, a decisão, a conduta e as normas, das ciências da vida e da saúde, utilizando uma variedade de metodologias éticas num contexto interdisciplinar. "

A partir de tal definição é possível verificar que existem diferentes tendências na configuração das formas de sistematizar e tratar a análise teórica em bioética, não sendo balizada em um único método ou uma única forma de análise, admitindo assim, o uso interdisciplinar.

Bioética, no sentido amplo de ética da vida, aproxima a raiz bios, que diz respeito não só à biologia, mas a todas as ciências da vida, tais como, ecologia, medicina, enfermagem, ciências sociais e outras, com ethos, que diz respeito aos valores implicados nos conflitos da vida (Gracia, 1998; Pessine, 2000).

Zoboli (2003; 2006 a) aponta que bioética é uma nova maneira de tratar a ética nas ciências da vida e da saúde, combinando "estudo e reflexão e traçando uma ponte entre as ciências biológicas e as humanas mediante um diálogo inclusivo, plural e responsável na busca da sabedoria, entendida como a compreensão de como usar o conhecimento para o bem social e para a promoção da dignidade humana e da boa qualidade de vida". 
A partir dos anos 80, a bioética começa a ampliar seu foco de visão situando a relação clínica no contexto de um sistema de saúde e incorporando a reflexão de questões relativas à estrutura, à gestão e ao financiamento. Com a difusão da bioética, principalmente nos países pertencentes ao hemisfério sul, tornou-se imperativa a inclusão dos problemas da coletividade na agenda das discussões, com temas relativos ao acesso aos serviços de saúde e à alocação de recursos em saúde entre outras questões, já que configuram países que conjugam paradoxalmente ilhas de excelência tecnológica com extrema pobreza (Pessini e Barchfontaine, 2000 ).

A ética da saúde ocupa lugar de destaque no conjunto das reflexões éticas, justamente porque enfoca questões relacionadas à manutenção e à qualidade de vida das pessoas, fatos muito discutidos na atualidade (Zoboli, 2003)

A vertente principialista, também conhecida como principialismo, talvez seja a tendência da bioética mais difundida. É com a compreensão desta que se pode conhecer melhor a história da bioética, pois as demais teorias, em sua maioria, foram construídas a partir de um diálogo com esta, seja a corroborando ou a contradizendo. Por vezes, por essas características é chamada de "mantra da bioética" (Gracia, 1998).

O principialismo mostra-se atrativo para a prática da atenção à saúde, por propiciar uma linguagem simples, objetiva e que possibilita a expressão de percepções e sentimentos éticos, permitindo uma abordagem sistematizada de problemas da prática cotidiana (Pessini e Barchifontaine 1998).

O Enfoque Principialista da Bioética tem como protagonistas Tom Beauchamp e James Childress, que em 1979, na primeira edição da obra "Princípios da Ética Biomédica”, propõem quatro princípios orientadores para a análise de problemas 
éticos: a beneficência, a não-maleficência, justiça e a autonomia (Zoboli in Fortes e Zoboli, 2003). Elegemos o enfoque principialista para a discussão deste trabalho, utilizando o conceito de autonomia.

"A autonomia, do grego autós = eu e nomos = lei, é a capacidade especificamente humana de agir de acordo com sua vontade, diante de objetivos por ela estabelecidos" (Selli, 1998). "Autonomia é a capacidade de decidir por si mesmo nas questões que dizem respeito a si próprio, como indivíduo" (Selli,1998).

Do ponto de vista histórico, o conceito de autonomia individual possui uma longa evolução. Ocidentalmente, é no pensamento grego que se gesta a noção do indivíduo livre diante de laços sociais e políticos, capaz de agir de acordo com a sua vontade (Selli,1998).

O estabelecimento da autonomia na bioética conflitou com a visão tradicional, paternalista baseada no princípio da beneficência. Retomou a noção ética da igualdade entre o médico e o usuário dos serviços de saúde e estabeleceu as bases para garantias jurídicas do usuário diante do profissional da medicina e das instituições de saúde (Selli, 1998).

O princípio ético da autonomia preconiza que, quando o indivíduo tem condições de pensar, decidir e agir de modo livre e independente, é dele o direito de decidir, participar e consentir sobre as decisões que dizem respeito à sua pessoa.

Pessini e Barchifontaine (1996: 65), ao refletirem sobre a questão da autonomia, enfatizam que "o exercício da autonomia requer bom trato e cuidado, coisas que a comunicação e o diálogo podem fornecer, pelo fato de trazerem à tona todos os tipos de influências desconhecidas e consideradas sobre as escolhas a serem feitas". 
O diálogo entre o profissional de saúde e o usuário do serviço favorece o entendimento das razões e objeções do mesmo à maximização da autonomia (Selli, 1998).

"Experimentar a autonomia é também perceber a solidão existencial" (Schaurich e Padoin, 2004). "Ser autônomo é ter o direito de auto-determinar-se e de, simultaneamente, suportar que o outro faça o mesmo. Portanto, autonomia não se faz sem senso de reciprocidade" (Ferraz, 2006).

Deriva do princípio da autonomia, o direito a privacidade, que engloba a intimidade, a vida privada, a honra e a imagem da pessoa (Zoboli, 2004).

Etimologicamente a palavra "privacidade" origina-se do adjetivo "privatividade", ou seja, "o caráter do que é privativo, próprio de alguém, só dele, não público, reservado de foro íntimo”(Bueno, 1963).

A privacidade parte do princípio que a pessoa é autônoma para decidir a quem e como deseja permitir que seu corpo seja exposto para procedimentos médicos, diagnósticos e assistenciais ou quais informações a respeito de suas condições de saúde devem ser confidencializadas (Massarollo, Sacardo e Zoboli, 2006).

Allen (2005) distingue a privacidade, para efeitos didáticos, em três dimensões: privacidade física, privacidade de informações e privacidade decisional ou de decisão. Resumidamente, pode-se dizer que:

A privacidade física é o uso mais corriqueiro do termo, e 'denota liberdade de contato com outras pessoas', ou seja, a pessoa autônoma é quem decide com quem e como deseja estabelecer um contato. As demandas no cuidado com a saúde na modernidade pressupõem um contato muitas vezes íntimo, como a nudez, o toque e a 
observação entre os profissionais, especialmente os médicos e seus clientes para a realização de exames, tratamentos, cirurgia e hospitalização (Allen, 2005).

O segundo uso do conceito de privacidade proposto por Allen (1995) compreende como sendo 'sinônimo de segredo, confidência ou anonimato', requerendo limites de acesso às informações pessoais. Isto inclui informações extremamente modernas, como por exemplo, o código dos materiais genéticos de uma pessoa. Para a autora, a preservação da privacidade das informações é fundamental, pois afeta a qualidade da assistência à saúde.

O terceiro uso do conceito, ainda segundo Allen (1995), a privacidade decisional ou de decisão, 'denota escolhas autônomas sobre os assuntos pessoais e íntimos que constituem a vida privada'. No contexto da saúde, relaciona-se à responsabilidade para fazer escolhas quanto ao seu tratamento, levando em consideração suas expectativas, crenças e valores. Significa, assim a habilidade do paciente para tomar as próprias decisões e agir livre de interferências de outras pessoas, seja de médicos, profissionais da saúde, familiares ou amigos, portanto aproxima a privacidade do conceito de autonomia.

Neste trabalho será tomada a dimensão da privacidade relacionada ao acesso às informações de saúde pelos profissionais, uma vez que trata-se da abertura da privacidade, no sentido do conhecimento sobre a condição de soropositividade ao HIV de mulheres pela equipe do PSF.

Do indivíduo autônomo deriva a liberdade de guardar para si mesmo fatos pessoais que não deseja revelar aos outros (Reich,1995). Vale ressaltar que o que é privado e confidencial não é público. 
A garantia da privacidade requer a observação da confidencialidade das informações por parte dos profissionais de saúde e outros profissionais que por ventura venham a ter acesso a tais informações (Reich, 1995).

O fato de muitas pessoas do corpo médico, paramédico e administrativo terem que se interar de todos ou parte dos dados do paciente, não exime a todas elas de proteger a zona de confiança, que nos dias atuais encontra-se expandida, mas deve ser controlada, pois configura um fundamento tradicional e imutável na relação profissionais de saúde-paciente (Llano, 1991).

De acordo com Massarollo, Sacardo e Zoboli (2006), o "limite de acesso" às informações pessoais é dado pela pessoa autônoma, o conceito de privacidade das informações aparentemente se equivale ao de confidencialidade. No entanto, a confidencialidade diz respeito à responsabilidade dos profissionais em relação às pessoas que assistem. A privacidade se refere ao limite dado pelo usuário do serviço de saúde do que pode ou não ser compartilhado com outros (médicos, profissionais de saúde, familiares, seguradoras etc), portanto, a confidencialidade das informações traz ao profissional o dever ético e legal de resguardá-las.

Para que se estabeleça um "pacto" de confidencialidade é necessário que haja a abertura da privacidade por parte do usuário do serviço. A privacidade e a confidencialidade das informações são dois princípios distintos e complexos. Há correlação entre eles, uma vez que a privacidade consiste no conjunto de informações sobre uma pessoa, que pode decidir mantê-las sob seu exclusivo controle, ou comunicar, decidindo em que medida e a quem, quando, onde e em que condições o outro poderá acessar as informações. Já a confidencialidade se relaciona à garantia (no sentido de confiança) de que as informações confiadas não serão reveladas sem 
prévia autorização da pessoa em questão. Ou seja, a privacidade das informações é um direito dos usuários do serviço, ao mesmo tempo que a confidencialidade é um dever dos profissionais em relação às informações geradas e confiadas no relacionamento profissional-usuário (Massarollo, Sacardo e Zoboli, 2006).

Deve-se primar pelo princípio básico da manutenção da confidencialidade da informação que os profissionais de saúde possuem sobre um determinado usuário (segredo profissional) e respeitar que o diagnóstico e toda a informação pertinente à infecção pelo HIV pertençam ao paciente ou aos responsáveis legais em caso de incapacidade ou de menores de idade (Reyes, 1996).

Confidenciar consiste em revelar em segredo um dado pessoal. E confidente é a pessoa que, por amizade ou por qualidade humana, merece a confiança, desde que a mantenha, utilize, confiando um segredo (Llano, 1991).

Do direito à privacidade deriva o dever da manutenção do segredo por todos elementos da equipe, lembrando que são sigilosas não somente as informações reveladas confidencialmente, mas todas aquelas que a equipe de saúde descobre no exercício de sua atividade, mesmo havendo desconhecimento do usuário (Fortes apud Fortes e Spinetti, 2004).

Não se deve revelar uma confidência feita (como é o caso do segredo médico), prometida quando intervém uma promessa, oferecida ou pedida, de não revelar as notícias ou dados recebidos em confidência (Llano, 1991).

O segredo é o compromisso moral de não revelar as notícias conhecidas ou recebidas por via confidencial (Llano, 1991). 


\subsection{Cenário do estudo}

O estudo foi desenvolvido junto à Coordenadoria de Saúde Centro-Oeste da Secretaria Municipal de Saúde de São Paulo. Esta Coordenadoria compreende as Supervisões de Saúde do Butantã, Lapa/Pinheros e Sé/Santa Cecília. O presente estudo foi desenvolvido na Supervisão de Saúde do Butantã, localizada na Zona Oeste da cidade (Prefeitura do Município de São Paulo, 2006).

A Supervisão do Butantã é responsável por uma área de abrangência de 56,1 $\mathrm{Km}^{2}$ onde vivem 348.310 habitantes (IBGE, 2000). Congrega cinco distritos administrativos, o Butantã, o Morumbi, o Rio Pequeno, o Raposo Tavares e o Vila Sônia. Possui 14 Unidades Básicas de Saúde, sendo que quatro atuam com a estratégia do PSF (CSE Butantã, UBS São Jorge, Vila Dalva e Boa Vista) e um Serviço de Atendimento Especializado (SAE-Butantã), que atende DST/AIDS.

Dentre as demais Supervisões de Saúde (Lapa/Pinheiros e Sé/Santa Cecília), a Supervisão de Saúde do Butantã é a que possuía menor percentual de casos de aids notificados (13,6\%), totalizando de 1980 até julho de 2005, 1759 notificações. A taxa de incidência em 2004 era de 27,5 por 100 mil habitantes, ficando entre as duas outras Supervisões (Lapa/Pinheiros com 20,5 e Sé/Santa Cecília com 62,3 por 100 mil habitantes), maior que a do município de São Paulo, que era de 21,3 por 100 mil habitantes (São Paulo, 2005).

Na Supervisão do Butantã, as categorias de exposição principais identificadas, tanto em homens quanto em mulheres, de 1980 a 2005, é a heterossexual (36,0\%), seguida da homossexual masculina $(16,8 \%)$ e uso de drogas injetáveis $(15,9 \%)$. Este é um perfil diferente das demais Supervisões de Saúde da Coordenadoria Centro- 
Oeste, que têm como principais categorias, em primeiro lugar a homossexual masculina, seguida da heterossexual e depois pelo o uso de drogas injetáveis (São Paulo, 2005).

A razão entre os sexos no período de 1980 a 2005 na região do Butantã foi menor $(2,7)$ que o encontrada nas outras Supervisões de Saúde da Coordenadoria Centro-Oeste (5,6 para Sé/Santa Cecília Sé e 7,2 para Lapa/Pinheiros). Ou seja, há no Butantã número de notificações de casos em mulheres próximo ao número de homens, semelhante ao encontrado no município, cuja razão é 2,8. Entre as mulheres, a exposição se deve especialmente pela relação heterossexual, seguida pelo uso de drogas injetáveis (São Paulo, 2005).

\subsection{Sujeitos da pesquisa}

Fizeram parte do estudo mulheres portadoras do HIV/AIDS maiores de 18 anos, matriculadas e em acompanhamento no SAE-Butantã e que tivessem cadastramento em alguma equipe de PSF das Unidades Básicas de Saúde São Jorge, Vila Dalva, CSE Butantã ou Boa Vista.

A escolha de realizar a pesquisa no SAE e não nas unidades básicas de saúde deu-se porque a realização nas unidades básicas de saúde teria alcance apenas nos casos conhecidos pelas equipes de PSF, e no SAE seria possível encontrar mulheres que contaram e que não contaram ao PSF seu segredo do diagnóstico de soropositividade. Reunindo assim, em apenas um lugar, as mulheres que estão em acompanhamento no SAE e atendidas pelo PSF das unidades básicas de saúde 
indicadas. Também foi considerado o fato de que as usuárias estariam mais à vontade durante a realização das entrevistas no SAE, já que não se sentiriam prejudicadas de alguma forma no seu atendimento no PSF.

\subsection{Coleta dos dados}

Após a autorização pelo Programa Municipal de DST/AIDS e pela gerente do SAE Butantã, foi estabelecido contato com a interlocutora de pesquisa deste serviço para operacionalização da coleta de dados.

A interlocutora sugeriu que a identificação das usuárias se fizesse por meio dos prontuários, no entanto, dadas as dificuldades de localização dos endereços e telefones, optou-se por identificá-las no momento que comparecessem à unidade, procedimento realizado pelos funcionários da Unidade. Coube ao funcionário a sua identificação, segundo os critérios de inclusão e o convite para participação da pesquisa. Quando ocorreu o aceite para participação do estudo, foram agendados data e horário para realização da entrevista.

A interlocutora teve papel fundamental no processo de efetivação da coleta de dados, sendo o elo de ligação entre as usuárias convidadas a participarem da pesquisa e a marcação das entrevistas, uma vez que não foi permitido que a pesquisadora abordasse as usuárias antes do aceite (ou não).

Como estratégia de sensibilização dos trabalhadores para identificação de mulheres com o perfil necessário, realizou-se uma reunião de apresentação da pesquisa, com a presença da diretora da unidade e demais funcionários - psicólogas, 
educadoras em saúde, assistentes sociais, enfermeiras e médicos. Além disso, distribuíram-se filipetas de aviso lembrando os critérios de inclusão no estudo, além da fixação das mesmas em quadros de avisos.

Foram agendadas oito entrevistas, sendo que duas usuárias não compareceram e uma delas teve sua entrevista remarcada. Uma das entrevistas foi descartada por não se encaixar nos critérios de inclusão do estudo. Portanto, chegouse a um total de seis entrevistas, realizadas no período de 12 de maio a 04 de julho de 2006.

Os dados foram coletados por meio de entrevistas gravadas, realizadas em um único encontro. Utilizou-se um roteiro semi-estruturado (Anexo 1). As entrevistas foram realizadas numa sala privativa, com duração de aproximadamente 40 minutos, foram transcritas por uma profissional experiente e revisadas pela pesquisadora.

\subsection{Instrumento de coleta dos dados}

$\mathrm{O}$ roteiro de entrevista está dividido em duas partes. A primeira refere-se à caracterização da mulher em relação à data de nascimento, anos completos de estudo, escolaridade, situação de emprego, número de filhos residentes com a entrevistada, idade dos filhos, pessoas que residem na mesma casa, renda total da casa, participação em associações, igreja, centro comunitário ou ONG, tempo de moradia no bairro e tempo de conhecimento do diagnóstico de soropositividade ao HIV.

A segunda parte do roteiro explora as condições em que a entrevistada ficou sabendo do diagnóstico de infecção pelo HIV; com quem ela compartilhou o 
conhecimento sobre o seu diagnóstico pela primeira vez e depois com quais outras pessoas dividiu a informação e como vivenciou esta situação. Além disso, explorouse a relação da entrevistada com a comunidade em que mora, indagando se o fato de ser soropositiva interferia na sua convivência com familiares e vizinhos e, por fim, em que condições a equipe do PSF tomou conhecimento sobre o seu diagnóstico.

\subsection{Organização dos dados para análise}

Trata-se de um estudo descritivo de natureza qualitativa. Os dados foram organizados pela Análise de Conteúdo, segundo Bardin (1977).

Bardin (1977) define o método da análise de conteúdo como

"um conjunto de técnicas de análise das comunicações visando obter, por procedimentos sistemáticos e objetivos de descrição de conteúdo das mensagens indicadores (quantitativos ou não) que permitem a inferência de conhecimentos relativos às condições de produção/recepção (variáveis inferidas) destas mensagens".

Por se tratar de um conjunto de técnicas de análise das comunicações, a análise de conteúdo possui um vasto campo de aplicação. Presta-se a ser utilizada a qualquer transporte de significado de um emissor para um receptor controlado ou não, podendo ser transcrito e decifrado (Bardin, 1977).

O método de análise de conteúdo é composto por três fases: a pré-análise, a exploração do material, o tratamento dos resultados e a interpretação.

A pré-análise compreende a fase de preparação do conteúdo do discurso ou depoimentos propriamente dita. Realiza-se uma leitura flutuante do material a ser 
analisado. O pesquisador deve deixar-se invadir por impressões e orientações (Bardin, 1977).

A exploração do material compreende uma fase longa e cansativa. Consiste essencialmente na reunião de um grande número de unidades temáticas e o agrupamento por meio do processo de categorização. A análise temática presta-se a descobrir núcleos de sentido que compõem as entrevistas, cuja presença ou freqüência de aparição podem significar alguma coisa para o objetivo analítico envolvido (Bardin,1977).

Bardin (1977) define tema como uma unidade de registro que corresponde a uma regra de recorte de sentido e não da forma. Aponta que tal regra não é fornecida a priori, pois o recorte depende do nível de análise utilizado pelo pesquisador e não de manifestações formais reguladoras.

Dessa maneira, após as entrevistas, os conteúdos dos depoimentos das mulheres resultou na obtenção de textos, que após decomposição conformaram num conjunto de subtemas, que agrupados constituíram as categorias empíricas "compartilhando o segredo aos outros" e "compartilhando o segredo aos profissionais de saúde", que sintetizam as condições e as motivações que levam as mulheres entrevistadas a revelar o diagnóstico de soropositividade ao HIV. 


\subsection{Aspectos éticos da pesquisa}

O projeto foi aprovado pelo Comitê de Ética da Prefeitura do Município de São Paulo.

De acordo com a resolução CNS/MS 196/96 que regulamenta a ética em pesquisa envolvendo seres humanos no Brasil, foi solicitado a cada uma das mulheres o consentimento para participação na pesquisa. Foi entregue a cada uma das mulheres um Termo de Responsabilidade (Anexo 2), assinado pela pesquisadora e orientadora da pesquisa, que contém os objetivos do estudo; as garantias para a preservação de seu anonimato; omissão de nomes e particularidades que possibilitem a identificação. Neste documento indica-se uma forma de contato com a pesquisadora para esclarecimentos de dúvidas, se necessário. Foram assegurados a liberdade de participação, de recusa e o direito de retirar-se a qualquer momento da pesquisa.

Para preservar o anonimato das mulheres entrevistadas, na descrição dos resultados e discussão seus nomes foram trocados por outros fictícios escolhidos pela pesquisadora. 


\section{RESULTADOS E DISCUSSÃO}

\subsection{CARACTERIZAÇÃO DAS MULHERES ENTREVISTADAS}

Foram entrevistadas seis mulheres com diagnóstico de infecção pelo HIV/AIDS, matriculadas e em acompanhamento no SAE- Butantã, moradoras da área de abrangência e matriculadas no PSF da Supervisão de Área do Butantã, por ocasião da entrevista.

Segue no Quadro 1 abaixo a distribuição das mulheres portadoras do HIV entrevistadas, segundo algumas características sócio-demográficas e o tempo de conhecimento do diagnóstico de soropositividade para o HIV. 
Quadro 1 - Distribuição das mulheres entrevistadas quanto à algumas características sóciedem diagnóstico. São Paulo, Butantã, 2006.

\begin{tabular}{|c|c|c|c|c|c|c|c|c|}
\hline Nome & Idade & Ensino & $\begin{array}{c}\text { Estado } \\
\text { civil/marital }\end{array}$ & $\begin{array}{c}\text { Reside } \\
\text { com }\end{array}$ & Ocupação & $\begin{array}{l}\text { Situação } \\
\text { trabalho }\end{array}$ & $\begin{array}{c}\text { Renda } \\
\text { familiar }\end{array}$ & $\begin{array}{c}\text { Tempo } \\
\text { moradia } \\
\text { bairro } \\
\text { (anos) }\end{array}$ \\
\hline $\begin{array}{c}\text { Safira } \\
001\end{array}$ & 36 & $\begin{array}{c}7^{\circ} \\
\text { Fundamental }\end{array}$ & casada & $\begin{array}{l}\text { marido e } 1 \\
\text { filha }\end{array}$ & $\begin{array}{c}\text { Cuida de } \\
\text { criança e de } \\
\text { casa }\end{array}$ & empregada & $2 \mathrm{SM}$ & 2 \\
\hline $\begin{array}{c}\text { Mayara } \\
002\end{array}$ & 36 & $2^{\circ}$. Médio & $\begin{array}{c}\text { união } \\
\text { consensual }\end{array}$ & $\begin{array}{c}2 \text { filhos } \\
\text { (outros } 2 \\
\text { com avó) }\end{array}$ & recepcionista & desempregada & $<1 \mathrm{SM}$ & 30 \\
\hline $\begin{array}{c}\text { Dalila } \\
003\end{array}$ & 31 & $\begin{array}{c}5^{\circ} . \\
\text { Fundamental }\end{array}$ & casada & $\begin{array}{c}\text { marido, } 1 \\
\text { filha e } 1 \\
\text { enteada }\end{array}$ & segurança & desempregada & $4,6 \mathrm{SM}$ & 2 \\
\hline $\begin{array}{c}\text { Selena } \\
004\end{array}$ & 29 & $\begin{array}{c}6^{\circ} . \\
\text { Fundamental }\end{array}$ & casada & $\begin{array}{l}\text { marido e } 2 \\
\text { filhos }\end{array}$ & aux limpeza & desempregada & $1 \mathrm{SM}$ & 10 \\
\hline $\begin{array}{l}\text { Jade } \\
005\end{array}$ & 45 & $3^{\circ}$. Médio & $\begin{array}{c}\text { separada } \\
\text { (ex marido } \\
\text { falecido com } \\
\text { HIV) }\end{array}$ & 3 filhos & $\begin{array}{c}\text { assistente } \\
\text { administrativo }\end{array}$ & empregada & $5,7 \mathrm{SM}$ & 32 \\
\hline $\begin{array}{c}\text { Aysha } \\
006\end{array}$ & 30 & $\begin{array}{c}4^{\circ} . \\
\text { Fundamental }\end{array}$ & casada & $\begin{array}{l}\text { marido e } 6 \\
\text { filhos }\end{array}$ & bicos & desempregada & $<1 \mathrm{SM}$ & 30 \\
\hline
\end{tabular}

\footnotetext{
${ }^{1}$ Salário Mínimo no valor de R \$350,00, Lei no 11.321, de 07.07.2006, vigência 01/04/2006.
} 
As idades variaram de 29 a 45 anos; a maioria tinha mais de quatro anos de estudo, com exceção de Aysha; somente uma encontrava-se separada e todas residiam com seus filhos, com idades entre um mês e 23 anos. Quatro delas encontravam-se desempregadas; somente Jade possuía ocupação de maior qualificação e é a que tinha maior rendimento familiar (5,7 SM). O tempo de moradia no bairro foi muito variável, sendo o mínimo de dois anos e o máximo de 32 anos. Mais da metade delas freqüentava alguma igreja evangélica e três alguma organização não governamental (ONG). Quatro delas (Safira, Mayara, Dalila e Aysha) sabiam do diagnóstico há menos de dois anos e Selena e Jade, seis e nove anos, respectivamente.

Em relação aos serviços de saúde que realizaram o diagnóstico de infecção pelo HIV e, na seqüência, souberam desta informação e acompanharam o processo saúdedoença, encontram-se sintetizados no Quadro 2. 
Quadro 2 - Distribuição dos locais onde foi realizado o diagnóstico de soropositividade para o HIV, as condições em que ocorreu, os serviços que conhecem o diagnóstico e que acompanham o processo saúde-doença.

\begin{tabular}{|c|c|c|c|c|c|c|}
\hline \multirow[t]{2}{*}{ Nome $^{*}$} & \multirow[t]{2}{*}{$\begin{array}{l}\text { Onde foi } \\
\text { feito o } \\
\text { diagnóstico }\end{array}$} & \multirow[t]{2}{*}{ Condições } & \multirow{2}{*}{$\begin{array}{l}\text { Serviços de } \\
\text { saúde que } \\
\text { conhecem o } \\
\text { diagnóstico }\end{array}$} & \multicolumn{3}{|c|}{$\begin{array}{c}\text { Acompanhamento } \\
\text { do processo saúde } \\
\text { doença }\end{array}$} \\
\hline & & & & SAE & PSF & $\mathrm{HU}$ \\
\hline $\begin{array}{l}\text { Safira } \\
001\end{array}$ & PSF & $\begin{array}{l}\text { Suspeita de HIV do marido } \\
\text { que estava no presídio com } \\
\text { tuberculose }\end{array}$ & $\begin{array}{c}\text { SAE, PSF e } \\
\mathrm{HU}\end{array}$ & Sim & Sim & Sim \\
\hline $\begin{array}{l}\text { Mayara } \\
002\end{array}$ & $\begin{array}{l}\text { Não foi no } \\
\text { SAE, nem } \\
\text { no PSF }\end{array}$ & $\begin{array}{l}\text { História anterior de } \\
\text { alcoolismo e tuberculose }\end{array}$ & $\begin{array}{l}\text { Serviço que fez } \\
\text { o diagnóstico, } \\
\text { PSF e SAE }\end{array}$ & Sim & Sim & Não \\
\hline $\begin{array}{l}\text { Dalila } \\
003\end{array}$ & PSF & Exames do pré-natal & PSF e SAE & Sim & Não & Não \\
\hline $\begin{array}{l}\text { Selena } \\
004\end{array}$ & $\begin{array}{l}\text { Posto }^{2} \\
\text { Não foi no } \\
\text { PSF }\end{array}$ & $\begin{array}{c}\text { Diagnóstico do marido } \\
\text { durante internação por } \\
\text { convulsão } \\
\end{array}$ & HU e SAE & Sim & Não & Não \\
\hline $\begin{array}{l}\text { Jade } \\
005\end{array}$ & SAE & $\begin{array}{l}\text { Diagnóstico do ex-marido } \\
\text { durante internação por } \\
\text { traumatismo craniano }\end{array}$ & SAE & Sim & Não & Não \\
\hline $\begin{array}{c}\text { Aysha } \\
006\end{array}$ & PSF & Exames do pré-natal & PSF e SAE & Sim & Sim & Não \\
\hline
\end{tabular}

Metade delas, Safira, Dalila e Aysha, teve o diagnóstico de soropositividade ao HIV realizado em uma das unidades de PSF da Supervisão da Área do Butantã. O diagnóstico de infecção pelo HIV de Dalila e Aysha foi realizado durante o acompanhamento do pré-natal, através dos exames laboratoriais de rotina.

Safira, Selena e Jade tiveram seus diagnósticos realizados após suspeita da infecção de seus parceiros sexuais. Jade comentou que demorou pelo menos quatro anos para fazer o exame de detecção do vírus. Safira teve o seu diagnóstico de soropositividade conhecido após suspeita de HIV do marido presidiário que estava com tuberculose, doença indicativa de possível associação com a infecção pelo HIV e Jade soube na ocasião da internação do marido.

\footnotetext{
2 * a usuária referiu "posto de saúde", e diz que o diagnóstico não foi no PSF e não foi no
} SAE. 
Entre todas, somente com Mayara o diagnóstico foi feito a partir de história pregressa de alcoolismo e tuberculose. Após o diagnóstico, ela veio a engravidar.

Portanto, três delas foram diagnosticadas após suspeita ou diagnóstico de soropositividade pelo HIV de seus parceiros e duas no período de gestação.

Parece acontecer com freqüência, mulheres que só realizam testagem sorológica após suspeita da infecção pelo HIV do parceiro ou ex-parceiro sexual. Como apontado por Vermelho et al (1999) em seu estudo, algumas mulheres só se submeteram a testagem sorológica para HIV após doença ou morte do companheiro.

Após o diagnóstico de infecção pelo HIV, Safira, Dalila e Aysha, grávidas, foram acompanhadas no SAE Butantã, realizando o controle do pré-natal e tratamento com anti-retrovirais durante a gestação e após o parto, assim como as crianças. Os filhos nascidos destas mulheres tiveram os seus exames laboratoriaisde detecção do vírus negativos, ou seja, não foram infectados.

Mayara e Selena não foram diagnosticadas com infecção pelo HIV nas unidades do PSF, mas em outra unidade não identificada. Jade teve seu diagnóstico realizado no SAE Butantã. Todas encontravam-se em acompanhamento no SAE Butantã. Segundo supõe-se, a equipe do PSF não conhece o diagnóstico de soropositividade de Selena e Jade. Somente Mayara revelou sua condição de soropositividade para a equipe do PSF, segundo ela, por possuir um vínculo anterior com os profissionais de saúde da equipe.

Dalila, embora cadastrada no PSF, não realiza acompanhamento do processo saúde-doença/aids no PSF, apesar da equipe conhecer o seu diagnóstico. Refere que apesar de estar cadastrada no serviço não freqüenta a unidade do PSF nem mesmo para assuntos não relacionados ao HIV. Vale ressaltar que esta mulher teve uma 
experiência negativa no momento do recebimento do diagnóstico de soropositividade, que foi realizado por meio dos exames do pré-natal, no PSF. Mas mesmo não sendo acompanhada por este serviço, após o parto, quando recebeu a visita de um ACS em sua casa, abriu a privacidade das informações contando ser portadora do HIV ao ACS.

Selena e Jade, também cadastradas pela equipe de PSF, não são acompanhadas no que tange às questões que envolvem a infecção pelo HIV, porque as equipes desconhecem a soropositividade ao HIV dessas mulheres, e as mesmas não demonstram interesse em abrir a privacidade desta informação. Selena não freqüenta o PSF para nenhum processo relacionado à sua saúde, relata que somente utiliza os serviços do PSF para o cuidado dos seus filhos.

Jade, apesar de ser cadastrada no PSF, não realiza nenhum tipo de acompanhamento à saúde no PSF, porque, por trabalhar durante a semana em horário comercial, não está em casa no período que são realizadas as visitas pelos ACS.

A partir da transcrição das entrevistas e da decomposição dos depoimentos foram extraídas as categorias "compartilhando o segredo com familiares, amigos e vizinhos" e "compartilhando o segredo com a equipe do PSF", que sintetizam as condições e os motivos que levam (ou não) as mulheres portadoras do HIV a revelarem o diagnóstico a estes sujeitos.

Prossegue a descrição dos resultados encontrados nos discursos. 


\subsection{COMPARTILHANDO O SEGREDO DO DIAGNÓSTICO DE HIV COM FAMILIARES, AMIGOS E VIZINHOS}

Considera-se que cada mulher portadora do HIV tem uma história singular e que cada uma delas possui particularidades, mas no processo saúdedoença existem semelhanças que podem ser estendidas a autras mulheres infectadas pelo HIV/AIDS. Não se pretende no presente estudo fazer generalizações, no entanto, espera-se contribuir para que, no conjunto dos discursos seja possível compreender em que condições se dá a abertura da privacidade em relação à informação sobre a soropositividade à equipe de PSF, para subsidiar a melhoria da qualidade de assistência.

Verifica-se que algumas mulheres contam a outras pessoas sobre sua condição de soropositividade assim que ficam sabendo o diagnóstico, outras preferem guardar para si. De qualquer maneira, a escolha, a decisão de compartilhar o conhecimento sobre sua condição gera conflitos internos, aflorando sentimentos de medo e ansiedade. Inicialmente será abordado este processo de dúvida entre contar (ou não) a outros, para depois elucidar as condições nas quais as mulheres acabam abrindo sua privacidade em relação à informação sobre seu diagnóstico.

A condição de soropositividade traz muita instabilidade à vida das pessoas, tanto para quem é portador quanto para os familiares e amigos. As mudanças são numerosas e intensas (Lopes e Fraga, 1998). Diante disso, verificase que abrir a privacidade, ou seja, contar (ou não contar) sobre segredo de sua soropositividade é cercado por dúvidas. As dúvidas dizem respeito especialmente às possíveis reações das pessoas e refletem o comportamento da sociedade diante da epidemia de aids em relação aos seus portadores. Compartilhar o segredo do diagnóstico de 
soropositividade afeta os processos de comunicação e relacionamento com estas pessoas (Stefanelli et al, 1999).

Uma questão diz respeito ao medo do preconceito e da discriminação, importantes nesse processo de tomada de decisão sobre compartilhar o segredo. Ao longo dos anos a população vem desenvolvendo pensamentos e atitudes estigmatizantes e discriminatórios em torno das doenças sexualmente transmissíveis e a tudo aquilo que possa se relacionar com elas (Lopes e Fraga, 1998). Infelizmente, a discriminação e o estigma ou preconceito estão presentes na vida dos portadores do HIV, fruto da história da doença.

A vivência de experiências de discriminação e preconceito ao longo da vida pode influenciar a abertura (ou não) da privacidade. $\mathrm{O}$ conflito que envolve a pessoa portadora do HIV, ao decidir contar (ou não) e a quem contar, diz respeito especialmente ao sentimento de confiança de que será apoiada, ouvida e receberá acolhida. As mulheres se preocupam com a quebra da confiança depositada nas pessoas com quem compartilharam o segredo.

As experiências positivas, ou seja, quando ao contar houve apoio, levam as mulheres a confiar mais nas outras pessoas, o que influencia na abertura da privacidade a outros de seu convívio familiar e aos profissionais. Já as experiências negativas levam as mulheres a desconfiar mais e a necessita de provas para que possam voltar a confiar nas pessoas, isso ocorre, por exemplo, quando ao contar para a família, experimentam o sentimento de rejeição.

O medo de que haja preconceito se estende a outros, desta forma em alguns casos as mulheres mantêm oculta a informação sobre sua contaminação para proteger os familiares e filhos da rejeição e discriminação que possam sofrer. Muitas mulheres 
omitem a doença da família, dos amigos e até dos próprios parceiros (Flaskerud, 1992; Vignare, 1999).

Várias condições envolvem o processo de amadurecimento da decisão de contar (ou não). Algumas pessoas infectadas pelo HIV, após passar por uma fase de querer manter para si a informação sobre o diagnóstico, procuram inicialmente algum amigo, membros da família e grups de ajuda terapêutica ou de convivência (Stefanelli et al, 1999).

Após o processo de dúvida sobre contar (ou não) o segredo do diagnóstico de soropositividade ao HIV às pessoas, há a tomada de decisão. A seguir, no Quadro 3, agruparam-se as condições, extraídas dos discursos das entrevistadas, que levam as mulheres a abrir sua privacidade em relação à informação sobre o seu diagnóstico de soropositividade ao HIV/AIDS.

Quadro 3: Condições que levam as mulheres a contar (não contar) o segredo sobre o diagnóstico de infecção para o HIV aos familiares, amigos e vizinhos.

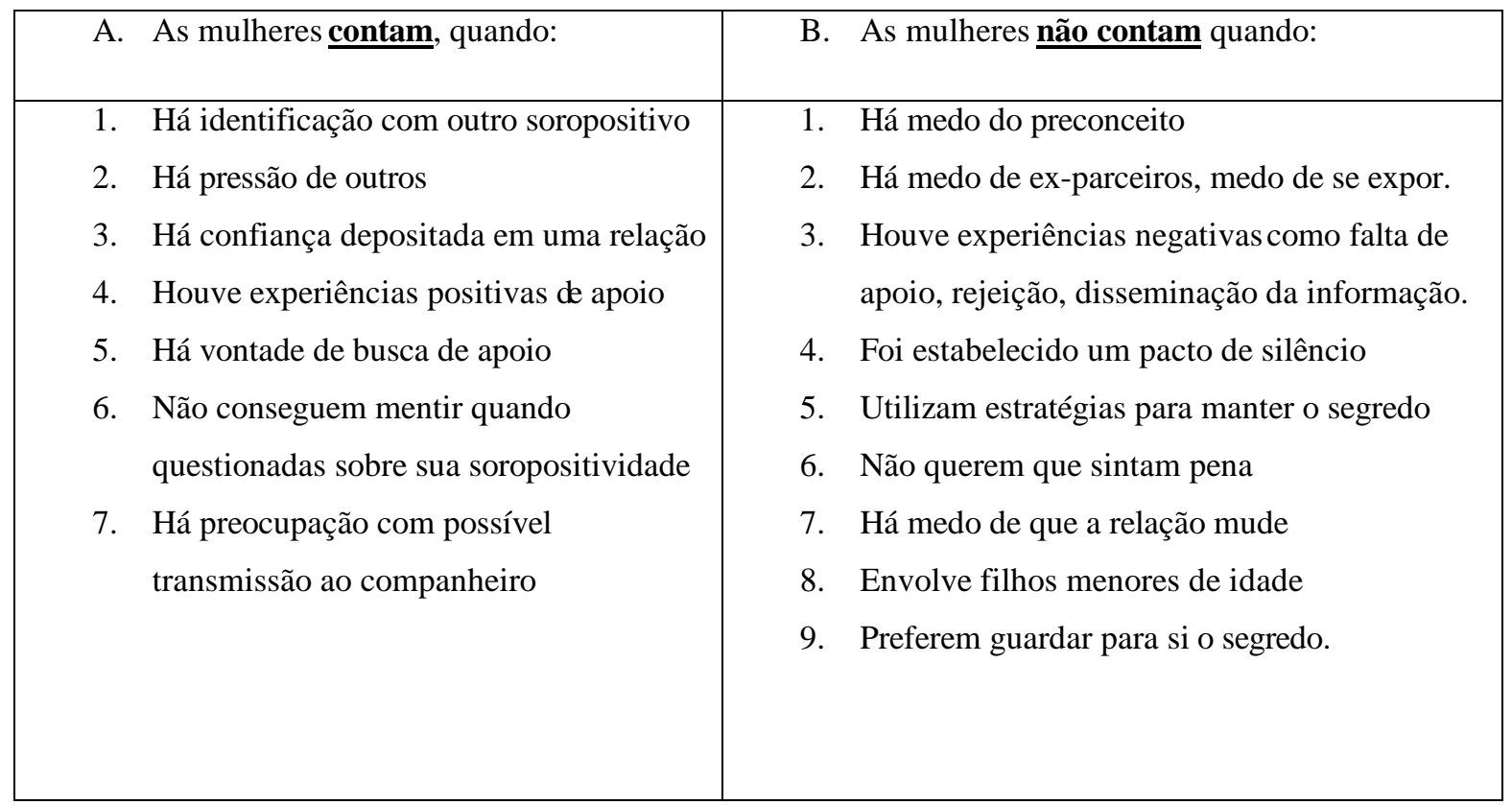




\section{A. CONTAM}

\section{A.1. Há identificação com outro soropositivo}

Uma condição que auxilia a abertura da privacidade das informações a outras pessoas é compartilhar seus temores, medos e angústias com outras pessoas que se encontram infectados pelo HIV.

Quando o soropositivo ao HIV/AIDS sente necessidade de desabafar, de se expressar ou até mesmo de tentar diminuir a pressão que sente por não dividir seu diagnóstico com alguém, por muitas vezes, procura a ajuda de outros soropositivos (Stefanelli et al, 1999). É no apoio de semelhante que muitas vezes o ser humano consegue se expressar e buscar forças para superar um momento difícil da vida ou uma angústia.

Na fala abaixo exemplificamos tal atitude:

"[...] Então esse dia que eu falei para a mãe do meu amigo, aí ela se abriu comigo, falou - olha, eu não quero que você fale para a minha nora nem para meu filho, mas eu também tenho [aids] -, aí eu falei para ela-por que você não fala para eles, quem sabe se você não vai se sentir melhor, eles vão te ajudar, porque assim ... você tem seu trabalho, mas você se isola de tudo. Chega o final de semana você se tranca no seu quarto, você não quer saber de ninguém, ninguém pode conversar com você, você vive mal humorada por isso -, e fui conversando com ela, né? Aí ela pegou e falou para a nora dela, primeiro falou com a nora dela. Depois a nora dela conversou com o filho dela." Dalila 
Na fala acima, quando a entrevistada revelou sua condição a uma pessoa que a família desconfiava ser soropositiva ao HIV/AIDS, ela acabou compartilhando o seu segredo, considerou a opinião de outra pessoa também portadora do HIV. Tal atitude ajudou a revelar sua condição à família.

Tal forma de apoio, por vezes, é também encontrada em grupos de ajuda e grupos terapêuticos, muitas vezes oferecidos pelas próprias instituições que freqüentam.

"Eu participo assim do grupo de manhã de adesão, $5^{a}$ feira, né? Então me ajuda bastante, o grupo de manhã, me ajuda bastante. E aí eu tiro minhas dúvidas. Aí a gente vai vendo que não é uma coisa assim... bicho de sete cabeças, é uma doença, só que não tem cura e tem como não fazer com que ela mata a gente, né?" Safira

O grupo possibilita ao participante uma fonte de apoio e encorajamento, faz diminuir seus medos, ansiedades, o sentimento de isolmento e facilita o aprendizado de novas formas de enfrentar o viver com o HIV/AIDS (Rasera e Japur, 2003).

\section{A.2. Há pressão de outros}

Há situações em que as mulheres não queriam abrir, compartilhar o segredo sobre seu diagnóstico, mas foram de alguma forma pressionadas. Expressa na fala abaixo, identificourse uma situação em que a mulher foi levada a revelar sua condição de portadora a um membro da família:

“Ah ... eu cheguei nela, chamei ela ... eu não queria falar, né? Aí a minha sogra pediu para eu falar, chamou ela lá em casa e eu falei. 
Falei que estava com o vírus HIV, que meu marido estava e que eu tinha pegado também. Aí ela ... sei lá, acho que ela não ficou triste na hora, para não me deixar mais triste, né? Minha mãe supera mais do que eu." Selena

\section{A.3. Há confiança depositada em uma relação}

Os indivíduos soropositivos ao HIV/AIDS demonstram, muitas vezes, em suas falas, sentimentos relacionados à família e amigos e como gostariam que eles reagissem ao saber que eles estão infectados ou estão com aids (Stefanelli et al, 1999). E isto pode influenciar a busca por compartilhar o segredo do diagnóstico com outras pessoas.

Uma pessoa revela o seu segredo a alguém por uma esperada qualidade humana e que envolve o sentimento de amizade, confiança (Llano, 1991). E ao dividir a informação sobre o diagnóstico, a confiança depositada, no sentido de que guarda o segredo é posta em prova:

"eu contei assim, porque achei que ela deveria saber, assim, pela amizade que a gente tinha. E aí eu ia passar a conhecer quem realmente seriam meus amigos. Se ela fosse minha amiga de verdade, ela não iria se afastar de mim. Mas se ela não fosse ela iria se afastar." Dalila

\section{A.4. Houve experiências positivas de apoio}


Quando houve experiências positivas de apoio ao revelar a alguém o segredo, ou seja, quando efetivamente estiveram presentes sentimentos de aceitação e amizade, observa-se que tal experiência teve caráter positivo e foram determinantes para que a mulher passasse a dividir o segredo sobre sua condição de soropositividade com outros. Quando a mulher soropositiva revela a alguém sua condição, na maioria das vezes ela está em busca de apoio, se esta característica é suprida em momentos posteriores, essa mulher vai se sentir mais segura ao revelar o segredo a outros.

O apoio familiar e de amigos é muito importante, segundo Stefanelli et al (1999) perceberam, algumas famílias de pessoas infectadas pelo HIV/AIDS expressaram, através da fala, frases de aceitação, apoio e conforto. Isto é possível verificar no discuiso abaixo:

“Contei, eu contei pra duas amigas, contei pra minha cunhada é... pra irmã do meu marido, contei pra minha família, a minha mãe e os meus irmãos né? Assim eles falam assim pra mim: Ah, mas tem tanta gente que tem essa doença, essa doença não mata. Mas só de saber assim que tá com um bicho, assim no corpo, sabe, dá uma agonia. Hoje assim eu não agüento ver sangue, quando só de... eu vou escovar os dentes e sai sangue. Nossa! Já fico até com medo, eu acho que tá cheio de bicho, é aquela coisa que... Então, eu contei pra eles todos, eles me deram a maior força, falaram e sempre falam a mesma coisa. (...) falam pra eu, que é pra eu me cuidar. Não tem, comigo eles não têm aquele preconceito que eu sei que eles teriam, né? A família está mais, 
tá mais assim ligada comigo. Me liga todos os dias, me ajuda do jeito que pode." Safira

\section{A.5. Há vontade de busca de apoio}

Para abrir a privacidade é importante a vontade expressa de busca de apoio.

A necessidade de buscar apoio, como já dito anteriormente, torna-se imperiosa quando guardar pra si não traz conforto, e a vontade de poder conversar sobre algo que faz parte de sua vida se faz presente. A vontade expressa de buscar apoio, por muitas vezes, foi encontrada nos discursos e, independentemente, se a procura foi por amigos ou familiares.

Segundo Stefanelli (1993), os portadores do HIV em geral procuram primeiro os amigos, depois os grupos de apoio, para depois buscarem apoio da família, de quem esperam compreensão e afeto. Já Vermelho et al (1999) em seu estudo apontaram ser a família, ou alguns membros desta, os primeiros a receber a informação do diagnóstico de soropositividade ao HIV das mulheres entrevistadas.

"Ah, eu pensei assim que poderia me ajudar de alguma forma. Então eu, tipo, no primeiro momento, é o que a gente quer ouvir, né, é uma assim, palavra assim de amigo, no primeiro momento foi isso. E realmente, eu consegui." - Safira

No presente estudo verificou-se que de as entrevistadas expressaram vontade de compartilhar com outras pessoas, particularmente outras mulheres (mães, filhas, amigas), diferentemente dos homens, que não viam necessidade. 


\section{A.6. Não consegue mentir quando questionada sobre sua soropositividade}

Algumas das mulheres entrevistadas revelaram que quando questionadas sobre sua condição de soropositividade acabam contando, porque não conseguem mentir. $\mathrm{Na}$ impossibilidade de mentir sobre sua condição de soropositividade, acabam contando a contragosto. Situação difícil para estas mulheres que decidiram não contar, mas, por não conseguirem mentir ou esconder acabam revelando seu segredo. Como exemplificado no trecho abaixo:

“Aí ela perguntou para mim. Aí quando me perguntam, eu sou obrigada a falar, eu não consigo mentir. Aí ela perguntou e eu falei para ela, uma colega minha. Mas eu não fico falando para as pessoas, só se a pessoa me prensa assim na parede e pergunta para mim." Selena

\section{A.7. Há preocupação com possível transmissão do vírus ao parceiro}

Uma condição que leva as mulheres soropositivas a compartilhar o segredo do diagnóstico encontra-se na preocupação com possível transmissão do vírus ao parceiro, particularmente quando não se sabe se o parceiro é portador ou não.

Há medo do julgamento sobre seu caráter e de sentir-se rejeitada. Há medo de que o parceiro possa ter sido contaminado e isto faz com que a mulher compartilhe o segredo sobre seu diagnóstico. No presente estudo, duas mulheres tinham parceiros sexuais que não estavam infectados pelo vírus, chamados de sorodiscordantes.

Após a revelação do diagnóstico, a preocupação com a possível transmissão do vírus torna-se mais imperativa, especialmente, quando o casal sorodiscordante, se relaciona sem o uso de condom (preservativo). Isto ocorreu com uma das 
entrevistadas que não mantinha relações sexuais com proteção de barreira por vontade do marido e contra a vontade dela.

"Ele é negativo. Apesar que faz tempo que ele não faz exame. Ele colheu no ano passado e ele não quer usar preservativo, ele não ... ele fala - 'Não, se tiver que acontecer eu quero que aconteça comigo também' -, tanto é que quando ... isso ... o dia que eu recebi o resultado eu vim aqui e fiz outro exame. Antes de eu receber o resultado ele falou para mim - 'Nega, se der positivo, eu te amo tanto que eu vou cortar ... assim ... fazer um corte em mim e em você, e a gente vai pôr um sangue no outro, eu quero ter a mesma coisa que você'-. E até hoje a gente nunca usou preservativo. Ele não quer.

Eu cobro muito do meu esposo, eu falo - vai lá, faz um exame -, e ele'Ah, deixa, depois eu vou, eu estou bem, né?' -. E eu fico muito curiosa, será que iria me sentir muito culpada, que ele tivesse pegado também o vírus, mas é por uma opção dele, ele não quer usar preservativo, de forma alguma. Então, o que eu cobro muito dele, para ele vir logo, porque se está no começo tem como você tratar melhor, e ele não quer vir. Ele fala - não...-, como ele trabalha muito, ele fala'Não, o dia que eu tiver um tempo eu vou' -, e ele vai me enrolando, ele nunca vem (...) eu me sinto mal, porque eu quero cuidar dele também, não só de mim, não adianta pensar só em mim, tenho que pensar nele também. A gente tem relação sem preservativo, eu tenho que me preocupar com ele também, né." - Dalila 
A motivação que leva uma mulher a contar sobre o seu diagnóstico também se estende a parceiros anteriores, inclusive com aqueles que possam ter transmitido o vírus, conforme se observa na fala abaixo:

“Depois desse amigo eu contei pro namorado, que era a pessoa que tinha me passado [o HIV], e... só que eu já não estava mais com ele, eu já tinha largado ele e estava namorando outra pessoa. Aí eu tive que contar para essa outra pessoa, né? Essa outra pessoa foi muito legal comigo, ficou comigo. Quis ficar sério mesmo comigo, aí foi morar logo junto comigo.” - Mayara

\section{B. NÃO CONTAM}

\section{B.1. Há o medo do preconceito}

Um dos motivos que levam as mulheres a não compartilhar a informação sobre sua soropositividade, como já foi dito, é o medo do preconceito e da discriminação. $\mathrm{Na}$ sociedade, a soropositividade e a aids diferenciam os portadores das outras pessoas, com estigmas como "aidético". Tal forma de se referir ao portador do HIV vem de uma tentativa de desmerecer essas pessoas (Tunala, 2002). Essa forma de enfrentamento da doença reforça a segregação das pessoas pertencentes à sociedade, que são vistas, distorcidamente, como ameaça ao "bem-estar social".

O preconceito e a discriminação existentes configuram grandes desafios que a mulher infectada pelo HIV/AIDS tem que enfrentar. A sociedade acompanhou a história da aids desde a descoberta até os dias atuais. Os equívocos ocorridos no 
início da epidemia reforçaram o preconceito e a discriminação com os portadores do HIV.

Como relatam Bagnara e Cardoso (2005), a informação incorreta e distorcida sobre a aids veiculada pelos meios de comunicação fez com que o HIV se convertesse num mal que ameaça a população, sendo inclusive um fator a mais de violência contra as mulheres.

Pois quando apontava para grupos e comportamentos de risco, tirava do âmbito familiar e relações supostamente monogâmicas a possibiildade de contrair o vírus HIV, dificultando a capacidade da mulher de se proteger pedindo o uso do condom ao parceiro. Além do fato de que, como apontado por Porto et al (2003), devido às relações de gênero, algumas mulheres acreditam que manter relações sexuais com o companheiro constitui uma obrigação conjugal, e que pedir o uso do condom configuraria admitir a infidelidade no relacionamento.

As doenças sexualmente transmissíveis por si só são envoltas de estigma e preconceitos, a aids acentua estes aspectos e é associada principalmente a comportamentos discriminados pela sociedade. Uma das entrevistadas fez o seguinte relato:

“A grande maioria não te aceita como um cidadão normal. Existe muito preconceito, você é rotulada, é discriminada em qualquer parte.

Infelizmente." - Jade

A discriminação deriva da distinção feita com base no pertencimento ou na percepção que alguém é pertencente a um grupo particular, resultando em tratamento iníquo e injusto (Richter, 2001). Segundo Richter (2001), “alguém que 'inofencivamente', ou talvez secretamente, abriga preconceito contra um indivíduo 
ou grupo traduziria em discriminação apenas quando agisse com base neste preconceito", ou seja, discriminação contra alguém é tratála de modo desigual ou diferente de outras pessoas.

Na perspectiva da mulher estigmatizada, a diferença se dá entre sentirse ou ser efetivamente estigmatizada, por ação ou omissão. Do ponto de vista do estigmatizador, a diferença se dá entre abrigar e alimentar preconceitos ou agir ou omitir-se com base nestes.

\section{B.2. Há medo de ex-parceiros, medo de se expor.}

O preconceito e a discriminação também geram outros conflitos, principalmente, quando há a possibilidade de a mulher ter se infectado por ex companheiros, e o atual parceiro ser soronegativo. Isto faz com que algumas mulheres não contem para seus ex-parceiros.

Contar para o ex-parceiro torna-se uma tarefa difícil, porque a mulher tem que expor sua intimidade a uma pessoa com a qual teve um relacionamento e que não possui mais nenhum vínculo aetivo. Sendo mulher, ela tem medo de ser julgada como promíscua, acrescenta-se a presença de uma relação atual afetiva e sexual, onde o parceiro atual não quer que haja a procura pelo ex-companheiro.

“(...) segundo ela, ela pegou do namorado dela, que ele usava drogas injetáveis, né? Eu já no meu caso não sei, não sei de quem. No meu primeiro... eu fiquei casada 10 anos no meu primeiro casamento. Aí depois de três anos ... aí depois eu separei, e depois de três anos que eu vim conhecer meu atual marido, né? E ele é negativo, então, aqui o pessoal fala - ah, por que você não procura o seu ex-marido, vê se ele tem, para poder ele se tratar, vai que ele não descobriu ainda. Só que meu marido não deixa, ele fala: - 'Não, não quero que você se 
exponha a esse tipo de coisa.' - Então eu não sei de quem eu peguei.

Não sei mesmo. " - Dalila

\section{B.3. Houve experiências negativas como falta de apoio, rejeição, disseminação da informação.}

As experiências negativas vivenciadas pelas mulheres quando contaram sobre sua positividade ao HIV fazem com que passem a não compartilhar a informação sobre o diagnóstico. As experiências foram negativas porque houve falta de apoio, rejeição e de alguma forma houve disseminação da informação a outras pessoas, não autorizada pelas mulheres.

Estiveram envolvidos nestas situações desde amigos, membros da igreja e familiares. Houve desde atitudes de não oferta de escuta e auxílio e apoio, até atitudes extremas, como a exclusão do membro da família.

Segue abaixo uma fala onde se expressa a falta de apoio esperado:

"Minha mãe que contou, ficaram [os familiares] todo mundo apavorado, mas ninguém foi lá em casa. Nunca foram, faz 10 anos que eu moro com meu marido, ninguém foi lá em casa. Então acho que não devia ter contado, porque eles não ajudam, só vai ter pena mesmo. A única pessoa que liga para mim para perguntar se eu estou bem é minha mãe e a minha tia, a outra tia, a solteira. Porque as outras também não perguntam ..." - Selena

A família nem sempre oferece apoio às mulheres infectadaspelo HIV/AIDS por medo do julgamento da sociedade. Muitas vezes não suportam a idéia de ter uma pessoa infectada pelo HIV/AIDS como membro da família(Barroso et al, 1998).

Segundo a fala de uma das mulheres, houve não só a falta de apoio como houve rejeição: 
"Mas eu ficava pensando - eu vou contar para a minha mãe, o que ela vai fazer? Será que ela vai me dar apóio, será que ela vai me dar as costas? -, então já me preparei para aquilo, porque dependendo da situação dela, do que ela ia fazer, eu já estava preparada. E aí, o que ela fez? Ela me deu as costas. Ela, minhas irmãs... Então só tenho apoio do meu filho e do meu marido." - Aysha

Barroso et al (1998) afirmam que o apoio de amigos e parentes, desejado pelas mulheres, nem sempre acontece. Isto ocorre porque em algumas situações a família, imersa em preconceitos, não se sensibiliza com o estado da mulher infectada pelo HIV/AIDS. Em alguns casos, verificaram que os pais chegaram a expulsar a filha de casa e com isso acreditam que resolveram o problema.

Uma outra experiência negativa foi relatada por duas das mulheres. Quando elas buscaram apoio, compreensão e, principalmente, sigilo sobre o conhecimento sobre seus diagnósticos, houve disseminação da informação a outras pessoas não autorizadas.

"Freqüento [igreja], mas lá também eu não falei para ninguém. Porque uma vez eu falei com o pastor de uma igreja e todo mundo da igreja ficou sabendo. Então, eu achava que todo mundo estava olhando diferente para mim. Então, prefiro não contar para ninguém da igreja também. Eu vou, como uma pessoa normal, mas não falo dos meus problemas também, não. Faço minhas orações lá e vou embora.” Selena

\section{B.4. Foi estabelecido um pacto de silêncio}

Um dos motivos que levam as mulheres a não compartilhar o segredo do seu diagnóstico é o estabelecimento de um pacto de silêncio, que consiste num acordo de 
não revelar o diagnóstico de soropositividade a ninguém, no caso, o segredo é compartilhado entre aqueles que estabeleceram o pacto. Houve esta situação em relação ao casal, decisão esta tomada pelo homem que buscou estabelecer o pacto, contrariando o que ela desejava para si mesma, ou seja, conversar sobre seu diagnóstico com outras pessoas. No discurso de duas entrevistadas apareceu essa condição de pactuar o segredo a pedido dos companheiros.

“E ele queria fazer um pacto comigo que ninguém mais podia saber disso. Só nós dois.” - Dalila

Nos dois casos, as mulheres asseguraram o cumprimento do pacto e mantêm durante um período de tempo, no entanto, a despeito da vontade dos parceiros, acabaram revelando o segredo a pessoas de sua confiança. Diferentemente dos homens que acabam, de um modo geral, guardando o segredo.

O fato de os parceiros não quererem compartilhar o segredo do diagnóstico com outras pessoas leva a refletir que esta é uma condição de gênero, no sentido de que o homem, ao compartilhar com outras pessoas a informação sobre a soropositividade, seja do casal, quanto da companheira, expõe uma situação que pode ser interpretada por eles como fraqueza, como algo que foge ao seu controle. Ao contrário, as mulheres têm como característica a necessidade de compartilhar dúvidas, angústias, alegrias com outras pessoas, particularmente outras mulheres. Nota-se que o homem impõe à mulher sua vontade, no sentido do estabelecimento de um pacto, como uma necessidade dele e não da companheira.

\section{B.5. Utilizam estratégias para manter o segredo}

As mulheres utilizam várias estratégias para manter a privacidade das informações. 
A manutenção de um segredo não configura uma tarefa simples, já que muitas vezes, por situações cotidianas ou desconfiança, as pessoas questionam certos comportamentos e condutas, e a mulher se sentindo pressionada, mas não querendo abrir o segredo, se vê levada a mentir ou esconder, e para isso lança mão de diversas estratégias. Situação desconfortável para essas mulheres e que, possivelmente, gera influências negativas nas suas vidas.

Barroso et al (1998) apontam que a curiosidade dos indivíduos e a reação de algumas famílias de portadores exemplificamalgumas destas influências negativas. Como por exemplo, exteriorização de preconceitos e discriminação, disseminação da informação e o isolamento social.

No exemplo abaixo, quando uma das mulheres esteve na maternidade, dividindo o quarto com outras mulheres, havia a preocupação em manter a privacidade da informação, não querendo que outras mulheres e até trabalhadores da equipe de enfermagem soubessem de sua condição de soropositividade ao HIV:

"Tanto é que quando a minha filha nasceu foi muito difícil para a gente, nós dois, lá dentro do hospital estar escondendo isso, né? Porque vinham as enfermeiras, traziam o remédio para ela, - ah, o que é isso? , -não, um xaropinho, porque ela está com tosse, ela ingeriu líquido, então a gente conseguia ... - ah, por que você não amamentou?, - porque eu não amamentei, né, -- ah, porque ela teve diabete gestacional, ela tomou muito medicamento então o médico achou melhor não amamentar. Então, teve todas essas perguntas. E para mim eu sofri muito ali, num quarto com outras mães ali amamentando, e você não poder amamentar.” - Dalila

\section{B.6. Não querem que sintam pena}


Uma situação importante revelada nos discursos e que influencia a não abertura da privacidade é que as mulheres não querem que as pessoas sintam pena delas,e esse sentir pena é caracterizado por sentir-se colocada numa posição de fragilidade e as pessoas que as colocam nessa situação não oferecem ajuda ou apoio. Acreditarse que o sentimento de não querer que sintam pena está ligado ao fato de que a pena as coloca em uma posição de inferioridade em relação às outras pessoas.

“É uma coisa que ninguém pode ficar sabendo. Porque, igual meu marido fala já vai ficar com pena da gente, vai achar que a gente vai... fica aquele medo."-- Safira

“Por mim ninguém sabia, nem a minha família, mas a minha mãe também falou com a minha família [...]. Então eu falo para a minha mãe - que adiantou você ter falado? A pessoa só vai ter pena de mim. Então era melhor não ter falado." - Selena

\section{B.7 Há medo de que a relação mude}

O medo da mudança na relação configura fator importante na decisão de não compartilhar o segredo do diagnóstico de soropositividade ao HIV/AIDS a alguém. Muitas vezes, esta atitude foi tomada por experiências anteriores nas quais houve mudança na relação. E, em outras vezes, porque o receio de que a qualidade da relação mude é imperativo, neste processo de tomada de decisão. O sentimento de medo do preconceito e da discriminação permeia essa questão.

O relacionamento com amigos é muito valorizado pelos soropositivos, que em alguns momentos escondem o próprio diagnóstico para que não haja mudança na relação, principalmente, afastamento. E, em outros momentos tomam a iniciativa de 
auto-isolar-se, pela mesma razão, e muitas vezes, os amigos parecem não compreender tal atitude (Lopes e Fraga, 1998).

"Eu tenho vontade de contar para minha cunhada, que ela é uma pessoa muito esclarecida nisso. Só que eu tenho medo da reação dela, que é a irmã dele, eu tenho medo pelo preconceito, são pessoas muito preconceituosas, então eu tenho medo da reação dela, tenho muito medo, dela se afastar de mim, da minha filha, que as duas são muito apegadas, então eu prefiro ficar na minha. Eu sinto vontade de falar, mas ao mesmo tempo eu prefiro não falar.” -- Dalila

\section{B.8.Envolve filhos menores de idade}

Por vezes a motivação por não contar o diagnóstico é tomada pelos pais ou responsáveis por filhos menores, por considerarem que sejam jovens demais para entender as implicações do HIV e a questão da manutenção do segredo.

"Ele sabe que o pai dele tem problema. Mas assim, eu não cheguei e falei que era HIV, que eu não sei se ele vai entender. $O$ menino tem 7 anos, a menina tem 9. Então, eu não sei ... acho que não está na hora ainda para falar. Eles sabem que a gente faz um tratamento, que faz exames, toma remédio. Isso ele sabe, eu falo - vamos no médico -, que a gente fala com o pessoal que não vai entender nada. A criança não tem muita noção do que é. Eu prefiro não falar, por enquanto não. Eu vou chegar e vou esclarecer, mas por enquanto, eles são muito crianças ainda para entender." - Selena

\section{B.9. Preferem guardar para si.}

Uma das mulheres entrevistadas referiu que preferia guardar o diagnóstico para si, ou seja, manter sua fechada privacidade. E assim manteve por quase dez anos depois da confirmação do diagnóstico de soropositividade, revelando seu segredo a apenas uma das três filhas. Todas as filhas desta mulher eram maiores de 18 anos. $\mathrm{O}$ 
processo de enfrentamento da soropositividade por esta mulher é difícil, uma vez que só buscou fazer o diagnóstico após quatro anos de conhecido o do seu ex-marido, quando esteve internado. E, demorou nove anos para revelar, pela primeira vez que estava infectada pelo HIV à filha mais velha.

Vermelho et al (1999) verificaram em seu estudo que uma de suas entrevistadas disse não ter contado a ninguém o segredo do diagnóstico, até o momento em que não pôde mais esconder. Concluíram que tal atitude trouxe prejuízos em termos de terapêutica e de preservação de sua vida.

Os prejuízos advieram da falta de apoio familiar, a dificuldade de realizar o tratamento escondido de suas filhas, que residiam na mesma casa, e a angústia por manter em segredo o diagnóstico.

Nos resultados do estudo de Barroso et al (1998), uma característica marcante foi o fato de que uma das mulheres participantes esperou "tomar coragem" para poder realizar o exame. No estudo de Lopes e Fraga (1998), quase metade dos entrevistados relatou auto-isolamento ou escolheu não revelar sua condição de soropositividade.

Esta atitude fica clara na fala de uma das mulheres:

"Guardo e vou continuar guardando. Para a minha família, colegas de trabalho, amigos, todos." - Jade

Ao descrever as condições nas quais as mulheres infectadas pelo HIV abrem a sua privacidade em relação à informação sobre o điagnóstico de soropositividade a familiares, amigos e vizinhos, revelouse que quando a mulher soropositiva ao HIV/AIDS enfrenta o desafio de viver com aids, ela também continua enfrentando as 
relações de poder na sociedade, principalmente as desigualdades de gênero, que permeiam de forma tão contundente o papel do ser mulher na sociedade.

Por essa característica tão peculiar foram levantadas várias condições que levam a mulher infectada pelo HIV a abrir a privacidade de suas informações em relação ao seu diagnóstico de soropositividade. Destaca-se neste estudo que a necessidade de revelar algo que lhe é íntimo e que lhe traz receios faz com que a mulher busque, principalmente, a família nuclear e os amigos para dividir seu segredo, e que a relação de confiança é fundamental para que isso ocorra. É claro, que algumas vezes esse laço de confiança pode ser quebrado e que as expectativas destas mulheres não sejam supridas quando revelam o diagnóstico. Mas, na busca de apoio há a esperança de encontrar aquilo que procuram: carinho, compreensão, auxílio e solidariedade na jornada de enfrentamento da aids.

Não só o medo da doença faz com que a família mantenha o segredo, mas o medo da discriminação social, e, sobretudo, o medo da perda e do afastamento dos amigos e dos familiares (Sousa et al 2004).

Como elucidado por Sacardo (2001), o papel da família, na visão dos entrevistados, é de que ela deva compartilhar do seu segredo, em virtude do papel de ‘cuidador' que a família exerce. Os familiares são considerados ailados no processo de adoecimento, cura e tratamento, e desta forma, há pouca expectativa em relação à manutenção da privacidade das informações entre si e a família nuclear (Sacardo, 2001).

O apoio familiar é baseado na solidariedade entre os membros da família, caracterizando estar junto "durante uma situação na qual há a perda do bem-estar", de adoecimento, ou fazer algo para poder ajudar (Sacardo, 2001). 
O papel da família também está associado à expectativa de proporcionar um sentimento de segurança, proteção, diminuindo o sentimento de vulnerabilidade provocado pelo adoecimento" (Sacardo, 2001).

Destaca-se a necessidade de que a família nuclear, que possui maior proximidade e intimidade com o indivíduo portador do HIV/AIDS, possa ter acesso às suas informações privativas. Destaca-se ,ainda, a questão do estigma relacionado à doença como fator essencial para limitar ao mínimo o número de pessoas que têm conhecimento do diagnóstico positivo para o HIV (Sacardo, 2001).

A questão da proximidade entre os familiares parece ser algo determinante, na medida em que há um limite entre os familiares mais distantes e os parentes mais próximos do doente (Sacardo, 2001).

Fatores como a identificação com o semelhante, a pressão exercida por terceiros, a dificuldade de mentir quando questionadas e a preocupação com a transmissão do companheiro, também configuram condições importantes para que a mulher abra ou não sua privacidade.

O medo do preconceito é muito presente no cotidiano dessas mulheres, e viver na luta pela vida torna-se mais complexo quando se trata de uma doença tão estigmatizante. Advindas deste preconceito, várias condições levam essas mulheres a não revelar seu diagnóstico às pessoas, como o medo de represálias de ex-parceiros sexuais, da exposição, de não conseguirem apoio para enfrentamento da doença, de rejeição e até mesmo de disseminação da informação.

Acredita-se que o receio de desvelar o diagnóstico reside no temor quanto ao julgamento social, ou seja, há o medo da humilhação, o medo da vergonha eo medo 
da culpa, tendo em vista que ainda hoje a aids é sinônimo de exclusão social (Sousa et al, 2004)

O indivíduo possuidor da doença é colocado dentro de um grupo de pessoas que é estigmatizado pela sociedade, por isso, ante a pressão social, utilizase do segredo como forma de enfrentamento para manter a sobrevivência do grupo, pois o adoecer não é uma situação vivida por ele, mas também pelos familiares, visto que é fonte de inquietações, dilemas éticos, ansiedades, gerando conflitos para toda a família (Sousa et al 2004).

O segredo, que é uma forma de ocultamento da doença entre os familiares, é uma expressão de entendimento de uma situação vivenciada e pode estar relacionado aos medos com que se defronta a família da experiência de ter um dos seus integrantes acometido pela aids (Sousa et al 2004).

Outras condições encontradas que levam as mulheres a não contar seu diagnóstico a outras pessoas foram o estabelecimento de um pacto de silêncio com alguém (neste caso específico companheiro), a possibilidad de se utilizar de estratégias para a manutenção do segredo, o sentimento de não querer que outros sintam pena, o medo de relações de afeto já estabelecidas, o envolvimento de filhos, principalmente, menores de idade e o fato puro e simples de preferiremguardar para si o seu segredo.

Às vezes as reações das pessoas infectadas pelo HIV/AIDS, de seus familiares e dos profissionais de saúde envolvidos são paradoxais. Esse paradoxo se apresenta de forma quase constante associado à falta de informação ou orientação, desde o momento da busca de ajuda para o diagnóstico, perpassando pelo impacto do diagnóstico e nas atitudes após o recebimento do resultado (Stefanelli et al, 1999). 


\subsection{COMPARTILHANDO O SEGREDO COM OS PROFISSIONAIS DO PSF: A ABERTURA (OU NÃO) DO DIA GNÓSTICO DE HIV/AIDS}

Decompondo os discursos das mulheres entrevistadas com HIV/AIDS em relação à abertura da privacidade, ou seja, o compartilhamento da informação sobre o diagnóstico com a equipe de PSF chegou-se ao seguinte resultado, identificado no Quadro 4 abaixo.

Quadro 4: As condições que levam as mulheres a abrir (ou não) sua privacidade sobre a informação sobre o diagnóstico de infecção para o HIV aos profissionais do PSF.

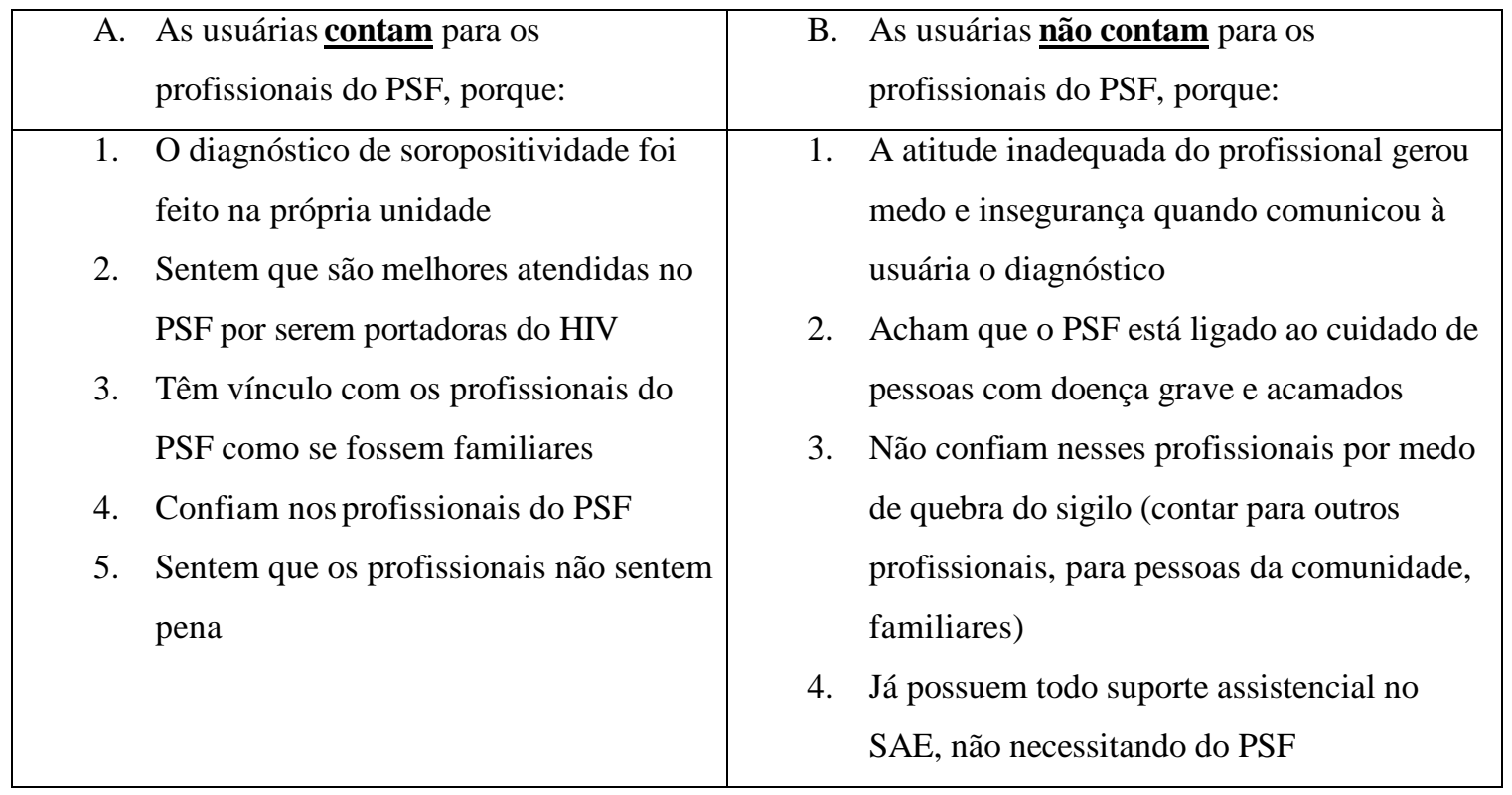

\section{A. CONTAM}

\section{A.1. O diagnóstico de soropositividade foi feito na própria unidade}

Na realidade como o diangnóstico de soropositividade foi realizado na própria unidade de PSF, já houve a abertura da privacidade em relação à informação. 
Três das entrevistadas neste estudo tiveram seu diagnóstico realizado numa Unidade Básica de Saúde por uma equipe de PSF. Duas delas, durante o pré-natal e uma quando procurou por uma ACS para realizar o teste anti-HIV.

As ações em HIV/AIDS no PSF voltam-se de um modo geral a ações de diagnóstico precoce, praticamente se restringem ao pré-natal e ao planejamento familiar, sendo obrigatória a abordagem e o oferecimento da testagem nestas situações (Silva et al, 2005).

Quando o diagnóstico foi realizado por uma equipe de PSF, pelo menos um membro dessa equipe toma conhecimento do segredo. Portanto, nesses casos não foi o fato de abertura do segredo, mas sim, compartilhamento do segredo por ocasião do diagnóstico. Pode ser que a mulher infectada procure outros membros da equipe e revele o segredo, ou também pode ser que por motivo de tratamento, outro membro da equipe venha a tomar conhecimento desta informação.

Abaixo, verifica-se um trecho de uma entrevista, na qual a mulher relata como foi realizado seu diagnóstico de soropositividade na própria unidade de saúde:

“Tem uma agente de saúde, e, foi assim, eu falei com ela que queria fazer exame, né? E não tinha como fazer exame naquele dia, aí ela falou pra mim, ela foi e falou, e... ela foi conversar com o médico, né? Pra mim ta lá 7 horas da manhã, pra mim conversar com o médico. Aí, eu fui no outro dia de manhã, aí ela... aí depois ela falou com o médico, o médico foi pedir o exame. Aí eu colhi no mesmo instante. Aí ficou, que quando saísse o resultado, ela mandava me avisar, aí ela foi, então ficou assim, se o resultado fosse sim, mandava me chamar. 
Aí eu fiquei pensando, falei: - Ah, não vai mandar me chamar, vai dar negativo, né? Aí, ela mandou me chamar.” - Safira

Como se pode perceber a ocasião do diagnóstico ocorreu quando a própria usuária buscou o atendimento para realização do teste anti HIV.

É importante que este momento de procura pelo exame a mulher receba apoio no aconselhamento pré e pós-resultado, para que não seja simplesmente encaminhada a um serviço de referência. Segundo Santos et al (2002a), o profissional que faz o atendimento deve promover ambiente confortável para que seja estabelecido um vínculo onde possam ser discutidos desde o significado do resultado na vida destas mulheres bem como questões específicas de prevenção, sexualidade e qualquer questão relacionada à saúde reprodutiva da mulher.

\section{A.2. Ela sente que é melhor atendida no PSF por ser portadora do HIV}

As mulheres contam à equipe do PSF sobre sua condição quando sentem que serão acolhidas nas suas demandas.

Em um estudo sobre satisfação dos usuários em relação ao PSF, Gomes e Torres (2003) constataram que a maioria das famílias atendidas estava satisfeita com o serviço prestado pela equipe do PSF e pela unidade de saúde. No entanto, é interessante que uma das entrevistadas avaliou que é melhor a qualiçde do atendimento exatamente por ser ela uma portadora do HIV, dizendo que suas necessidades de assistência médica, de enfermagem e de exames são atendidas com rapidez.

“Eu percebo que eu tenho uma... Eu sou diferenciada lá, no posto.

Porque quando assim, já qualquer coisa que me acontece, assim, 
porque eu tenho problema de pressão alta, então se eu tiver que passar no médico, alguma coisa assim, eu consigo passar não tem aquele negócio de: - Ah tem que marcar tal dia - Eu chego e falo diretamente com o médico, daí ele já me atende. Num ponto foi ruim, outro ponto não sei se foi isso, né, que melhorou. Então assim, eles me tratam super bem. Tem a enfermeira lá também, qualquer coisa assim que eu chego e falo com ela, nossa! Ela já resolve rapidinho, não deixa pros outros, então as pessoas falam que é o jeito que eu chego e converso, né, com eles, mas eu acho que começou a me tratar melhor do que trata os outros.” - Safira

Em relação aos ACS, vale ressaltar que Fortes e Spinetti (2004) constataram que o contato freqüente com os usuários faz com que estes, muitas vezes, revelem seus segredos aos ACS, abrindo parte de sua privacidade em razão de que isso possa facilitar seu acesso ao serviço de saúde.

\section{A.3. Tem vínculo com os profissionais do PSF como se fossem familiares}

O acolhimento e apoio recebido pelos profissionais da equipe de PSF é uma condição importante para que haja a abertura da privacidade.

O PSF possui um caráter humanista que modifica a condição vivida por muitos anos no sistema de saúde, já que transforma a relação impessoal de tratamento pontual, geralmente de caráter curativo, em uma perspectiva de ampliação do atendimento que olha o paciente em sua totalidade e realiza o acompanhamento da pessoa e não da doença. (Gomes e Torres, 2003). 
O traço marcante na estratégia do PSF, que a distingue de outras, refere se à relação interativa que estabelece entre os profissionais e a comunidade (Gomes e Torres, 2003).

Muitas vezes a relação com o profissional é comparada a vínculos familiares. “(...) se elas são médicas, enfermeiras, elas estão acostumadas, elas não iam me dar as costas. A enfermeira, eu tinha certeza que ela não ia me dar as costas. E por isso hoje eu tenho ela como uma irmã. A irmã me deu as costas, quer dizer, as minhas irmãs de sangue me deram as costas e ela não. Eé isso... ela, a ACS.”-- Aysha

\section{A.4. Confiam nos profissionais do PSF}

Uma condição que leva as mulheres a abrirem a privacidade sobre as informações é a confiança estabelecida entre as usuárias e os profissionais.

Um dos elementos que conduz à confiança do paciente nos trabalhadores de saúde é o conhecimento do direito à privacidade e, na abertura desta, o dever que os mesmos têm de não revelar os segredos que lhe foram confiados no exercício da profissão, mesmo aquelas desconhecidas pela própria usuária (Almeida e Munoz, 1993).

"A única pessoa que eu fiz assinar, que se falasse eu colocava ela presa, foi a ACS. Ela falou: - não, lógico, a gente não tem esse direito-. Ela toda a vida me passou confiança, em nenhum momento eu desconfiei dela." - Aysha

É imperativo que o direito ao sigilo seja explicitado para a usuária do serviço, pois reforçando a confiança, esclarecendo as dúvidas e deixando claro seus direitos como usuária, o vínculo e a credibilidade dos profissimais são reforçados. 
Em seu estudo, Fortes e Spinetti (2004) constataram que existe, por parte dos ACS, a preocupação com o princípio ético da privacidade e a necessidade da manutenção do sigilo profissional.

\section{A.5. Sentem que os profissionais não sentem pena}

Para as mulheres soropositivas ao HIV abrirem sua privacidade há condição de que os profissionais não sintam pena. Este sentimento de pena faz com que elas se sintam de alguma forma inferiorizadas.

“Então, assim, às vezes converso com ela, eu não sei. Ela me trata assim normal, não tem aquele negócio assim de... Como eu falei, né? Não teve aquele negócio assim de: - Aí, coitada, tal. - Então foi normal, ela me trata normal." - Safira

\section{B. NÃO CONTAM}

\section{B.1. A atitude inadequada do profissional gerou medo e insegurança quando comunicou à usuária o diagnóstico}

A atitude inadequada do profissional dos diferentes serviços de saúde pode comprometer a decisão sobre a abertura da privacidade à equipe de PSF.

No exemplo abaixo, o profissional gerou medo e insegurança quando comunicou à usuária o diagnóstico de soropositividade. Vale destacar que a situação ocorreu durante o atendimento do pré-natal dizendo "que a criança nasceria com problemas e que seria melhor realizar o aborto". 
No início dos anos de 1990, as mulheres infectadas pelo HIV evitavam a gravidez ou podiam ser sugestionadas a abortar, já que se pensava que o prognóstico delas e de seu concepto eram ruins. Hoje, sabe-se que a infecção pelo HIV não afeta a fertilidade, que a gravidez não acelera o desenvolvimento da doença e que a probabilidade de transmissão vertical se reduz a $2 \%$ com a utilização de medidas preventivas (supressão da amamentação, nascimento por cesárea, tratamento com antiretrovirais etc.) García-Sanchez (2004).

“Aí estava em greve lá, o médico ligou no celular da minha irmã, que eu não tinha telefone ainda na época, aí pediu para mim ir lá urgente. Estava eu e meu marido, ficamos desempregados, nós dois, aí ele falou para mim - olha, só falta ser o que eu estou pensando -, falei - não, não tem como. Aí a gente chegou lá, o médico não deixou ele entrar, o médico estava me esperando, não deixou ele entrar na sala, eu entrei e ele falou - 'Olha, você está com HIV ..' -, que eu já tinha feito exame lá e - '... Você está com HIV e você vai ter que tirar seu filho, porque senão o filho ou filha vai ser infectado e não vai ser uma criança saudável, tudo ...' Eu saí de lá em desespero, né?”--Dalila

\section{B. 2. Acham que o PSF está ligado ao cuidado de pessoas com doença grave e acamados}

Uma das usuárias referiu acreditar que o PSF faz acompanhamento de pessoas com doenças graves e acamados e que ela não necessitava de assistência, pois estava bem. Essa situação caracteriza a falta de conhecimento que por vezes se tem acerca dos atendimentos e serviços realizados pelas equipes de PSF. 
A proposta do PSF prevê o desenvolvimento de ações de promoção à saúde, prevenção, de cura de doenças e reabilitação, tanto em nível individual quanto coletivo, por meio do trabalho de uma equipe multidisciplinardedicada à saúde dos indivíduos, da família e da comunidade (Machado apud Silva et al, 2005). No entanto, persiste a idéia de que os serviços de saúde respondem às demandas por assistência aos doentes, com pouca ênfase a prevenção das doenças e promoção da saúde.

“Não sei, porque eu trabalho o dia todo. Mas tem, sei que tem, porque tem vizinhos lá... eles vão fazer visita quando a pessoa está doente, que não podem ir até o posto, eu sei que tem, ouço falar muito bem, mas eu nunca tive contato e espero não precisar, para não ter ninguém lá...” Jade

\section{B.3. Não confiam nesses profissionais por medo de quebra do sigilo (contar para outros profissionais, para pessoas da comunidade, familiares)}

As usuárias não abrem sua privacidade em relação à informação sbre sua soropositividade quando há falta de confiança nos profissionais de saúde, isto acontece por medo da quebra do sigilo.

Apesar de o sigilo ser preconizado pelos códigos de ética profissional, a sua manutenção é bastante complexa e, às vezes, é quebrado, particularmente, quando refere-se a doenças de notificação compulsória (Almeida e Munoz, 1993). Os autores ainda ressaltam que a relação profissional de saúdepaciente, na maioria das vezes, é baseada na confiança e no respeito mútuos. 
O medo de que o sigilo seja quebrado é expresso principalmente em relação ao ACS, por este morar na área de abrangência na qual atua, sendo muitas vezes vizinho e até membro da família em contraposição ao que referem os ACS entrevistados, no estudo de Fortes e Spinetti (2004)

“Também não contei. Que a agente comunitária ela mora lá na mesma rua que a minha, eu pensei - não, é melhor também eu não contar-, eu não sei também como vai ser a reação dela. Apesar que ela é muito legal, até arrumou uma fisioterapia para meu marido, mas eu não confio de contar, sabe? Não confio para contar para ninguém. Eu acho que se eu contar a pessoa vai ter aquele preconceito, de longe mas vai ter. Vai tratar eu diferente, sabe, então eu prefiro não contar (...) eu não sei como pode ser a reação dela, se ela pode contar para alguém. Então eu acho melhor não falar." - Selena

\section{B.4. Já possuem todo suporte assistencial no SAE, não necessitando do PSF}

Em seu estudo, Silva et al (2005) destacam que os discursos dos profissionais relativos ao atendimento em HIV/AIDS revelam ênfase no encaminhamento para os serviços especializados, desvinculandose os usuários da unidade básica e transferindo-se a responsabilidade pelo acompanhamento (Silva et al, 2005).

Da mesma forma que os profissionais, as muheres entrevistadas elegeram o serviço especializado como o local onde é oferecido todo o suporte assistencial de que necessitam, não havendo necessidade de abrir sua privacidade à equipe de PSF. As usuárias avaliaram positivamente o serviço especializado 
“Eu gosto daqui, né?Aqui já aprendi a conviver com todos, todos aqui aceitam a gente muito bem. E assim, como também tenho convênio eu prefiro não ir lá. Aqui eu acho que é o lugar mais ideal para meu caso, para o caso da minha filha, né? Então prefiro não ir lá. (...) Ela é atendida aqui, desde que ela nasceu, ela tinha uma semana. Ela sabe, a agente de saúde sabe que eu não vou lá mesmo porque eu freqüento aqui. Ela é atendida aqui, cada três meses ela faz exames e eu também. E qualquer tipo de coisa, mesmo tendo convênio, como tem a pediatra dela aqui, que acompanha ela desde que ela nasceu, então eu tenho mais confiança em trazer ela aqui. A menos que seja um caso de emergência e procure outro lugar, mas se não for eu prefiro vir aqui." -- Dalila

Há a necessidade de desmistificar a idéia de que as pessoas infectadas pelo HIV/AIDS devem ser acompanhadas apenas pelos serviços especializados, e que serviços de atenção básica não tem a oferecer assistência adequada.

Diante dos resultados obtidos, na intenção de identificar quais as motivações das mulheres soropositivas ao HIV/ AIDS para abrir a privacidade de suas informações para a equipe de PSF, destacamos que:

O HIV/AIDS, especificamente em mulheres, traz grandes desafios à sociedade e aos serviços de saúde. Esses desafios se referem, especialmente, ao rompimento de preconceitos enraizados no cotidiano e nas significações sobre o HIV. 
Villela (2003) aponta que os serviços de saúde, em especial na atenção básica, podem contribuir com medidas para o enfrentamento da epidemia do HIV/AIDS entre as mulheres.

Verificou-se que o PSF configura um serviço com grande potencial para o atendimento dessas mulheres, principalmente, nas questões relacionadas ao seu processo saúde-doença no cotidiano. Já que o PSF trabalha na comunidade, em especial, juntamente as famílias, devese compreender os processos pertinentes às relações familiares e comunitárias das mulheres portadoras do HIV/AIDS.

Algumas pessoas têm uma representação da aids pautada no preconceito e no medo causado pela discriminação dos próprios funcionários do estabelecimento de saúde. A defesa do segredo se justifica pelo alto índice de desinformação da população em geral e também de alguns trabalhadores da saúde, que resulta em uma desconfiança do paciente de que os funcionários fiquem sabendo do seu diagnóstico de soropositividade do HIV e possam disseminálo (Sacardo, 2001).

Verificou-se neste estudo que as mulheres abrem a privacidade das informações ao HIV à equipe de PSF quando o diagnóstico das informações foi feito na própria unidade, principalmente porque, neste caso, a privacidade já foi aberta a pelo menos um dos membros da equipe. E a necessidade de manter o sigilo, por parte dos profissionais de saúde, é primordial.

O PSF caracteriza-se pelo vínculo e pela responsabilização da equipe em relação às famílias de sua área, porém é necessário e estabelecimento de contratos de manutenção do sigilo e de estabelecimento de limites por parte das equipes em relação aos usuários (Zoboli e Fortes, 2004). 
Foi constatado que pode ser que essas mulheres soropositivas sintam que são melhor atendidas pelas equipes de PSF por serem portadoras do HIV/AIDS.

O vínculo com o profissional, ou seja, a confiança construída ao longo de uma vivência profissional, facilia que a mulher sinta a confiança necessária para abrir sua privacidade em relação ao diagnóstico de soropositividade e, ao contar, espera que seja mantido o sigilo profissional de suas informações.

Cabe considerar que o contexto dos serviços de saúde caracteriza-se pela confiança depositada pelo usuário na instituição, através dos membros que a compõem. Ao ser negligenciada a confiança, a revelação de informações privativas pode afastar o usuário do serviço, perdendo-se a oportunidade de negociar e trabalhar a dificuldade de compartilhar (Sacardo, 2001).

As pacientes revelam-se agentes ativos nas relações que estabelecem com os profissionais, adotando estratégias que lhes garantam um vínculo empático e, até certo ponto, com mais autonomia sobre o tratamento. Avaliam os profissionais segundo critérios, tais como, capacidade técnica, disponibilidade para a escuta, afetividade, paciência e clareza nas informações transmitidas (Aguiar e Simões Barbosa, 2006).

Sacardo (2001) verificou que existe uma expectativa clara, tanto de um grupo de pessoas hospitalizadas quanto do grupo de pessoas não hospitalizadas, de preservação da privacidade das informações em relação aos profissionais de saúde e que devem limitar seu acesso àquelas informações que sejam essenciais ao desenvolvimento de uma assistência de qualidade ao usuário do serviço (Sacardo, 2001). 
Foi desvelado que as usuárias entrevistadas não contam ao PSF sua condição de soropositividade em várias condições. Numa delas houve atitude inadequada do profissional que informou o diagnóstico à usuária, gerando medo e insegurança.

Algumas mulheres passaram por situações constrangedoras, atitudes preconceituosas ao revelarem o diagnóstico. Estas experiências negativas podem levar ao isolamento (Vermelho et al, 1999).

Algumas mulheres referiram que já possuem todo suporte assistencial necessário aos seus cuidados no SAE e que por isso não vêem necessidade de atendimento em outras instituições de saúde.

Silva et al (2005) concluíram em seu estudo que não existe conhecimento sobre quem na população atendida pelo PSF é portador do HIV/AIDS e que não há demanda de assistência para as equipes de PSF, referindo que nunca houve este atendimento a usuários nesta condição. Tais apontamentos diferem dos resultados do presente estudo.

Em relação ao atendimento dos soropositivos ao HIV/AIDS pelos profissionais do PSF, Silva et al (2005) observaram que estes desconhecem a forma de acesso dos usuários e a rotina do SAE referente a quais as ações realizadas neste serviço. Uma informação básica a que os profissionais deveriam ter acesso seria quanto aos critérios de atendimento nesse serviço.

Questões além do manejo clínico da doença devem ser tratadas pelos serviços de saúde especializados, e da atenção básica também, é importante acoller e aconselhar essas mulheres, no manejo de suas vidas. Principalmente, nos aspectos que são afetados pela condição de soropositividade, como o convívio social, o trabalho, a família, o cuidado e o futuro dos filhos (Tunala, 2002). 
Como apontado por Zoboli e Fortes (2004), a proximidade e a convivência maior com os usuários do serviço no PSF traz à tona a atual inexperiência ao lidar com tal proximidade. E, por vezes, tenta-se mascarar a insegurança advinda da falta de experiência, prendendo-se a normas, procedimentos e rotinas do serviço. 


\section{CONSIDERAÇÕES FINAIS}

Seria importante incluir na agenda dos serviços que operam com PSF ações relacionadas à discussão de questões pertinentes ao viver com HIV/AIDS, a fim de diminuir os preconceitos existentes na comunidade.

Há necessidade de implementação de estratégias voltadas aos profissionais de saúde e da população em geral, para o desenvolvimento de novos olhares, despidos de preconceitos, às pessoas infectadas pelo HIV/ AIDS, principalmente mulheres. Pois ainda se trata de uma doença estigmatizante, principalmente, para os grupos de pessoas que apresentam estilos de vida considerados não saudáveis como os homossexuais, as prostitutas e os usuários de drogas injetáveis (Sacardo, 2001).

O PSF também poderia criar oficinas para discussão de informações básicas sobre ética juntamente à população, principalmente no que tange o sigilo profissional. Tal necessidade é destacada por Sacardo (2001), quando afirma que há escassez de momentos direcionados para discussão e reflexão com a população, nos quais se abordem os deveres dos profissionais de saúde em relação ao sigilo profissional, as implicações recorrentes da quebra do mesmo e o direito dos usuários à privacidade.

De acordo com Zoboli e Fortes (2004), seria recomendável a implementação de estratégias para apoiar a problematização das questões éticas, e faz-se necessária a criação de oportunidades para que os profissionais de saúde se empenhem em discussões de temas éticos, com a finalidade de proporcionar um ambiente de trabalho mais sadio, colaborativo e que permita a excelência técnica e moral da assistência prestada. 
Outras usuárias referiram que não abrem a privacidade de suas informações em relação ao diagnóstico de soropositividade ao HIV porque não confiam nos profissionais por medo de quebra do sigilo. Este fato pode ocorrer por falta de vínculo, desconfiança ou experiência anterior; de fato, é preciso trabalhar as questões relativas ao sigilo juntamente com os profissionais de saúde, a fim de se tornar consolidada uma atitude ética no desenvolvimento do cotidiano na atenção básica.

Há a necessidade de elaboração de estratégias que sensibilizem os profissionais para as questões relacionadas ao sigilo das informações das usuárias portadoras do HIV e usuários em geral, no PSF. Para isso pode-se lançar mão de estratégias como oficinas, palestras e cursos, para que se atinja tal aspiração.

Vale lembrar que os problemas éticos na atenção básica são, em sua maioria, constituídos por situações do cotidiano, por preocupações que permeiam a prática da atenção básica à saúde e não por situações dilemáticas. Mas, isso não significa que sejam menos importantes, porém, são distintos em relação aos problemas éticos do âmbito hospitalar (Zoboli e Fortes, 2004).

De acordo com os autores, as questões éticas na atenção básica, a seu modo, são amplas e complexas. E devem ter especial atenção, já que por serem menos dilemáticas podem não ser identificadas, colocando em risco o vínculo criado como base no PSF.

Destaca-se que há falta de conhecimento acerca das funções e atuações do PSF, verificou-se tal situação quando emergiu dos discursos que as usuárias pensavam que o PSF estava ligado somente ao cuidado de pessoas com doenças graves e acamados.

Seria interessante que o PSF mostrasse mais o trabalho desenvolvido na comunidade e que conseguisse disseminar ao maior número possível de pessoas, para 
que serve e a que se presta, especialmente, àquelas que não são atendidas por recusa, ou porque trabalham durante a semana em horário comercial, e encontram-se ausentes durante as visitas domiciliares dos ACS.

Os profissionais que atuam no PSF têm que exercer uma prática marcada pela humanização, pelo cuidado, pelo exercício da cidadania e baseada na compreensão de que as condições de vida e trabalho são as definidoras o processo saúde-doença dos usuários (Zoboli e Fortes, 2004). 


\section{REFERÊNCIAS BIBLIOGRÁFICAS}

1. Aguiar JM, Simões-Barbosa RH. Relações entre profissionais de saúde e mulher HIV +: uma abordagem de gênero. Cad de Saúde Pública, Rio de Janeiro; 2006; out.; 22 (10): 2112-2123.

2. Allen AL. Privacy in health care. In: Reich W. Enciclopedy of bioethics; 1995.

3. Almeida M, Munoz DR. Relação médicopaciente e paciente-instituição na AIDS: o direito à informação e à confidência; a discriminação, o abandono e a coerção. Rev Bioética- Simpósio AIDS e Bioética; 1993; 1(1).

4. Bagnara RO, Cardoso GM. Mulher, sexualidade e aids: reação comportamental frente ao diagnóstico positivo para o HIV. Cap 2 In: Cardoso GM, Braz E (org). O ser mulher na visão do enfermeiro. Cascavel: Coluna do Saber; 2005;100p.

5. Bardin L. Análise de Conteúdo. Lisboa: Edições 70; 1977.

6. Barroso MGT, Miranda CCL, Pinheiro PNC. A Aids sob o olhar da companheira contaminada. Rev Bras Enferm Brasília; 1998; jułset.; 51(3): 393-402.

7. Brasil, Ministério da Saúde. Boletim epidemiológico: aids e DST. $1^{\text {a }}-26^{\mathrm{a}}$ semanas epidemiológicas; 2006; jan-jun.; 3(1).

8. Bueno FS. Grande dicionário etimológico-prosaico da língua portuguesa: vocábulos, expressões da língua geral e científica - sinônimos, contribuições tupi-guarani. São Paulo: Saraiva; 1963.

9. Ferraz FC. A relação entre o profissional de saúde e o usuário de suas atenções, vista a partir do princípio da autonomia. In: Segre M. A questão ética e a saúde humana. São Paulo:Atheneu;2006; $1^{\mathrm{a}}$ ed, 272 p. 
10. Fortes PAC, Spinetti SR. O agente comunitário de saúde e a privacidade das informações dos usuários. Cad Saúde Pública; 2004; 20(5):13281333.

11. Fortes PAC, Zoboli ELCP org. Bioética e saúde pública, São Paulo : Centro Universitário São Camilo/Edições Layola; 2003; 167p.

12. Garcia-Sanchez, I. Diferencias de gênero em el VIH/sida. Gac Sanit.; 2004; 18(supl 2):47-54.

13. Gomes ACCN, Torres GV. Opinião das famílias atendidas pelo PSF em uma unidade de saúde da família do distrito oeste de Natal. Texto e contexto Enferm; 2003; out.-dez.; 12(4): 495-503.

14. Guerra MAT. Política de controle da aids de estado da saúde de São Paulo, período de 1983-1992. A história contada por seus agentes [mestrado] Universidade de São Paulo - Faculdade de Medicina. SãoPaulo; 1993.

15. Gracia D. Fundamentación y enseñanza de la bioética Santa Fé de Bogotá: El Buho; 1998.

16. Gryschek ALFPL. A política de qualificação da força de trabalho em enfermagem no Programa Municipal de DST e Aids de São Paulo: um desafio contínuo [doutorado]. Universidade de São Paulo - Escola de Enfermagem. São Paulo; 2001.

17. IBGE, Censo demográfico, Rio de Janeiro; 2000.

18. Lanno A. El manejo del secreto profesional com pacientes de sida. In: Fuenzalida-Puelma HL, Parada AML, La Vertu DS. Aportes de la éti ca y el derecho al estúdio del sida. Washington: Organización Panamericana de Salud; 1991; 291p.

19. Lopes MVO, Fraga MNO. Pessoas vivendo com HIV: estresse e suas formas de enfrentamento. Rev Latino-am Enferm, Ribeirão Preto; 1998; out.; 6(4): 75-81. 
20. Massarollo MKB, Sacardo DP, Zoboli ELCP. Autonomia, privacidade e confidencialidade. In: Oguisso T, Zoboli ELCP org. Ética e bioética: desafios para a enfermagem e a saúde. Barueri, SP: Manole; 2006 (Série enfermagem).

21. Parker R (org.). Políticas, instituições e AIDS: enfrentando a epidemia no Brasil. Jorge Zahar editor, Rio de Janeiro:ABIA; 1997.

22. Pessini L, Barchifontaine CP. Problemas atuais de bioética. $5^{\text {a }}$ ed. São Paulo: Loyola; 2000.

23. Pessini L, Barchifontaine CP. Bioética: do principialismo à busca de uma perspectiva latino-americana. In: Costa SIF, Garrafa V, Oselka G, coord. Iniciação à bioética. Brasília: Conselho Federal de Medicina; 1998. p. 81 98.

24. Pinheiro PNC, Vieira NFC, Pereira MLD, Barroso MGT. O cuidado humano: reflexão ética acerca dos portadores do HIV/AIDS. Rev Latino-am Enferm; 2005; jul-ago.; 13 (4): 569-75.

25. Porto JRR, Homero MNT, Luz AMH. Violence against woman and the female increase of HIV/AIDS incidence. Online Brazilian Journal of Nursing; 2003; Dec.; 2(3). Disponível em http://www.uff.brt nepae/objn203 portohomeroluz.htm

26. Potter VR. Vídeo conferência. O mundo da saúde. 1998; 22: 370-374. [apresentado no IV Congresso Mundial de Bioética; 1998 Nov 04-07; Tóquio].

27. Rasera EF, Japur M. Grupo de apoio aberto para pessoas portadoras do HIV: a construção da homogeneidade. Estud. psicol. (Natal)., Natal; 2003; 
8(1). Disponível em: <http://www.scielo.br/scielo.php?script=sci_arttext \&pid=S1413-294X2003000100007\&lng=pt\&nrm=iso>. Acesso em 19 jan. 2007.

28. Reich WT, org. Bioethics enciclopedya $2^{\mathrm{a}}$ ed. [CD ROM]. New York: Mac Millan Library; 1995. Privacy in Health Care.

29. Reyes MW. Infección por VIH: algunas consideraciones éticas. Cuad. Méd. Soc.; 1996; 37 (4).

30. Richter M. Preliminary assumpitions on the nature and extend of discrimination against peqle living with aids in South Africa interviews and a study of aids law project client files 19932001. [on line]. South Africa: AIDS Law Project; 2001. Disponível: http://www.alp.org.za/ resctr/rpaprs/misc/20010731_prmrnaed.doc Acesso em 18 ago. 2003.

31. Sacardo DP. Expectativa de privacidade segundo pessoas hospitalizadas e não hospitalizadas: um estudo bioético [mestrado] Universidade de São Paulo - Faculdade de Saúde Pública, São Paulo;2001; 125p.

32. Santos NJS, Buchalla CM, Fillipe EV, Bugamelli L, GarciaS, Paiva V. Mulheres HIV positivas, reprodução e sexualidade. Rev Saúde Pública; 2002; ago.; 36 (4 supl): 12-23 (a)

33. Santos NJS, Tayra A, Silva SR, Buchalla CM, Laurenti R. A aids no estado de São Paulo. As mudanças no perfil da epidemia e perspectivas da vigilância epidemiológica. Rev Bras Epidemiol, São Paulo; 2002; dez.; $5(3)(b)$

34. São Paulo Município. Boletim Epidemiológico de Aids/HIV, DST, hepatites B e C do Município de São Paulo; 2006. 
35. São Paulo Município. Boletim Epidemiológico de Aids/HIV, DST, hepatites B e C do Município de São Paulo. Setembro, 2004.

36. São Paulo Município. Boletim Epidemiológico de Aids/HIV, DST, hepatites B e C do Município de São Paulo. Setembro; 2005.

37. São Paulo. Secretaria de Estado da Saúde. Coordenação dos Institutos de Pesquisa. Ações de prevenção e assistência às DST/AIDS na rede de atenção básica à saúde do estado de São Paulo; 2003.

38. Turienzo G, Mesquita F. Um panorama da luta contra a epidemia de DST/AIDS na cidade de São Paulo. In: Mesquita F, Souza CR (org). DST/AIDS, a nova cara a luta contra a epidemia na cidade de São Paulo. São Paulo, Prefeitura do Município. Secretaria Municipal de Saúde. . São Paulo: Raiz da Terra; 2003; abr.; p.13-17.

39. Schaurich D Padoin SMM. Do cuidado da mulher: questões de gênero e sua incorporação no contxto do HIV/AIDS. Esc Anna Nery Rev Enferm 2004 abr; 8 (1): 101-8.

40. Selli L. Bioética na enfermagem. São Paulo: Unisinos; 1999.

41. Silva LMS, Guimarães TA, Pereira MLD, Miranda KCL, Oliveira EN. Integralidade em saúde: avaliando a articulação e a co-responsabilidade entre o programa saúde da família e um serviço de referência em HIV/AIDS. Epidemiologia e Serviços de Saúde; 2005; 14(2): 97-104.

42. Sousa AS, Kantorski LP, Bielemann VLM. A Aids no interior da famíliapercepção, silêncio e segredo na convivência social. Acta Scientiarum. Health Sciences, Maringá; 2004; 26(1):1-9. 
43. Stefanelli, MC, Gualda DMR, Ferraz AF. A convivência familiar do portador do HIV e do doente com aids. Família Saúde e Desenvolvimento; 1999; 1(1/ 2):67-79.

44. Stefanelli, MC. Comunicação com o paciente: teoria e ensino. $2^{a}$ ed.. São Paulo: Robe; 1993.

45. Tunala LG. Fontes cotidianas de estresse entre mulheres portadoras de HIV. Rev Saúde Pública; 2002; 36(4 Supl): 2431.

46. Vermelho LL, Simões-Barbosa RH, Nogueira SA. Mulheres com AIDS: desvendando histórias de risco. Cad Saúde Publica; 1999; 15: 36979.

47. Villela W. Reelaborando a agenda sobre AIDS e mulheres. Divulgação em Saúde para Debate, Rio de Janeiro; 2003; dez.; 29:61-72.

48. Villela W. Oficinas de sexo mais seguro para mulheres: abordagers metodológicas e de avaliação. São Paulo; NEPAIDS; 1996. 76 p.

49. World Health Organization - WHO. Prevention of mother to child transmission of HIV. Selection and use of nevirapine; 2001.

50. Xavier IM. Cidadania, Gênero e Saúde: A mulher e o enfrentamento da AIDS. Rev Enferm UERJ; 1996 (extra):89-100.

51. Zoboli ELCP. Bioética e atençäo básica: um estudo de ética descritiva com enfermeiros e médicos do Programa Saúde da Família [doutorado] Universidade de São Paulo: Faculdade de Saúde Pública. São Paulo; s.n; $2003 ; 251$ p. (b)

52. Zoboli ELCP. Bioética gênese, conceituação e enfoques. In: Oguisso T e Zoboli ELCP, org. Ética e Bioética: desafios para a enfermagem e a saúde. São Paulo: Manole, 2006. (a) 
53. Zoboli ELCP, Fortes PAC. Bioética e atenção básica: um perfil dos problemas éticos vividos por enfermeiros e médicos do Programa Saúde da Família, São Paulo, Brasil. Cad saúde Pública, Rio de Janeiro; 2004; 20(6):1690-1699. 


\section{APÊNDICE}

\section{Entrevistas}

\section{Safira 001}

Entrevistadora - P: Então Safira, conta pra mim, por favor, como foi pra você quando você soube que estava infectada pelo HIV?

Entrevistada - R: Foi difícil, né! Porque eu tinha planos assim... de... ter outro filho e tal, mas foi complicado, né. Porque já veio a coisa do meu olho, aí é, depois do problema do olho que eu fiquei sabendo, né. A médica lá em cima ela me chamou por causa que eu queria fazer um exame, por fazer mesmo, aí ela falou que se tivesse positivo ela me mandava me chamar. Então foi difícil, até hoje ainda não entrou na minha cabeça, assim mesmo eu tend o CD 4 bem alto, que a médica me fala pra mim que eu tenho o CD 4 como se fosse de alguém que não tivesse o vírus, né! Eu não tomo remédio ainda, então eu, nossa, mas mesmo assim é difícil eu evito o máximo assim de pensar... No máximo, eu evito. Eu tomo2, é antidepressivo por dia de manhã, já pra... as vezes eu fico estressada porque quando eu começo a pensar muito... Porque bem no primeiro momento a gente pensa que já vai morrer. Sabe, assim, falam das pessoas rejeitarem meu marido também é, que apareeu primeiro né. Então foi muito complicado. Eu participo assim do grupo de manhã de adesão, $5^{\text {a }}$ feira, né. Então me ajuda bastante, o grupo de manhã, me ajuda bastante. E aí eu tiro minhas dúvidas. Aí a gente vai vendo que não é uma coisa assim... bicho desete cabeças, é uma doença só que não tem cura e tem como não fazer com que ela mata a gente, né! Mas é muito complicado conviver com uma doença que não tem cura é terrível. Terrível, terrível mesmo, viu, é. 
P: Você contou pra alguém, como foi pra você quando você soube, você contou pra alguém?

R: Contei eu contei pra duas amigas, contei pra minha cunhada é... pra irmã do meu marido, contei pra minha família a minha mãe e os meus irmãos né. Assim eles falam assim pra mim: Ah, mas tem tanta gente que tem ess doença, essa doença não mata. Mas só de saber assim que ta com um bicho, assim no corpo sabe, dá uma agonia. Hoje assim eu não agüento ver sangue, quando só de... eu vou escovar os dentes e sai sangue. Nossa! Já fico até com medo, eu acho que ta cheio de bicho, é aquela coisa que... Então, eu contei pra eles todos, eles me deram a maior força, falaram e sempre falam a mesma coisa.

Uma coisa assim que mata falam pra eu, que é pra eu me cuidar. Não tem, comigo eles não tem aquele preconceito que eu sei que eles teriam né. A família está mais, ta mais assim ligada comigo. Me liga todos os dias, me ajuda do jeito que pode. Então, num ponto foi ruim por causa de saber que eu tenho a doença, mas no outro ponto me fez ver outras coisas que eu não vejo, que eu não vice antes né. Eu não era tão ligada assim a minha mãe, hoje eu já sou mais ligada a ela.

P: É assim, como foi contar pela primeira vez, pra primeira pessoa que você contou que estava infectada? O que você pensou nessa hora?

$\mathrm{R}$ : Ah, eu pensei assim que poderia me ajudar de alguma forma. Então eu tipo, no primeiro momento, é o que a gente quer ouvir né, é uma assim, palavra assim de amigo, no primeiro momento foi isso. E realmente, eu consegui:- Não, mas não é assim, hoje tem cura, o negócio não é igual antigamente... Cura assim, entre aspas. Então não é igual antigamente que tinha aqueles remédio horrível, hoje já é mais fácil. - Não é por isso que você vai morrer. Então foi assim... hoje mesmo 
quando eu sinto vontade de conversar com alguém, eu não tenho problema assim de chegar e falar eu sou soropositiva, sabe eu não tenho problema. Eu chego e falo numa boa. Mas aí eu fico pensando assim se fosse alguém que fosse falar pra mim como seria a minha reação. Será que eu ia sair de perto, será que eu ia ser do mesmo jeito e se não fosse.

Então é um preconceito, existe na cabeça de todo mundo, não tem jeito.

P: Qual foi essa primeira pessoa que você contou?

R: Uma colega, a primeira foi uma colega.

P: Você guarda segredo sobre seu diagnóstico para alguém?

R: Depende da pessoa, eu guardo. Assim, só conto mesmo pras pessoas que já sabem, né. Mas eu preferi não contar mais por causa do meu marido. Porque na verdade ele nem sabe eu essas pessoas sabem. Ele acha eu quem sabe só eu, ele e a minha cunhada. Mesmo a minhafamília ele acha que não ta sabendo porque... não sei se o preconceito ta dentro da cabeça dele, porque ele já... já conheceu pessoas que tem, que já teve esse problema, que morreu né. Então ele viu como foi o preconceito que essas pessoas sentiram, né: Então ele tem esse, ele fala que não quer que as pessoas sintam pena, então ele não quer que ninguém fique sabendo. Então é um pouco complicado. Eu por mim, nem ligou muito assim, entendeu? Não sei se é porque eu evito o máximo de colocar na minha cabeça de, eu tenho isso, tenho aquilo. Porque eu tento me preocupar com as outras coisas mesmo, mas foi assim... Eu me sinto muito bem quando eu falo a respeito, acho. Eu me sinto mais em paz, dividindo alguma coisa que perturba, né!

P: Você já morava no bairro onde que você mora hoje quando você soube do diagnóstico, né? 
R: Isso,

P: Ser HIV positiva interfere em alguma coisa na sua convivência no bairro onde você mora?

R: Não, muito pelo contrário. O pessoal me trata do mesmo jeito. Eu acho que mudei com as pessoas. Eu trato mais assim... Eu sempre tratei todo mundo com respeito mas eu hoje, eu vejo com outros olhos, sabe? Ninguém nunca sabe o dia de amanha, se vai precisar ou não. Mas tratam do mesmo jeito assim, hoje eu vejo eles com outros olhos assim, porque a gente sempre se diminui assim quando tem um problema sério. Mas não mudou nada, do mesmo jeito mesmo!

P: Como você se sente com as pessoas, você me falou que vê as pessoas com outros olhos. Me explica.

$\mathrm{R}$ : Ah, eu assim, porque eu acho, eu me sinto pequeninima agora, entendeu? Vivendo esses problemas, entendeu? É uma coisa que ninguém pode ficar sabendo. Porque, igual meu marido fala já vai ficar com pena da gente, vai achar que a gente vai... fica aquele medo. Inclusive, tem um rapaz lá que ele falou que fiou sabendo que estava doente, uma outra pessoa que falou pra mim, aí ia falando: - "Não, não pode chegar perto dele”. E um monte de coisa que eu fiquei assim, nossa mas já pensou se eu conto, quer dizer, todo mundo vai sair me apontando. Então, é complicado. Mas eu me sinto assim pequenininha mesmo, assim quando... Quando eu to conversando com ele, e que eu lembro desse problema, então, eu me sinto pequenininha. Mas ninguém sabe se ele também tem, só que tem aquele negócio de que ninguém gosta de comentar, né? Então é complicado. As pessoas assim que sabe que eu tenho me trata normal. As vezes nem sempre, as vezes, se... Igual, o tempo ta frio, se eu fico só de camiseta, daí eles falam assim:- Ah, vai colocar uma blusa de 
frio!(ri). Aí eu não sei se ta é querendo cuidar de mim, ou se já pensam que eu vou ficar doente, entendeu? Então fica um pouco... Eu fico assim, com medo de tocarem no assunto junto com meu marido, quando meu marido ta perto, então já fico: - Ai meu Deus, só o que faltava? Porque que ele não sabe que a gente sabe né! Então, eu fico com medo nesse ponto, mas do contrário não, normal! Mas sabe que é uma coisa que eu mesma pensava que nunca ia acontecer comigo, é impressionante, quando a gente acha que nunca vai acontecer [pausa longa] acaba antecendo.

P: Você contou pra alguém da equipe do PSF lá da Vila Dalva sobre seu diagnóstico?

R: Tem uma agente de saúde, e, foi assim, eu falei com ela que queria fazer exame, né! E não tinha como fazer exame naquele dia, aí ela falou pra mim, ela foi e falou, e... ela foi conversar com o médico, né! Pra mim ta lá 7 horas da manhã, pra mim conversar com o médico. Aí, eu fui no outro dia de manhã, aí ela... aí depois ela falou com o médico, o médico foi pedir o exame. Aí eu colhi no mesmo instante. Aí ficou, que quando saísse o resultado, ela mandava me avisar, aí ela foi, então ficou assim, se o resultado fosse sim, mandava me chamar. Aí eu fiquei pensando, falei:Ah, não vai mandar me chamar, vai dar negativo, né! Aí, ela mandou me chamar. Então, assim, as vezes converso com ela, eu não sei. Ela me trata assim normal, não tem aquele negócio assim de... Como eu falei, né. Não teve aquele negócio assim de: - Aí, coitada, tal. - Então foi normal, ela me trata normal. Eu tenho assim... Eu percebo que eu tenho uma... Eu sou diferenciada lá, no posto. Porque quando assim, já qualquer coisa que me acontece, assim, porque eu tenho problema de pressão alta, então se eu tiver que passar no médico, alguma coisa assim, eu consigo passar não tem aquele negócio de: - Ah tem que marcar tal dia - Eu chego e falo diretamente 
com o médico, daí ele já me atende. Num ponto foi ruim, outro ponto não sei se foi isso, né, que melhorou. Então assim, eles me tratam super bem. Tem a enfermeira lá também, qualquer coisa assim que eu chego e falo com ela, nossa! Ela já resolve rapidinho não deixa pros outros, então as pessoas falam que é o jeito que eu chego e converso, né, com eles, mas eu acho que começou a me tratar melhor do que trata os outros. Eu não sei, se é por causa desse problema, não sei, mas foi legal conversar com ela.

Esses dias estava até fazendo caminhada 3 vezes por semana, eu tava fazendo caminhada com ela, aí eu dei uma parada, agora que ta frio. Eu fico com preguiça de sair da cama, de manhã. Daí eu dei uma parada.Mas eu sempre encontro com ela E, aí como é que você ta? - To bem - Aí, sei lá, me apeguei mais com as pessoas a esse respeito. Porque é sempre legal ter alguém pr conversar, pra conversar quando você ta querendo se "des sufocar". Porque as vezes dá vontade de sair correndo, se jogar dentro do mato. Assim... É terrível, mas com ela foi legal, conversar com ela.

P: Mais alguma coisa que você quer dizer que você sente.

R: Ah, assim... É que eu não sou tão difícil, né. Assim pra... Bom a minha filha não tem, né! Bom eu fiquei sabendo agora, já tem já, já vai fazer 1 ano. Então, é um pouco difícil, é... Porque tem que lutar, pra algumas pessoas. As vezes eu tenho vontade de trabalhar, como eu trabalhava antes, eu sempre gostei muito de cozinhar, né. Então é complicado, porque vou... Eu tenho psicólogo uma vez por semana quinta, e quando eu não venho, a médica já liga pra minha casa.- Ah, porque você não veio com a Márcia? - Com a infectologista eu passo a cada quatro meses, só pra fazer os exames. Então ela fala pra mim - Ah, você tem CD 4 que dá pra você vender, porque é bem alto! Imagina! Que você não sabe, isso não entra assim na 
cabeça, é uma coisa complicada, mesmo, de encarar. As vezes... meu marido fala assim: - Ah, eu evito o máximo de pensar! - Ontem ele veio aqui pegar uns resultados dos exames dele, o CD 4 dele subiu bastante. Então, eu falo, ele já toma remédio, eu fico no pé dele, por causa da comida, dos doces, vejo se ele ta se alimentando bem, então eu quero, eu fico cuidando dele e ao mesmo tempo não cuido tão bem de mim. Porque eu acho, eu penso assim, que não vai ser isso que vai me matar. Mas, as vezes, eu deixo... Eu fico um pouco pra baixo quando eu começo a pensar assim, aí me dá vontade, assim... Já de ficar doente logo, já morrer logo, não viver, acho que já vai acabar o sofrimento, mas não sei é muito confuso, sabe. Saber assim que ta com uma doença dessa. Ontem ele veio assim ver resultados uns exames. Andei discutindo aqui ontem a tarde com a... Porque ele acabou encontrando uma pessoa espalhar sair contando, então e muito complicado. As vezes, tipo assim, não é nem tanto as pessoas assim, do posto ficar comentando é, mas... As pessoas que a gente conhece... Que vê... Ele trabalha aqui perto, ele morre de medo de alguém lá ver ele entrando aqui, então, as vezes, ele acaba sofrendo preconceito muito grande. Ele acaba até falando deveria ter mais comerciais sobre isso na televisão, sair mais no jornal, que não é assim, pras pessoas começar a ver a gente, logo quando saiu a tuberculose, né. As pessoas tinham preconceito muito grande e... E ele tava até comentando a respeito disso falou. É ia ser legal, né. Porque aí, não vai ver a gente como um bicho. Porque se a gente tiver num lugar, igual eu falei pra minha irmã. Eu estava no shopping, fdei pra ela: - Se alguém escutar eu falando assim: - Ah, eu sou soropositiva: - É perigoso fechar o shopping. Ela falou assim: Lógico que não! - Eu disse: - Lógico que não, você que pensa. - As vezes é o ser humano, né! Uma cabeça, dentro não tem assim mção, a gente pensa muitas coisas 
em questão de minuto, né! Então é um pouco complicado! Eu... Igual... Eu to cuidando dessas crianças, ontem mesmo a minha colega perguntou, ela falou assim, se a mãe das crianças sabe, né. Eu falei não, não sabe, porque eu sei que se ela souber, ela não vai deixar as crianças. Então não é uma coisa assim, que a gente faz, mas ao mesmo tempo a gente pensa porque eu fiz. Então é complicado! A gente, se a gente for pensar bem, assim, se for ficar pensando 24 horas e você acaba ficando louco. Não tem como saber administrar tudo dentro da cabeça, a gente não consegue, não aceita. Por mais que a gente fica conformado... mas não tem como aceitar. É complicado, viu. [pausa longa]. Então mexeu muito comigo [pausa longa].

Nossa, a minha irmã fala assim:- Ah! Mas tem doença muito mais perigosa! - Mas então, se a pessoa fala assim: - Ah, eu tenho câncer. - As pessoas que tão ali em volta não vai ver ela assim, não vai ficar com medo, agora se fala:- Ah! Eu tenho aids. - Ninguém vai ter coragem de encostar. Vai ficar com medo de encostar e porque acha que já vai pegar. Então é uma coisa assim que eu mesma acho que se fosse comigo eu também reagiria do mesmo jeito. Porque eu acho que já faz parte do ser humano. Mas é complicado. Você achar que... aqui mesmo, as vezes, eu fico pensando... Tem os psicólogos, os médicos, não sei se eles tem os mesmos problemas, porque eles tratam a gente muito bem. Tem a psicóloga que eu passo, tem o psiquiatra, nossa eu considero eles como se eles fossem... Como se fossem da minha família mesmo. Sabe, nossa! Quando é pra mim vim aqui pra falar com eles, que eu tenho consulta, nossa, não vejo a hora de chegar aqui. Igual, eu vim fazer exame de sangue, igual, o médico vai entrar de férias aí eu acabo sentindofalta deles, a gente acaba se apegando, nossa tem me ajudado muito eles dois. Porque quando eu cheguei aqui eu mesmo com o CD 4 alto, mas eu cheguei aqui muito 
abatida, muito abatida mesmo, Eu falava assim, nossa é muita coisa pra uma cabeça só, porque meu marido estava preso, então nossa, era muita coisa mesmo E eu achei que fosse explodir. E eles me deram a maior força me ajudaram bastante mesmo. Então quando eu tenho que vir pra cá eu não penso duas vezes, eu venho eu costumo dizer que aqui é como se fosse minha segunda casa aqui eu fico super a vontade, já conheço bastante gente aqui dentro. Já aconteceu de semana de eu estar aqui de segunda a sexta. Segunda a sexta todo dia. Até um dia eu falei: - Nossa, não agüento mais essa moça!(ri) Teve, a vacina também teve a primeira vez que eu tomei cinco, que a médica mandou, tomei cinco vacina tudo de uma vez. Deu febre, eu sai daqui com os braços tudo duro, ai eu liguei pra cá a noite pra ver se eu podia tomar algum remédio, fui chamar meu médico aqui, aí no ouro dia de manha eu voltei Nossa os braço tudo duro. Porque eu já tomei todas as vacinas que eu tinha que tomar já na primeira vez, que nem a médica foi muito legal comigo, ela falou pra mim e que eu tinha que tomar todas as vacinas, já pra me proteger, né! Que ai o CD4 vai baixando e ai não tem aquele problema de pegar outras doenças, né! Então mesmo que eu tenho pavor de agulha, mas eu não pensei duas vezes, porque eu acho tem que tomar tem que tomar. Porque É melhor agulha do que ficar internada no hospital tanto tempo, eu tenho pavor de hospital, então eu prefiro as agulhas do que ter que me internar depois. Mas eu fico preocupada assim, porque ela falou assim, que quando chegar a duzentos e poucos por ai, eu vou começar a tomar os remédios, né! Eu já tomo um monte de remédio, remédio pra pressão, minha pressão é alta. Então assim eu já fico pensando quando eu começar a tomar esses remédios como vai ser. Então minha preocupação vai disso ai. Então mas como ela fala já vai fazer um ano que eu comecei, meu CD4 ta na casa dos oitocentos ainda, ela falou que não abaixou quase 
nada. Mas ai eu espero demorar mais ou menos uns cinco anos pra começar tomar os remédios porque nossa cada tamanho de comprimido que não é brincadeira.

P: E quando você ficou sabendo como foi?

R: Nossa eu chorei tanto que as vezes eu falo assim... Que eu passei no oftalmo aí na USP, que eu fiz cirurgia aí, né! Ai ele falou que eu tava com problema de lagrima, ai eu falei sabe o que é que eu chorei tanto que já não tem mais lágrima secou. (ri) Ele falou não mas tem sim porque ele também sabe. Porque pra mim tomar o antidepressivo, olha como foi complicado. Pra mim tomar antidepressivo precisou do médico daqui mandar uma carta pra ele, pra pedir autorização que antidepressivo eu poderia tomar porque como eu tava com glaucoma, ele qualquer remédio que eu tomasse ia interferir eu poderia ficar cega em questão de duas semanas ai eu fui pra lá pra poder passar no medico lá no oftalmo aí ele mandou a carta pra de volta cá, aí depois eu comecei a tomar o remédio. Assim, pra mim poder tomar remédio tem que perguntar pra outro medico se pode ai eles mandam carta pra um ai eles responde de novo ah esse pode tomar num pode tomar. Ai nossa as vezes eu me sinto como se fosse uma cobaia daquelas experência, sabe. Mas é um pouco complicado. Mas ai eu volto ao tempo de criança e fico assistindo desenho fico ali encolhidinha assistindo desenho com as criança brinco com as crianças pra poder já esquecer os problemas de adulto. Porque nossa é tanto problema que da vontade de sair correndo. Mas tem que enfrentar, Meu marido fala que nós já enfrentamos tanta coisa, que isso ai é o de menos. Mas afeta varias coisas na vida da gente, Acho que é uma das piores doenças, que a gente tem que enfrentar e um dos maiores problemas que nos tivemos que enfrentar foi o vírus. Porque as outros problemas são mais fáceis, graças a Deus eu tive ajuda do pessoal da Igreja ajuda também. Eu freqüento a 
Igreja Quadrangular, então assim conversei com a pastora, então tem aquela coisa assim, eu me sinto super bem, indo assim pra igreja. E ai quando tem um problema assim quando to fora do rumo mesmo, ai eu converso com ela e ela fala que ah tem que orar. E na verdade orar também ajuda muito. Por incrível que pareça. Igual a gente tava conversando aqui na terça-feira o fato de você ter uma religião de você crer mesmo ajuda bastante. Fora assim as pessoas me ajudaram, mas nosso Deus teve comigo esse tempo todo e se eu não acreditasse tanto nele eu acho que eu não teria agüentado tinha vezes assim dava uma dor tão grande no peito que eu falava nossa é hoje que eu vou morrer. Por muita coisa assim tudo em cima e o plano de ter outro bebe, porque minha filha tem nove anos. Então antes ela pedia um muito um irmão então a gente ficava planejando, quando meu marido saísse da cadeia e a gente arrumasse a nossa vida, eu ia tentar engravidar. Mesmo correndo o risco, porque eu já perdi um bebe. Eu tava com seis meses de gravidez, eu fiquei internada no Hospital das Clínicas quarenta dias porque eu tive pressão alta, diabetes tudo na gravidez. E minha pressão alta em desde quando eu tinha quatorze anos. Então eu falo comigo mesmo eu penso assim, que eu coloquei na minha cabeça assim, o fato de eu não poder engravidar não é por causa do vírus, eu conversei com a ginecologista e ela falou pra mim, se você quiser engravidar já pode começar a tomar o remédio, mas eu já tomo tanto remédio, porque ela falou que tem chance do bebe não ser soropositivo. Então mas eu falo assim, não é nem tanto o neném não ser soropositivo. Mas o problema pra mim acho que não é nem tanto ser soropositivo por causa da gravidez mas é a pressão, porque vai ter que mudar todos os meu remédios de novo, ai eu já sei que vou deixar os médico doido. Eu já falei pra ela se eu chegar a ficar grávida coitada da senhora. Ai já viu, vai que me internar, eu vou ter que ficar 
a gravidez toda internada ah eu falei Eu não to preparada mais pra isso não, de jeito nenhum, por que é mais complicado, porque nem todos os remédios eu posso tomar. Porque acaba que mexe com uma coisa mexe com outra. Ai não, falei não to sossegada. Agora meu marido ta pensando mês que vem, olha só a cabeça, no mês que vem ele vai comprar um jazigo. Que ele tava falando se ele chegar a morrer, como que vai fazer e tal. Então na verdade por mais que a gente pensa que não é uma coisa que não vai morrer disso, por incrível que pareça, sempre acaba passando pela cabeça da gente. Porque no primeiro instante que a gente pensa é -Ah! Eu vou morrer. Mas na verdade a gente vai morrer, mas num pode ser disso. O médico falou pra ele:- Não vai ser isso que vai te matar. Porque o CD4 dele subiu assim em dois meses de duzentos e pouco foi pra quatrocentos e pouco. Subiu bastante. Eu falei pra ele: Nossa fico contente por você, enquanto o seu ta subindo o meu ta abaixando (ri). Ele falou assim pra mim: - Ah, mas não é bem assim. Eu falei assim lógico que é bem assim, porque eu não tomo remédio. Então só to na base da alimentação. Ah, não pode comer gordura, mas eu gosto daqueles bife contra-filé cheio de gordura em volta. Não pode comer, bom, feijoada, feijoada eu gosto por causa daquelas partes do porco. Então fica complicado né. Não pode comer isso mas, eu falo pra eles assim, mas são as coisas que eu mais gosto, carne de porco, bisteca, eu não posso mais comer essas coisas. Ah, mas de vez em quando pode, com essa coisa de poder comer de vez em quando. Eu cheguei aqui pesando 69, ai eu passei na nutricionista e voltei pra sessenta e dois. Ai ela falou assim: Mantêm esse peso que é seu peso ideal. De sessenta e dois agora to com sessenta e nove e alguma coisa de novo. Ah, eu não... O médico falou que meu deu compulsividade de comida. Eu tinha que ficar comendo toda hora. Ai ele tava falando assim que eu to em fase de aceitação. Por incrível que 
pareça ainda não consegui aceitar ser soropositiva, então quando eu penso ai da vontade de comer, ai teve que aumentar a dose do remédio, porque ele ai tirar a fome, eu vou comer só o necessário. Porque eu me sinto ansiosa, fico nervosa, aí eu tenho que comer a unha ou comer alguma coisa, tenho que ficar comendo o tempo todo. Aí nisso, que eu comecei a engordar de novo. E aí eu não posso engordar porque vai sobrecarregar o coração, quer dizer, vai dar mais problema. Eu falo pra onde que eu corro, não tem jeito. Não tem jeito mesmo, aí, olha sei lá viu é duro ter... Por incrível que pareça eu não desisto assim, quando eu começo a pensar tanta coisa que eu já passei. Ah, isso daí é o de menos, isso daí. Eu procuro assim ajudar os médicos, pra eles me ajudar né! Eu não escondo nada, converso normal, o que eu to sentindo eu chego e falo, pra poder eles me ajudarem e pra mim continuar (pausa) Então é isso aí, vamos ver como vai ficar de agora pra frente.

P: Obrigada, obrigada por ter participado.

R: De nada.

\section{Mayara 002}

Entrevistadora - P -: Conta para mim como foi para você quando você soube que estava infectada pelo HIV.

Entrevistada - R -: A primeira coisa que eu achei é que ia morrer. (ri). Nossa, achei que ia morrer, eu queria pôr fim a minha vida, né.Eu não queria ... eu não, queria morrer assim da doença, eu queria logo tomar um outro comprimido e morrer $\log 0$.

P: E aí, o que você fez quando ficou sabendo? 
R: Nossa, foi ruim, foi horrível. Primeira coisa que deu... porque eu já tenho a síndrome do pânico, né, aí agravou. Aí eu tive mais medo ainda, tive pavor de tudo, de todos, todo mundo que me olhava na rua eu achava que sabia que eu tinha, que queria me matar mesmo. Nossa, foi horrível. Foi a coisa mais horrível do mundo. E mais, a gente se desespera, você quer... uma maneira de tratar. Então, eu corri para o Emílio Ribas, eu tratava aqui, eu fui para o Emílio Ribas e quando e... eu cheguei lá eu vi que lá não é o mesmo tratamento daqui, né!, é completamente diferente. O médico te atende correndo, e... ele não te dá o diagnóstico direito, diz que mês que vem ele vai te ver de novo, e foi aonde eu larguei lá e vim para cá, de vez. Então agora estou aqui de vez. (ri)

P: E quando você ficou sabendo, você contou para alguém assim... que você soube?

R: Eu contei para um amigo e foi a pior coisa que eu fiz, né!, que eu contei para ele e ele saiu espalhando. Nossa, eu tava numa igreja nessa época, e ele saiu espalhando dentro da igreja. Quando o bispo ficou sabendo já era tarde, ele já tinha espalhado para muita gente, aí o bispo fez ele calar a boca, até inclusive tirou ele daquela igreja, né.

Bom, eu tive que continuar naquela igreja, mas aí depois eu acabei desviando, né, acabei desviando e estou aqui desviada até hoje, tem um ano já. (ri)

P: E como foi assim contar, o que você pensou quando você foi contar para alguém?

$\mathrm{R}$ : Ah, eu pensei que a pessoa fosse, fosse assim guardar para ele e me ajudar em oração. E não foi assim que foi feito. Então foi difícil para mim. Aí eu já passei a não querer confiar em ninguém mais. Tanto que é que minha mãe demorou para 
saber, minha mãe demorou quase um ano para saber, eu não queria contar nem para ela porque achava que ela também ia contar para os outros. Então, é um trauma que você cria que... vou falar, viu? (pequena pausa) Terrível ... (ri)

P: Como foi para você contar para alguém, como se sentiu. Você falou que foi horrível e... e o que mais assim? O que ficou dentro de você, quando você contou?

R: Ah, quando eu contei foi assim... como é que eu vou te explicar? Quando eu contei, que para mim deu tudo errado porque a pessoa saiu falando, eu tive medo de todo mundo ficar sabendo, né ! inclusive os ex parceiros que eu tive e aí eu tive medo deles pegarem e virem me matar. Então, eu não dormia mais. Eu não dormia, eu não comia direito. Sem contar que dá vontade de você pegar e sair matando tudo quanto é homem, né.(ri) Não, porque você pegou de um homem, e no meu caso eu peguei de um homem que eu confiei nele muito. Eu fiquei com esse homem um ano e sete meses, não fazendo exame, porque eu tava só com ele. Eu não tinha outra pessoa. E ele foi a única pessoa que eu fui fiel, entendeu? então, de repente você ser fiel a uma pessoa e depois descobrir que essa pessoa te pegou AIDS, nossa é, é terrível! Dá vontade de você sair matando tudo quanto é homem. Foi o que aconteceu comigo, mas eu me controlei (ri).

P: Você contou para mais alguém, além dessa pessoa e sua mãe?

R: Então, para minha mãe eu demorei um pouco para contar. A primeira pessoa assim que eu contei foi esse amigo. Depois desse amigo eu contei pro namorado, que era a pessoa que tinha me passado, e... só que eu já não estava mais com ele, eu já tinha largado ele e estava namorando outra pessoa. Aí eu tive que contar para essa outra pessoa, ne. Essa outra pessoa foi muito legal comigo, ficou 
comigo. Quis ficar sério mesmo comigo, aí foi morar logo junto comigo. E a gente conseguiu levar uma vida 10 meses juntos, né. A gente conseguiu levar uma vida até legal. E... aí... depois não deu certo mais... depois não deu certo mais e... agora estou aqui, né, eu voltei a namorar a pessoa que me contaminou, porque eu acho que é obrigação dele ficar comigo. Ele me contaminou, tem que ficar comigo até o fim (ri). Pode ser assim...um raciocínio meio quadrado o meu, mas é assim que eupenso. Ele tem que ficar comigo até o fim.

P: E você guarda segredo sobre seu diagnóstico para alguém?

R: Guardo. Guardo, tenho uma vizinha que eu freqüento muito a casa dela, a gente sai junto de final de semana e ela não sabe. Eu não deixo ela saber. Eoutras amigas minhas também assim... amigas de infância, eu também não deixei saber. Porque eu sei que muda. Depois que a pessoa sabe, os amigos da gente sabe, muda o comportamento das pessoas com a gente. Então, eu acho melhor ficar quietinha. A pessoa ... não está transparente para fora, a doença, então, eu acho melhor ficar quietinha sem contar, né. Até porque o tratamento depois muda, completamente, ne!

P: Você morava no bairro que você mora, né?

R: Ahã.

P: Ser HIV positiva, interfere alguma coisa na sua convivência, no bairro em que você mora?

R: Não porque eu não falei para mais ninguém assim de fora. No bairro mesmo quem sabe é minha mãe, meus filhos, que minha mãe contou para meus filhos, meu irmão sabe e... agora quem também sabe é o pai do meu fiho, né. Mas ele também resolveu ficar quieto, não contar para ninguém, que ele diz que não vai ajudar em nada contar pra alguém, né. Então a gente tá ali, superando, procurando 
superar isso e ele me dá assim ... uma força para tomar os remédios, que é horrível tomar os remédios. É uns comprimidos muito grandes, na hora que a gente vai tomar ele volta, e se a gente não toma cuidado volta tudo que você já tomou, né. E... então ele está me ajudando assim bastante. Ele quer saber se o filho vai negativar, né. Aé que hoje é a primeira consulta do nenê e ele está ali também para ver, para saber como vai saber como vai ser o procedimento daqui para frente. E a gente tá junto nessa, mas só na doença (ri), mais nada, né.

P: O pai do teu filho é seu ex namorado?

R: É.

P: Ex companheiro?

R: Ex companheiro.

P: Mas como é que você se sente em relação ás pessoas que moram perto de você?

R: Ah, eu vivo ... eu ... que depois de um tempo que você sabe dessa doença, você acaba se acostumando. Você se acostuma e aí você convive bem. Se as pessoas ao seu redor não sabem, você convive muito bem. E também tem aqui, o SAE, que a gente trata. Aqui a gente reúne, aqui a gente conversa a esse respeito, entre nós não tem preconceito porque todo mundo tem a mesma coisa. Então quer dizer, aqui a gente ... aqui a gente progride, a gente anda para frente. E a gente aprende a não conviver com preconceito aqui. Então da maneira que a gente vive aqui, a gente vive lá fora, mesmo sem contar para as pessoas, né!

P: Você contou para alguém da equipe do PSF, lá onde você mora?

R: É, não queria contar, não, mas eu contei para uma médica , uma médica que eu passava com ela ... médica da família,né! Eu contei pra ela quando eu fiquei 
sabendo eu contei para ela. Ela foi assim ... me ajudando bastante me aconselhando, em relação aos pensamentos que eu tava. Ela foi me aconselhando bastante e depois dela, como a agente de saúde vai me visitar às vezes no mês, né, a agente de saúde também sabe. Eu não queria que soubesse, não, porque a menina ela é minla vizinha (ri). Então ... mas graças a Deus ela é crente também, ela guarda sigilo, não fala para ninguém, né. Então, me sinto bem lá, agora, né, que agora eu já superei bastante, já acabei me, acabei me ... sabendo agora como conviver com isso,né, mas nocomeço foi muito difícil. Muito difícil, você pensa que as pessoas estão te olhando, porque sabem, e não é nada daquilo. As pessoas estão te olhando porque olha mesmo, né, que te quer cumprimentar ou coisa parecida, mas no início foi muito ruim, mas agora está completamente diferente.

P: E quando você contou para o médico do PSF, que você pensou antes de contar? Que você sentiu, que você pensou ...

R: É que antes de eu ... eu já passava com ela porque eu estava sem psicóloga, né, até então não tinha vindo para o SAE ainda e estava sem psicóloga, então ela me servia de psicóloga. Então, todo final de semana, é toda sexta feira eu encontrava com ela. E aí a gente conversava, eu ia pondo para fora tudo que estava dentro, né, e aí justamente foi nessa época que eu fiquei sabendo do resultado. Até porque eu fiz dois exames assim pra poder vir para cá eu fiz dois exames lá, né. E primeiro constou que sim, o segundo também, aí foi que eles me mandaram para cá. Mas no primeiro exame que fiz eu já me apavorei e eu contei para ela, né. Ah, eu contei para ela porque ela esta me ajudando, né! Ela me ajudava a raciocinar, porque eu não tinha direito um raciocínio. Eu só pensava em medo, medo de tudo e de todos. E aí ela me ajudou muito, ela me ajudou bastante. E para ela foi um choque, né porque ela estava 
me acompanhando e no início não era isso que eu tinha, era só síndrome do pânico. De repente ter uma suspeita de HIV, assim, foi terrível. Ela também sofreu muito com isso. A gente sente quando o médico sofre, né (ri). E foi assim ... foi uma coisa assim pra nós duas estar lutando junto, né. Quando eu contei a gente se abraçou, chorou junto, como se fosse assim duas pessoas da família. Então ela me ajudou também bastante, né. (pausa) Pronto pode perguntar.

P: Você quer falar mais alguma coisa, como foi sua trajetória, seus sentimentos?

$\mathrm{R}: \mathrm{Ah}$, não!

P: Como é para você agora conviver com isso com isso ... O que você quer falar?

$\mathrm{R}$ : Ah, conviver com isso é assim ... é uma coisa que eu sei que não tem mais volta. Eu vou conviver com essa doença, vou precisar tomar remédio, até inclusive agora estou tomando remédio só não sei se vou continuar tomando. E é aquele negócio que o médico já falou, começou a tomar o remédio e não pára mais. Quer dizer, para você sobreviver você tem que viver tomando remédio, quer dizer, a sua liberdade acabou, não é tudo mais que você pode fazer, você tem que tomar cuidado mais com a sua saúde, tem que ter mais cautela em tudo, né, que nem, eu gosto de ir para barzinho, eu gosto de beber a minha cerveja, entendeu, e isso já não vai ser possível. Se bem que eu vou te falar com sinceridade, eu gosto de tomar minha cerveja de final de semana, eu tomo remédio, porque não pode ficar sem tomar o remédio. Eu tomo o remédio e depois de duas horas eu já sei que posso beber de novo, aí começo a beber. Então, quer dizer, hoje em dia eu to levando a minha vida, né, até porque eu já acostumei com isso. Acho que tudo vai de um costume, a gente 
tem que acabar se acostumando porque a gente vai conviver com aquilo, né.E é isso ... só ... (ri)

P: Mais alguma coisa?

R: Não. Não, até porque já passou tudo ... toda aquela mágoa, aquele rancor que eu tinha, que no começo você tem ... você fica até de mal com o mundo. Você pergunta para Deus por que você, o que que você fez, né?, que nem eu mesma, tava numa igreja, então tinha tudo para não ter pegado. E de repente eu pego, eu falei para que eu peguei isso?, Deus, o que que eu fiz?-, você acaba ... se revolta. Só que também se revoltar não vai adiantar nada, você tem que acabar se acostumando mesmo com o problema, e ver que por aí tem gente que tem problema pior que você. Apesar de que, muitas pessoas tem um problema pior, só que não é uma doença discriminada. E essa doença é muito discriminada. É uma doença que causa pânico quando a pessoa fica sabendo que tem. Tanto a pessoa que é portador, como a pessoa que é seu amigo ou coisa parecida, todo mundo se afasta, acha que pega assim, sem ... com qualquer tipo de contato. E é por isso que muda muito o convívio da gente com outras pessoas. Por isso que a gente não fala na doença. Por isso que a gente procura ficar ali com essa doença mesmo só para a gente. E assim vai. Bom, eu penso assim, não sei os outros (ri).

P: E seu relacionamento atual, como se sente?, você falou que ele tem obrigação de ficar com você ...

R: É...

P: Mas como você sente?

R: Não, até porque eu gosto dele. Eu gosto dele já há muitos anos. Quando eu conheci ele eu era casada, com meu primeiro marido, com o marido que e casei, né, e 
a gente se conheceu e foi assim meio conturbado porque eu era casada e ele não era. E na época, eu não lembro direito, mas meu marido parece que descobriu qualquer coisa. Meu marido foi atrás dele para bater, e eu sei até que ele teve que pedir transferência do serviço que ele trabalhava, para não me ver mais. E aí eu não vi mais ele, a gente ficou 12 anos sem se ver. E quando a gente se viu eu já estava viúva. Aí a gente começou a namorar para valer. E nesse começar a namorar para valer foi aonde aconteceu a minha contaminação. Comoeu estava só com ele eu não fiz exame, porque até então, desde 2000 que eu venho fazendo esses exames. Porque eu tive uma tuberculose em 2000, eu era alcoólatra ... e isso você sabe, o alcoólatra não come,né! Então ele está se encaminhando para qualquer tipo de doença. E aí eu tive a tuberculose, então eu fui fazendo os exames de seis em seis meses. Só que quando comecei a namorar esse rapaz eu falei-agora, doutor, para de fazer o exame porque agora estou namorando uma pessoa só. Agora não tem importância, não tem perigo mais -, e foi quando eu descuidei, né. Aí, depois de um ano e 7 meses o doutor resolveu pedir um novo exame. Que tinha me dado uma candidíase, e aí ele pediu para mim o exame. Aí foi onde deu. Só que eu já tinha cansado de namorar ele, eu gostava dele, mas tinha cansado de namorar ele, tinha aparecido um outro mais bonito, então fui namorar o outro mais bonito. E aí foi quando descobri que eu estava doente. Eu fiquei 10 meses separada dele, e depois de dez meses eu voltei. Voltei por gostar e porque ele me passou, né. Mas eu não consigo assim me ver ... me ver assim sozinha, sem ele. Eu acho gente tem que ficar juntos. Nem que for namorando pelo resto da vida, sem morar juntos, sem nada, mas eu acho que a gente tem que ficar juntos. (ri) 
P: Queria te agradecer por tua participação. Obrigada. Espero que isso ajude a outras, que tem o mesmo problema que você.

R: É lógico.

\section{Dalila 003}

Entrevistadora - P -: Conta para mim, por favor, como foi para você quando você soube que estava infectada pelo HIV?

Entrevistada - R -: Para mim foi horrível, né, porque eu estava de 4 meses, aí eu estava naquele postinho de saúde do Butantã, acho que é Centro Escola do Butantã. Aí estava em greve lá, o médico ligou no celular da minha irmã, que eu não tinha telefone ainda na época, aí pediu para mim ir lá urgente. Estava eu e meu marido, ficamos desempregados, nós dois, aí ele falou para mim-olha, só falta ser o que eu estou pensando -, falei - não, não tem como -. Aí a gente chegou lá, o médico não deixou ele entrar, o médico estava me esperando, não deixou ele entrar na sala, eu entrei e ele falou - olha, você está com HIV ...-, que eu já tinha feito exame lá e... você está com HIV e você vai ter que tirar seu filho, porque senão o filho ou filha vai ser infectado e não vai ser uma criança saudável, tudo . Eu sai de lá em desespero, né. Aí ele me encaminhou, falou - olha, eu vou te encaminhar para cá, para o SAE Butantã e lá você vê o que é melhor para você -. Eu vim para cá, fiz o tratamento todinho aqui, tomei remédio a gravidez toda. Minha filha antes dela nascer eu fiquei 21 dias internada, que eu tive préeclampsia, que eu engordei 33 quilos. Então, fiz o tratamento todo aqui. Tomei coquetel, não senti nada a gravidez toda. Aí ela nasceu, era para ela ter nascido no dia 16 de novembro, ela nasceu dia 5 porque eles anteciparam o parto, né. Depois ela tomou aquele xaropinho, que é para 
os anticorpos, e hoje ela é uma criança saudável, assim, ela já negativou, mas ... e eu levo a minha vida normal. Nem lembo que existe ás vezes. Dou força para outras pessoas, não é? E assim, eu tenho um marido do meu lado que é excelente, né. No dia que eu descobri eu falei - olha, você tem todo o direito de levar sua vida, não querer mais ficar comigo, sabe ...-, e ele falou - não, eu vou estar do seu lado para tudo -, então isso que me dá mais força, todos os dias, é ele. E é isso. Queria fazer mais alguma pergunta?

P: Quando você soube, assim que você soube, você contou para alguém?

R: Assim, de momento só ele, meu esposo. E ele queria fazer um pacto comigo que ninguém mais podia saber disso. Só nós dois. E depois eu falei para uma amiga minha. Ela me aceitou super bem, né, porque ela tem conhecimento. Hoje a gente é muito amiga, ficou mais amiga ainda. E eu não falei paraele que eu tinha falado para essa minha amiga. Depois, quando eu não consegui esconder as coisas dele eu acabei falando para ele, mas ele aceitou numa boa. A minha irmã sabe também, também nada contra. A minha cunhada, que é a esposa do meu irmão. Só essas pessoas.

Ele acabou falando para o gerente dele, que eles são muito amigos. E ele nossa, eu admiro muito a ela, porque nem parece, né -. São as pessoas que estão sempre do meu lado, nunca se afastaram, não tem preconceito de nada.

P: Para quem você contou primeiro?

R: Foi para meu esposo ...

P: E o que você pensou antes de contar para ele?

R: Eu não tive nem tempo de pensar. Eu saí da sala já chorando, né. Então, como ele é uma pessoa muito esclarecida, ele já ficou meio assim- o que foi? -, eu já 
falei para ele, logo de imediato já falei tudo. Então, ele ficou meio assim, para ele foi um choque. Então, no momento a gente pensava só na nossa filha, que iria acontecer com ela, como que seria, né. Mas graças a Deus, hoje ela é uma criança saudável, de tudo, né, maravilhosa.

P: Ele é negativo?

R: Ele é negativo. Apesar que faz tempo que ele não faz exame. Ele colheu no ano passado e ele não quer usar preservativo, ele não ... ele fala - não, se tiver que acontecer eu quero que aconteça comigo também -, tanto é que quando ... isso ... o dia que eu recebi o resultado eu vim aqui e fiz outro exame. Antes de eu receber o resultado ele falou para mim - nega, se der positivo, eu te amo tanto que eu vou cortar ... assim ... fazer um corte em mim e em você, e a gente vai pôr um sangue no outro, eu quero ter a mesma coisa que você -. E até hoje a gente nunca usou preservativo. Ele não quer. Então para mim ele é ... não sei ... acho que ... a única pessoa que me faz viver no dia a dia é ele.

P: depois que você ficou sabendo você contou para a sua amiga?

R: Ahã!

P: E o que você pensou antes de decidir contar para ela já que tinha feito um pacto com seu marido de não contar?

$\mathrm{R}$ : Eu contei assim, porque achei que ela deveria saber, assim, pela amizade que a gente tinha. E aí eu ia passar a conhecer quem realmente seriam meus amigos. Se ela fosse minha amiga de verdade, ela não iria se afastar de mim. Mas se ela não fosse ela iria se afastar. Aí depois eu fiquei com aquilo na cabeça, que eu não deveria ter falado, porque ele vai achar ruim pelo pacto que a gente fez, tudo. Mas não, ele aceitou numa boa, falou - não, a cabeça é sua, você sabe para quem você deve falar, 
é um direito seu, de você se abrir, conversar com alguém, então não tenho por que ficar chateado com você ou brigar com você por causa disso -.

A minha família, a minha mãe, a minha sogra, a irmã dele, eu não falo porque são pessoas muito preconceituosas. Não a minha mãe, minha mãe ela é uma pessoa que ela não é esclarecida nesse ponto, né. Já a família do meu mairdo é, só que eu tenho muito medo de falar, e que nem ele falou para mim- você não tem por que falar, eles vão se afastar de você, são pessoas muito preconceituosas, então não tem por que você falar -.

P: Então você guarda segredo do seu diagnóstico para a família dele?

R: É.

P: E para a sua?

R: E para a minha. Tanto é que quando a minha filha nasceu foi muito difícil para a gente, nós dois, lá dentro do hospital estar escondendo isso, né, porque vinham as enfermeiras, traziam o remédio para ela, - ah, o que é isso? -, - não, um xaropinho, porque ela está com tosse, ela ingeriu líquido -, então a gente conseguia ... - ah, por que você não amamentou? -, porque eu não amamentei, né, - ah, porque ela teve diabete gestacional, ela tomou muito medicamento entãoo médico achou melhor não amamentar -. Então, teve todas essas perguntas. E para mim eu sofri muito ali, num quarto com outras mães ali amamentando, e você não poder amamentar. O leite vinha em horários e ela ali chorando, com fome, nossa ... para mim foi... eu chorava dia e noite ali dentro. É muito sofrido para uma criança. Eu agradeço muito a Deus e a ela ... se não fosse ela talvez quando eu fosse descobrir isso talvez não tinha mais jeito, né. E assim ... ela é tudo de bom na minha vida, tudo, sabe. Ba trouxe muita felicidade, muita coisa boa, vim descobrir isso a tempo, se não fosse ela, né. Então, 
até hoje, tudo que eu tenho na minha casa, quando minha sogra vai para minha casa, passa o fim de semana, eu tenho que estar escondendo tudo, porque ela mexe nas minhas coisas. Normal, é o jeito dela mesmo. Então, tenho que estar escondendo as coisas. Porque se ela achar ela pergunta, o que foi ... o que ... Quando eu estava tomando coquetel - ah, por que você está tomando esse medicamento? -, eu falava que era para eu emagrecer, para eu não engordar, então tem todas essas perguntas que eu tive que estar passando por isso.

(pausa)

R: Pode fazer as perguntas ... pode perguntar ...

P: Além da sua família e da família dele, você guarda segredo para mais alguém, do diagnóstico?

R: Não ... Assim, tem alguns amigos meus, do meu marido também, que para mim não há necessidade de falar. Não há necessidade, eu tenho a minha vida, ninguém paga minhas contas, então, eu levo minha vida normal.

P: Você já morava no bairro que você mora hoje, quando você soube do diagnóstico?

R: Já, já morava...

P: Ser HIV positiva interfere em alguma coisa na convivência no bairro que você mora?

R: Não, nenhuma. Porque as únicas pessoas que sabem são agentes de saúde. São lá do postinho, só. Mais ninguém. Eu levo minha vida normal, normal, normal, meu dia a dia. Saio com meu marido, tomo cerveja, levo minha vida normal... danço... Eu nem lembro que isso existe, assim, que eu convivo com isso, que tem isso na minha vida. Nunca precisei ficardeprimida, ali chorando. No começo eu 
fiquei, foi muito difícil para mim, porque assim... pensava na minha filha, pensava muito no que ia acontecer, sabe, eu ficava trancada ali chorando dia e noite. Depois eu falei - não, espera aí, eu tenho que acordar para a vida, que não é assim, né -. Então no hospital eu falava para as enfermeiras, para o médico também,- olha, não quero que ninguém saiba -, - não, ninguém vai saber -, então vinham todos os medicamentos ali naqueles horários para mim tomar. Tem horáio de visita e as pessoas ficavam - não, mas você vai tomar tudo isso de medicamento? -, eu tinha que inventar um monte de coisas, viu.

P: E você não conta para as pessoas...

R: Assim, eu tenho vontade de contar para minha cunhada, que ela é uma pessoa muito esclarecida nisso. Só que eu tenho medo da reação dela, que é a irmã dele, eu tenho medo pelo preconceito, são pessoas muito preconceituosas, então eu tenho medo da reação dela, tenho muito medo, dela se afastar de mim, da minha filha, que as duas são muito apegadas, então eu prefiro ficar na minha. Eu sinto vontade de falar, mas ao mesmo tempo eu prefiro não falar.

P: E você contou para a equipe do PSF, para alguém da equipe do seu diagnóstico?

R: Todo mundo sabe aqui, o pessoal todo sabe aqui, nossa, o pessoal me recebeu aqui... desde a primeira vez que eu vim... eu cheguei aqui muito mal, chorando, e o pessoal me recebeu muito bem. Até hoje eles são... a pediatra da minha filha, maravilhosa, todo mundo... o infectologista, todo mundo ... são muito bons

P: Você falou que contou para a agente de saúde. Ela foi a primeira que você contou da equipe do PSF?

R: Foi, foi... 
P: O que você pensou antes de contar para ela?

R: Ah ... eu falei assim ... sabe ... espontâneo ... falei normal, assim ... não tive nem o que pensar. Eu falei para ela, que eu tive problemas depois, eu fiquei muito inchada depois do parto, não voltava ao normal, tudo ... Ela foi na minha casa, falou - olha, eu vou marcar com uma médica, ela é uma clínica muito boa-, aí ela perguntou se eu estava amamentando e aí eu falei tudo para ela. Foi normal, me aceitou numa boa.

P: Teve medo de contar para ela?

R: Eu tive medo. Sei lá ... como ela mora próxima a minha casa também, comentar com mais alguém ali, mas ... até hoje eu não fiquei sabendo.

P: Conta para mim como é para você ter essa doença, o vírus em você? Como é ser portadora do HIV, como você se sente?

R: Olha, eu não sei nem como te explicar, porque como te falei, eu nem lembro que existe isso dentro de mim, né. Ás vezes penso muito... fico pensando ...será que... -, sei que algum dia vou morrer, todo mundo, mas assim, tenho muito medo que aconteça alguma coisa rápido, logo, comigo, pela minha filha ... Então, eu não sinto nada, nada, nada em relação a ter o vírus, não sinto nada.

P: E em relação a sua família?

R: Ah, em relação a minha família, o que eu te falei, eu tenho muito medo de perdê-los, muito medo mesmo. Nem tanto pela minha mãe, nem minha mãe nem a família dele, ninguém, mas ele mesmo .? É a minha família, da minha convivêna do dia a dia são eles.

P: Você tem medo por ele... 
R: Eu tenho medo por ele, porque eles são pessoas muito dependentes, então eu tenho muito medo por ele... (chora)

P: Mais alguma coisa? Fica à vontade ...

R: Não, pode fazer qualquer outra pergunta que eu respondo...

P: Tudo bem?

R: Tudo bem.

P: Ah... você acha que o PSF te ajuda em alguma coisa?

R: Ah, ajuda, apesar de eu ter convênio, mas eu venho mais aqui. Medicamento, tudo é aqui que eu pego. Mesmo que não seja só para o vírus, que eu não estou tomando medicamento, né?. Mas tudo, em tudo aqui... eu pego leite para a minha filha aqui, pego leite... Não que eu precise disso, mas é um direito meu, né. Eles me ajudam muito aqui, né.

P: E lá no posto?

R: Lá eu nunca passei. Eu fui uma vez, nunca mais.

P: Mesmo com a indicação da agente?

R: Não, nunca passei.

P: Tem algum motivo especial?

R: Não, eu gosto daqui, né, aqui já aprendi a conviver com todos, todos aqui aceitam a gente muito bem. E assim, como também tenho convênio eu prefiro não ir lá. Aqui eu acho que é o lugar mais ideal para meu caso, para o caso da minha filha, né. Então prefiro não ir lá. Ela sabe, a agente de saúde sabe que eu não vou lá mesmo porque eu freqüento aqui.

P: Sua filha ela é atendida aqui? 
R: Ela é atendida aqui, desde que ela nasceu, ela tinha uma semana. Ela é atendida aqui, cada três meses ela faz exames e eu também. E qualquer tipo de coisa, mesmo tendo convênio, como tem a pediatra dela aqui, que acompanha ela desde que ela nasceu, então eu tenho mais confiança em trazer ela aqui. A menos que seja um caso de emergência e procure outro lugar, mas se não for eu prefiro vir aqui.

P: Quer falar mais alguma coisa?

R: Tem um outro... você perguntou se eu participava de alguma ONG, né?

P: Ahã.

R: Tem um lugar que eu freqüento, o MAPA, que ele é daqui, onde tem orientadores, tem a psicóloga daqui que vai lá ... E conversa com a gente. Não que seja meu caso, mas tem pessoas que não aceitam isso. Eu vou lá, converso com outras pessoas, falo - olha, você não pode se sentir assim -, eu dou força para outras pessoas que precisam, né. Então, tem esse lugar, que é onde a gente participa. Todo final de ano eles dão um presente para as crianças, um monte de coisas, né. E é isso...

Quer perguntar mais alguma coisa:

P: Não, só se você quer fal ar mais alguma coisa ...

R: Não... Eu cobro muito do meu esposo, eu falo - vai lá, faz um exame -, e ele - ah, deixa, depois eu vou, eu estou bem, né? -. E eu fico muito curiosa, será que iria me sentir muito culpada, que ele tivesse pegado também o vírus,mas é por uma opção dele, ele não quer usar preservativo, de forma alguma. Então, o que eu cobro muito dele, para ele vir logo, porque se está no começo tem como você tratar melhor, e ele não quer vir. Ele fala - não... -, como ele trabalha muito, ele fala - não, o dia que eu tiver um tempo eu vou -, e ele vai me enrolando, ele nunca vem.

P: Como você se sente com isso? 
$\mathrm{R}$ : Eu me sinto um pouco... eu me sinto mal, porque eu quero cuidar dele também, não só de mim, não adianta pensar só em mim, tenho que persar nele também. A gente tem relação sem preservativo, eu tenho que me preocupar com ele também, né. Então é isso... então...

P: Obrigada, agradeço.

R: Nada.

P: Sua participação é muito importante para que melhore a assistência, tanto de você e de outros que virão, né.

R: Ah, com certeza, outros que virão. E não pode se sentir mal, achar que é o fim do mundo, que acabou sua vida ali porque a vida da gente não acaba de uma hora para a outra. Apesar da gente ter isso, você tem que buscar força no dia a dia para você vencer cada vez mais. Porque se você se trancar num quarto, achar que é o fim do mundo, você vai morrer de um dia para o outro, de uma hora para a outra. Então, você tem que levar sua vida normal, sabe, falar, contar para quem você confia, para quem você acha que deve falar e levar sua vida. Eu sou assim, levo minha vida assim, aceite quem quiser, eu sou assim.

Hoje eu paro para pensar, fico pensando, olho para meu esposo e falo, se eu não tivesse ele do meu lado, eu iria viver assim, pela minha filha. Mas se não fosse os dois... eu nem sei o que seria, né. Pela outra minha filha, apesar dela não ter a mãe dela, né, então assim, ela vem aqui comigo. Ela é uma criança muito inteligente, então eu tenho medo dela começar a pegar uma coisinha aqui, outra ali, e fala... porque criança fala, né. Então eu tenho medo, estou até evitando de trazer ela comigo. Ela me faz perguntas, por que ela não passa aqui também, então tem todo esse tipo de coisas que você tem que conversar, falar, explicar. E eu tenho medo de 
falar para ela porque eu tenho certeza ... uma que não há necessidade dela estar sabendo disso, né. Eu acho que ela é muito criança para isso ainda. Algum dia pretendo falar, conversar com ela, falar o que é certo, o que é errado, porque é para a própria prevenção dela também, né.

P: Ahã...

(interrupção na gravação)

R: ... Com a avó, que seria a mãe dela, teve a vida dele ... tem 26 anos, então agora ela voltou e voltou com isso, né. Só que ela já está ... afetou o fígado, um monte de coisas, né. E essa minha amiga ela é nora dela, né, que ela é a esposa desse meu amigo. Aí eu falei, no dia que eu falei para ela, ela falou - nossa... -, o dia que eu falei para essa minha amiga, falou- nossa, não parece que você tem. Por que você não conversa com a S. -, aí ela falou - olha, eu tenho certeza que a minha sogra tem. Eu tenho dúvidas ainda, mas pelo... -, assim como ela tem enfermagem, ela fez enfermagem, ela falou assim - pela convivência que eu tenho com ela, ela toma um monte de medicamento, ela se sente muito mal, ela toma injeções na barriga, acho que para o fígado, não sei -. Então esse dia que eu falei para a mãe do meu amigo, aí ela se abriu comigo, falou - olha, eu não quero que você fale para a minha nora nem para meu filho, mas eu também tenho -, aí eu falei para ela - por que você não fala para eles?, quem sabe se você não vai se sentir melhor, eles vão te ajudar, porque assim ... você tem seu trabalho, mas você se isola de tudo. Chega o final de semana você se tranca no seu quarto, você não quer saber de ninguém, ninguém pode conversar com você, você vive mal humorada por isso -, e fui conversando com ela, né. Aí ela pegou e falou para a nora dela, primeiro falou com a nora dela. Depois a nora dela conversou com o filho dela. E hoje eles estão super bem os três assim, 
sabe, ele pega ela, apesar dele ser muito revoltado com ela por ela ter abandonado, né, abandonado ele. Ele pega ela, ela faz tratamento no Emílio Ribas, leva ela para passar no médico, ela é uma pessoa que está muito avançada já. Por mais que ela esteja tomando um monte de medicamentos não está mais batendo, né, não está dando mais. Então, ela vira para mim e fala- nossa, queria ser que nem você, que tem muita força, coragem -, eu falo para ela - se desde o começo... -, e segundo ela, ela pegou do namorado dela, que ele usava drogas injetáveis, né. Eu já no meu caso não sei, não sei de quem. No meu primeiro... eu fiquei casada 10 anos no meu primeiro casamento. Aí depois de três anos ... aí depois eu separei, e depois de três anos que eu vim conhecer meu atual marido, né, e ele é negativo, então, aqui o pessoal fala - ah, por que você não procura o seu ex marido, vê se ele tem, para poder ele se tratar, vai que ele não descobriu ainda -. Só que meu marido não deixa, ele fala - não, não quero que você se exponha a esse tipo de coisa -, então eu não sei de quem eu peguei. Não sei mesmo. Ás vezes eu fico perguntando. Nesse intervalo de três anos que eu fiquei sozinha, eu tive outros relacionamentos. Foi pouco, acho que dois, então eu fico - será que foi do meu ex marido?, será que foi de um desses outros dois? -, então eu fico o tempo todo me perguntando. É uma coisa que eu me sinto mal com isso, porque - quem será?, quem foi que fez isso comigo?-, porque se a pessoa não sabia, tudo bem. Mas se a pessoa sabia ela agiu de uma má fé comigo, né?

\section{Selena 004}

Entrevistadora - P -: Conta para mim, por favor, como foi para você quando você soube que estava infectada com HIV? 
Entrevistada - R - : Quando eu soube que estava infectada ... fiquei desesperada, fiquei depressiva. Aí... Eu fiquei muito triste de saber, né, pensava que ia morrer, tudo, porque eu não sabia como que era. Aí o pessoal do posto me encaminhou para a psicóloga, psiquiatra. Aí ela foi explicando. Aí eu fui tendo entendimento, né. Mas mesmo assim eu estou triste ainda.

P: Como que aconteceu isso?

R: Como que aconteceu? Que meu marido ele ficou internado. Ele teve uma convulsão, aí ele ficou internado. Aí ele fez vários exames lá na USP e o médico deu o diagnóstico para ele e pediu para eu fazer exame. Foi quando eu fiz exame e descobri também.

P: Quando você soube, você contou para alguém assim que soube?

R: Eu não, mas meu marido assim ele começou a falar para as pessoas, que ele entrou em depressão, e todo mundo queria visitar ele quando estava no hospital. E aí ele falou que tinha, então lá todo mundo sabe, que ele falou.

Mas eu não comento, não. Tem gente que não sabe, porque eu não falo. Mas dele o pessoal sabe. Mas agora de mim ... o pessoal sabe dele, mas de mim não, né.

P: Para quem você contou primeiro?

R: Para quem? Ah, contei para a minha mãe primeiro, foi para a minha mãe.

P: E para mais alguém depois?

R: Não. Eu não falei para ninguém, não, só para a minha mãe.

P: Como foi para você contar pela primeira vez para alguém, para a sua mãe, que estava infectada? Conta para mim como foi.

R: Como foi? Ah ... eu cheguei nela, chamei ela ... eu não queria falar, né, aí a minha sogra pediu para eu falar, chamou ela lá em casa e eu falei. Falei que estava 
com o vírus HIV, que meu marido estava e que eu tinha pegado também. Aí ela ... sei lá, acho que ela não ficou triste na hora, para não me deixar mais triste, né. Minha mãe supera mais do que eu.

(pausa, silêncio)

P: Que mais ... o que você sentiu antes de contar?

R: O que eu senti?

P: O que você pensou ...

R: Ah ... eu me senti mal, só chorava, só chorava. Fiquei com uma depressão, chorava, chorava ... e acabei falando, né. Depois eu fiquei normal, não tinha jeito mais, contar mesmo e enfrentar a vida. Meu marido ainda estava doene, tinha que ajudar ele, aí fui levantando, levantando, foi quando contei e toquei a vida para frente.

P: Você não contou para mais ninguém depois que contou para a sua mãe?

R: Não, só contei para a minha mãe. Aí depois, um tempo atrás, eu tinha uma colega que trabalhei duas vezes com ela, aí ela descobriu, porque o rapaz que é daqui é amigo dela e ele falou para ela. Aí ela perguntou para mim. Aí quando me perguntam eu sou obrigada a falar, eu não consigo mentir. Aí ela perguntou e eu falei para ela, uma colega minha. Mas eu não fico falando para as pessoas, só se a pessoa me prensa assim na parede e pergunta para mim. E só se for colega ... bem colega mesmo, senão eu não falo.

P: E alguma coisa mudou para alguém que você contou, o relacionamento?

R: Assim, ela falou que a nossa amizade não ia mudar, mas eu acho que mudou, porque ela não foi mais em casa. Ela passa assim ... ela mora a uns 10 minutos da minha casa. Ela não foi lá, ela não liga para perguntar se eu estou bem, 
não vai em casa. Eu acho que mudou, sim. Eu acho que mudou. Eu acho que muda, sim, quando você conta, acho que a pessoa afasta, eu acho.

Eu tenho uma amiga que é muito amiga minha, a gente sai para procurar serviço, tudo, trabalhei com ela já duas vezes. Ela mora na rua de cima da minha casa, mas eu não falo. Tem pessoas que falam - ah, você devia contar para ela -, mas eu não falo. Eu não confio de falar mais, para ninguém, sabe, então eu não falo mais. Às vezes uma amiga descobre e pergunta, mas aí como ela não descobriu, eu não falo.

P: Essa desconfiança de contar surgiu em algum momento, foi por alguma coisa que aconteceu?

R: Como assim?

P: Você falou que não confia mais em contar para as pessoas ...

R: Então, não confio porque eu contei para essa a minha colega e ela afastou de mim. Então, eu prefiro mais não contar.

P: Foi a partir da experiência com essa sua amiga que você resolveu não contar ...

R: É, prefiro não contar para ninguém. Tem pessoas que sabem que me tratam normal, mas tem amigas que eu não confio em contar, não. Eu não falo nada. Por mim ninguém sabia, nem a minha família, mas a minha mãe também falou com a minha família. E a família também não liga para perguntar se eu estou bem, como eu estou. Então eu falo para a minha mãe - que adiantou você ter falado? -, a pessoa só vai ter pena de mim, então era melhor não ter falado.

P: E sua mãe contou para a sua família... 
R: Minha mãe contou. Contou para as minhas tias, para algumas tias minhas, não é toda minha família que sabe. E essa tia minha também não falou, não espalhou muito. Minha mãe que contou, ficaram todo mundo apavorado, mas ninguém foi lá em casa. Nunca foram, faz 10 anos que eu moro com meu marido, ninguém foi lá em casa. Então acho que não devia ter contado, porque eles não ajudam, só vai ter pena mesmo. A única pessoa que liga para mim para perguntar se eu estou bem é minha mãe e a minha tia, a outra tia, a solteira. Porque as outras também não perguntam ...

P: Você guarda segredo do seu diagnóstico para alguém?

R: Ah, eu guardo. Para a minha amiga mesmo, ela nã sabe, né. Ela podia até tratar eu bem, com .?., só que eu não confio mais. Então, ela não sabe.

Quem mais ... a minha colega... antes de eu casar, tudo, não sabe também, eu não conto. Então, eu prefiro não contar. Tem muita gente também que não sabe. Prefiro ficar em segredo, né.

P: E seus filhos?

R: Meus filhos não são portadores.

P: Eles sabem?

R: Não, eu não contei ainda. Mas assim, eles tem uma imaginação assim, que eu trago eles aqui no posto, eles pegam remédio para o pai deles, sabe, ele sabe que a gaveta está cheia de remédios. Ele sabe que o pai dele tem problema. Mas assim, eu não cheguei e falei que era HIV, que eu não sei se ele vai entender. O menino tem 7 anos, a menina tem 9. então, eu não sei ... acho que não está na hora ainda para falar. Eles sabem que a gente faz um tratamento, que faz exames, toma remédio. Isso ele sabe, eu falo - vamos no médico -, que a gente fala com o pessoal que não vai entender nada. A criança não tem muita noção do que é. Eu prefiro não falar, por 
enquanto não. Eu vou chegar e vou esclarecer, mas por enquanto, eles são muito crianças ainda, para entender.

P: Ahã. Você já morava no bairro que você mora hoje, quando você ficou sabendo, né?

R: Já.

P: Ser HIV positiva interfere em alguma coisa, a sua convivência no barro?

R: Não ... acho que ... acho que não. Não interfere em nada, não. .?., normal ... Sabe, eu nem ligo mais, porque no começo eu sofri muito preconceito. Hoje eu nem ligo mais, se a pessoa tiver preconceito ou não tiver. Se perguntar para mim você tem HIV? -, eu falo - tenho, e daí? -, não estou nem preocupada com o que os outros pensam, sabe, tanto que eu sofri... Para mim se os outros quiserem falar comigo pelo que tenho ou pelo que não tenho, eu nem ligo. Mas eu não gosto de ficar falando. Só se a pessoa chegar e ficar perguntando, mas eu chegar e contar, não.

P: Você contou para alguém da equipe do PSF, lá do posto, sobre seu diagnóstico?

R: Não, no posto lá ninguém sabe. Não contei.

P: Que você pensou assim, para tomar a decisão de não contar?

R: Ah ... eu pensei assim ... que lá ... eu não passo muito lá. Eu passo mais aqui, no caso. Então eu pensei assim, se eu contar lá ... sei lá ... tenho medo até de alguém da V.Dalva ficar sabendo, que eu conheço muito o pessoal, né, da Vila Dalva, aí eu pensei - se eu passo lá, por que o pessoal aqui precisa saber? -, e eu não passo lá mesmo. Minhas crianças quando ficam doentes eu levo na USP ou no Pronto Socorro, só é a consulta que eles passam lá. Então, meu marido também não passa lá, então eu prefiro que ninguém saiba lá ... o pessoal de lá. 
P: E o agente comunitário?, você não contou, não sabe, né?

R: Não. Também não contei. Que a agente comunitária ela mora lá na mesma rua que a minha, eu pensei - não, é melhor também eu não contar -, eu não sei também como vai ser a reação dela. Apesar que ela é muito legal, até arrumou uma fisioterapia para meu marido, mas eu não confio de contar, sabe? Não confio para contar para ninguém. Eu acho que se eu contar a pessoa vai ter aquele preconceito, de longe mas vai ter. Vai tratar eu diferente, sabe, então eu prefiro não contar. Que o pessoal lá já que sabe, sabe já há muito tempo, então o pessoal já acostumou com a gente, já acostumou com o jeito da gente, não tem .? Que eu moro no quintal da família dele, então nãotem mais o que ... pessoal assim ... eu não sei como pode ser a reação dela, se ela pode contar para alguém. Então eu acho melhor não falar.

P: Então ela mora perto, e isso influencia não contar?

R: Não. Eu prefiro não contar. Prefiro não contar. Ela mora lá perto de casa ... eu prefiro não contar mesmo. Se alguém souber ... apesar que quase toda a rua sabe, né, não sei como essas pessoas sabem, mas eu prefiro não contar.

P: Mais alguma coisa que você queira falar, de como se sente... de como é para você ...

R: Ah ... antes eu me sentia muito mal de saber, né. Agora eu me sinto normal, me sinto bem agora, porque tem a minha mãe, tem a minha tia, e meus filhos não tem nada. Quando descobri pedi muito a Deus para livrar meus filhos, que é muito doloroso em criança, né. Eles podiam ter que tomar remédio, eles podiam estar, mas não estão. Aí eu fiquei mais contente de saber que meus filhos não tinham. Agora é tocar a vida para frente, não vai voltar atrás, é tocar a vida para frente, cuidar dos meus filhos, que eles precisam de mim. 
Mas no começo eu só queria morrer, morrer. Ficava chorando, meus filhos eram pequenos. Depois fui pegando força, fui melhorando. Agora está aí, né, tem que tomar os remédios ... e tocar a vida para frente, não vai voltar para trás mesmo, né.

P: Como está o relacionamento com seu marido?

R: Como está o relacionamento? Ah ... não é aquelas coisas, né, mas é ... normal ... Ele tem muito problema, mas ele é um bom marido. Normal, né.

(silêncio)

Quer perguntar mais alguma coisa?

P: Quer falar mais alguma coisa?

R: Não.

P: Alguma coisa que te entristece muito?

R: (silêncio) ... Ah ... não ... eu já superei, né, eu tomo os remédios. Mas estou bem, não posso reclamar, que eu nunca fiquei doente, nunca me internei ... Meu marido já foi internado três vezes, quase morreu. Então não posso reclamar, porque tem pessoas que estão pior do que eu, estão numa situação pior do que eu, tem os filhos infectados, eu dou graças a Deus que meus filhos não tem nada ... Coisa ... como se diz ... coisa do destino mesmo, né. O que a gente tem que passar ninguém passa pela gente, então, tenho que ficar com meu problema e tocar a vida para frente.

Mas é triste, porque é difícil, porque eu fui criada ... eu fui criada com muito rigor, eu não podia sair. Eu não curti nada, não curti salão. Depois eu engravidei, arrumei dois filhos e eu não aproveitei nada da minha vida, né. Não que eu não possa aproveitar, mas do jeito que eu fui criada, eu não tenho jeito ... eu não tenho jeito, sabe, mais, para aproveitar a vida. Então é desse jeito mesmo. De casa para o trabalho e do trabalho para casa. Quando aparece algum serviço, quando eu tenho um 
dinheirinho, eu saio com meus filhos. Mas curtir assim, eu sozinha assim, sair com colegas, não, eu nunca tive isso. Nunca tive ... porque eu fui criada com meu padrasto. Meu padrasto não deixava eu sair, então, me acostumei, sabe, a viver assim. Então, só saio com meus filhos e meu marido, só com eles. É isso.

P: Você ainda freqüenta a Assembléia?

R: Freqüento. Freqüento, mas lá também eu não falei para ninguém. Porque uma vez eu falei com o pastor de uma igreja e todo mundo da igreja ficou sabendo. Então, eu achava que todo mundo estava olhando diferente para mim. Então, prefiro não contar para ninguém da igreja também. Eu vou, como uma pessoa normal, mas não falo dos meus problemas também, não. Faço minhas orações lá e vou embora.

P: É isso ...

R: Bom ...

P: Queria te agradecer a participação. Vai ser muito importante, acredito, para melhorar e fazer um trabalho mais... para tirar o preconceito das pessoas, né ... que é importante para melhorar.

R: É ...

P: Queria te agradecer. Muito obrigada mesmo por participar, e logo que ficar pronta eu entro em contato com você. A gente conversa. Se tiver dúvida de alguma coisa você pode me ligar. Agradeço muito, de coração tua participação. É muito importante mesmo, porque se não forem vocês falando da sua experiência, não tem como fazer este trabalho.

R: É, a gente mesmo, né... 
P: Então, se vocês não disserem, eu não tenho como fazer a pesquisa. Então agradeço muito, obrigada mesmo pela disponibilidade de vir aqui, conversado comigo ...

R: Ta.

\section{Jade 005}

Entrevistadora - P -: Conta para mim, por favor, como foi quando você soube que estava infectada pelo HIV?

Entrevistada - R - : Fundo do poço, terrível.

P: O que você pensou?

R: Nunca em morrer, sempre lutar para criar minha filha. Foi muito ruim, muito, como está sendo até hoje. Mas eu sou uma pessoa muito determinada, muito batalhadora. Eu preciso e quero muito viver para ficar do lado dela, e do bebezinho.

P: Como foi que você ficou sabendo?

$\mathrm{R}$ : Eu contrai do meu marido, eu já estava separada dele na época. Ele sofreu um acidente, ficou internado 13 dias na UTI. Ele teve traumatismo craniano. E nos exames que foram feitos dentro do hospital, que eu acredito que nem ele sabia, foi detectado. Aí após o falecimento dele as irmãs me chamaram e me contaram. Isso aconteceu em 93, eu só fui ter coragem de fazer o exame em 97.Isso.

P: Quando você ficou sabendo, você contou para alguém?

R: Não. Só elas mesmo, minhas cunhadas que sabiam, ninguém mais.

P: Para quem foi que você contou primeiro?

R: Minha filha, a única que contei foi para minha filha, a mais velha. 
P: Como foi para você contar pela primeira vez a alguém, que você estava infectada? Para sua filha nocaso.

R: Uma situação muito ruim... para mim ... talvez eu me senti mais à vontade por ser ela. Eu pedia para que ela me entendesse, que eu não contrai isso na rua, fazendo coisas erradas. Deixei ela ciente que foi do pai, e que eu não estava aqui para julgar ele nem ninguém. Que eu só queria me cuidar. E foi onde eu procurei aqui e comecei a me tratar. Que até então eu guardava só para mim, não queria saber, omiti para todo mundo, escondendo até de mim mesma, para não pensar e ficar pior do que eu já estava. E a minha vida desde que eu fiquei sozinha foi com ela, com mais ninguém. Só.

P: O que você pensou antes de contar para a sua filha?

R: Pensei muito, porque ela já estava grávida, pensei muito se eu devia ou não. Só que eu me encontrei numa situação que eu precisava de um apoio, precisava de uma pessoa que estivesse à par do que estava acontecendo comigo, e foi ela a primeira pessoa que veio na minha cabeça. A gente conversou muito e lógico que tudo que ela sempre foi de bom para mim aumentou ainda mais que ela é muito minha amiga, muito companheira. Tem me ajudado muito. Eu acredito que se não fosse ela, esse bebê que ela(?) me deu agora ... eu não sei se eu estaria aqui de pé, porque eu cheguei aqui com o Dr. Paulo e a Dra. Beatriz muito mal. Minha cabeça estava péssima, só pensando besteira. Entrei em depressão com tudo. Hoje graças a Deus estou bem melhor.

P: Há quanto tempo você contou para a sua filha?

R: Dois meses.

P: Nesse tempo que você guardou segredo, como foi para você? 
R: Procurava não lembrar. Eu procurava acreditar que era uma pessoa normal, que não tinha nada. Tanto que não tive... e que ...

$\mathrm{R}:$ E que tudo isso ... ia passar ...

R: Foi isso. Para mim era muito duro aceitar. Para mim tomar remédio ... ia acontecer um monte de coisas comigo, que as pessoas iam descobrir. Eu ouvia falar uma coisa aqui, outra ali, então para mim eu não queria lembrar que existia essa doença, não queria lembrar que estava infectada.

Errei muito, porque eu me perdi de mim por conta disso, mas eu tenho certeza que Deus é maravilhoso, eu não digo que vou me curar, porque não existe a cura, mas eu vou me tratar e eu vou viver por mais um tempo, se Deus quiser.

P: E você guarda... você só contou para a sua filha?

R: Ahã.

P: E você guarda segredo sobre seu diagnóstico para alguém?

R: Guardo e vou continuar guardando. Para a minha família, colegas de trabalho, amigos, todos.

P: Ninguém mais sabe além da sua filha.

R: Não, as minhas cunhadas, da parte dele, do meu ex marido, só.

P: Suas outras filhas também não sabem?

R: Eu até pretendo contar. Não estou preparada ainda, mas eu pretendo chamar as duas e contar daqui a um tempo. Deixar minha vida ... um pouco mais. A minha cabeça estar um pouco melhor, porque eu tenho certeza que vai ser um baque para elas, muito mais do que foi para a mais velha, que é mais madura, mais cabeça. É outro ritmo, mas eu vou contar. 
P: Você já morava no bairro que você mora hoje quando ficou sabendo, né. Ter o HIV, para você, morando nesse bairro, interfere alguma coisa na sua convivência com as pessoas?

$\mathrm{R}$ : Se as pessoas passarem a saber do diagnóstico com certeza sim. Infelizmente existe um preconceito, uma ignorância muito grande. Tem pessoas que ouço falar ainda, que um aperto de mãos contrai o vírus HIV. Infelizmente. E a gente sabe que não é assim. Mas você é vista com outros olhos. Eu escuto pessoas fazerem comentários, de suspeitas, de outras pessoas, que não tem nem certeza. Comentários maldosos, comentários que me magoam muito. Eu tenho certeza que mesmo não sendo portadora, a minha criação não permite isso. Acho que todos somos iguais, independente de qualquer coisa. Mas a grande maioria não te aceita como um cidadão normal. Existe muito preconceito, você é rotulada, é discriminada em qualquer parte. Infelizmente.

Então, eu estou conseguindo viver bem assim, embora não seja fácil, mas eu prefiro continuar.

P: Sem contar para ninguém.

R: Sem contar para ninguém. Levo a minha vida normal, tudo. Tomo meus remédios, ninguém precisa saber o que eu estou tomando e continuo levando assim.

P: Você contou para alguém da equipe do PSF lá de onde você mora?

R: Não, nem sei quem é essa equipe. Nunca procurei, graças a Deus nunca precisei. Só aqui mesmo que eu me trato.

P: Tem um agente comunitário que passa na sua casa...

R: Não sei, porque eu trabalho o dia todo. Mas tem, sei que tem, porque tem vizinhos lá... eles vão fazer visita quando a pessoa está doente, que não podem ir até 
o posto, eu sei que tem, ouço alar muito bem, mas eu nunca tive contato e espero não precisar, para não ter ninguém lá...

P: E o que você pensou para não contar, assim, não ir na unidade para contar, ou não contar para o agente ...

R: É o que eu te falei! Uma coisa da minha cabeça, uma decisão minha. E que eu sou uma pessoa muito fechada, e foi a forma que eu consegui, tipo umalicerce, para mim continuar vivendo normalmente. Não quero ser apontada como- aquela ali é doente -, entendeu?, eu quero levar a minha vida normal, sem prejudicar ninguém.

Já fiz a opção de não ter outro parceiro, de me dedicar somente a minhas filhas. Porque da mesma forma que eu contrai injustamente, que não merecia, eu acho com ninguém tenho esse direito...

Mas tudo bem, graças a Deus, eu estou bem. Só.

P: E como você se sente com esse segredo, que é grande para você?

R: Olha, eu acho que até poderia ser pior, mas eu consegui administrar isso dentro de mim. Então eu sou uma pessoa muito limpa, muito cuidadosa, com tudo. Eu me cuido, da minha alimentação, da minha saúde, cuido de tudo. Então para mim assim não tem ... acho que pior é você saber que tem a doença, não é você conviver com ela. Então para mim tem sido normal. Eu tento que meus dias sejam normais. Tem dia que estou pior, tem dia que estou melhor. Tem dia que eu acredito que vai chegar a cura, em breve, que não só eu como milhares de pessoas vão se salvar. Mas procuro não pensar o pior. É isso.

$\mathrm{P}: \mathrm{O}$ que te entristece? 
R: Saber que eu vou morrer. Sempre tive muito medo da morte, independente de qualquer coisa, mas saber que eu vou morrer, e em que condições, isso me entristece muito. É o que mais me deixa triste.

P: Por não saber como vai ser isso, quando chegar a hora...

R: Exatamente. O sofrimento da minha filha, meu, das minhas filhas, eu não quero pensar. Eu prefiro não pensar. Entregar nas mãos de Deus, ele sabe o momento certo, ele sabe de que forma conduzir isso, e eu só tenho que aceitar e agradecer cada dia de bom que me aconteceu na vida. Só.

P: Muito obrigada. Agradeço muito ter participado. Espero que esta entrevista e as outras contribuam muito para melhorar isto. Até para fazer campanha, que seja, para as pessoas reverem(?) o preconceito.

R: Assim, o tratamento eu tenho consciência que evoluiu muito, que hoje é um dos melhores tratamentos no Brasil, mas as cabeças das pessoas a gente não pode mudar. Infelizmente é bem assim- aquela ali tem AIDS -, - morreu, será que foi de AIDS? - Eles tem uma ignorância a ponto de não saber que a pessoa não morre de AIDS, ela morre de uma doença oportunista. Como uma pneumonia pode matar uma pessoa de soro negativo, pode matar uma de soro positivo. Mas - essa morreu de AIDS -, - aquela aí saía com todo mundo, aquela ali..., isso que me deixa triste demais, porque ninguém procura estudar, ninguém procura entender, ler antes de julgar.

Eu contraí esse vírus de uma pessoa que eu acreditava ser fiel, ser leal comigo, que foi meu marido, e tenho isso comigo. E como eu tem várias pessoas, é de .?., é de um relacionamento, então, ninguém tem culpa de ter. 
Claro que se pudesse escolher ninguém teria, ainda mais sabendo que é uma doença que não existe cura ainda, mas acontece e as pessoas te discriminam muito. Acho que é a pior parte, porque saber que vai morrer um dia, todos nós vamos, mesmo que tenha medo. Mas eu acho que a discriminação, o preconceito dói muito mais.
P: Obrigada.
R: De nada.
P: Agradeço a disponibilidade.
$\mathrm{R}$ : Eu podendo e eu colaboro.
P: obrigada.

\section{Aysha 006}

Entrevistadora - P -: Conta para mim como foi para você quando soube que estava infectada pelo HIV?

Entrevistada - R - : Ah, foi horrível, eu até tentei me matar... O guardinha que não deixou, não teve jeito. Mas foi horrível, a pior coisa. Se você não tiver fé em Deus, você não vive, não.

P: Como foi que você ficou sabendo?

R: Fui fazer exame normal, de rotina, de sangue, lá no posto São Jorge. Daí cheguei lá, tirei o exame, colhi. Daí com 15 dias veio resultado. Achei estranho, porque vir aqui com 15 dias. Aí eu fui lá e o médico falou, que eu estava com o vírus HIV, aí mandou vir para cá. No mesmo dia eu vim, aí fiz novos exames e constou.

P: Você estava grávida?

R: É, estava grávida do R., de três meses. 
P: E foi no exame da gravidez?

R: Foi no exame da gravidez, o exame de rotina que o médico pede. Aí eu descobri.

P: E você contou para alguém assim... quando ficou sabendo?

R: Só para meu marido, minha mãe, que me deu as costas. Minhas imãs também. Mas eu também não ligo, porque o importante é ter fé em Deus. Foi só para eles, eu não conto por causa da discriminação, a pessoa fica muito discriminada, entendeu? Aí só para a minha família mesmo.

P: E qual foi a primeira pessoa que você contou?

R: Para meu marido. Ele veio comigo. Depois eu contei para a minha mãe Aí eu fui, falei com a minha irmã e tal, para ver se eu tinha um apóio. Aí eu fui e me deram as costas.

P: O que você pensou antes de contar para alguém? Para a primeira pessoa que você contou.

R: Tipo assim, ele não porque foi ele que transmitiu para mim. Mas eu ficava pensando - eu vou contar para a minha mãe, o que ela vai fazer? Será que ela vai me dar apóio, será que ela vai me dar as costas? -, então já me preparei para aquilo, porque dependendo da situação dela, do que ela ia fazer, eu já estava preparada. E aí, o que ela fez?, ela me deu as costas. Ela, minhas irmãs... Então só tenho apoio do meu filho e do meu marido.

P: Eles sabem? Seus filhos?

$\mathrm{R}: \mathrm{Ah}$ ?

P: Seus filhos sabem? 
R: Não. Só o mais velho. Os outros não. Eu não tenho coragem de contar, porque é criança, você conta e sai espalhando e pronto. Aí onde eu moro a discriminação muito grande. Se olhar para as pessoas você vê, o jeito que elas falam das pessoas que tem. Porque tem mais pessoas lá onde eu moro que tem o vírus. $\mathrm{O}$ jeito que meus vizinhos falam das pessoas que tem... assim... é muito chato.

P: Te entristece?

R: Bastante. Bastante porque tipo assim, tudo bem que essa doença é transmissível, mas eu acho que ... acho não, tenho certeza que não pega num abraço, não pega num beijo. Então as pessoas tinham que deixar de ser um pouco mais ignorantes, e procurar saber como é que pega essa doença, como é transmitida e sei lá ... dar mais carinho, mais atenção para as pesscas que tem, porque a pessoa que tem, ela necessita disso, de carinho, afeto, sentar, conversar, chorar, desabafar, entendeu? E fé em Deus... estou vivendo.

P: As pessoas da sua igreja sabem?

R: Sabem.

P: Como foi contar para eles?

R: Eu tipo assim, eu quando fui para a igreja eu falei comigo mesma, que se ele existisse, ele ia me provar. Que eu já vi tantas curas assim, de pessoas que são infectadas pelo vírus HIV, de câncer. Falei - bom, se Deus pode curar eles, então ele também pode me curar. Se ele existir, ele vai me curar -. Tanto é que eu não tomo remédio. E eu peguei, falei com o pastor, sentei, expliquei, e é isso.

P: Ele te apóia?

R: Apóia. Às vezes assim...:.quando falta um arroz, que é difícil você criar 6 filhos, ás vezes se falta um arroz, um feijão, se eu for lá no pastor ele me arruma, 
entendeu? O ruim é a discriminação, a pessoa olhar para você e falar-aidética -. Não é assim, que eu acho que o vírus é o que?, a mesma coisa que uma pressão alta, que você tem que tomar remédio, controlar. E eles não vêm assim, a ignorância é muita. Mas... a vida da gente é com fé em Deus.

P: Você falou que quem sabe é sua família, seu marido, seu filho e o pessoal da igreja?

R: Isso.

P: Você contou para mais alguém?

R: Não.

P: Não...

R: Para você, agora. (ri). Porque tipo assim, eu não sei qual vai ser a reação das pessoas, entendeu? A pessoa está te tratando bem até o momento que ela não sabe. Quando ela sabe com certeza vai te virar as costas. Ainda mais onde eu moro. Então, eu prefiro ficar assim. Ás vezes eu até invento que tenho leucemia, quando ficam enchendo muito o saco para saber, mas já por esse motivo, pela ignorância, entendeu? Eu fico quieta, é melhor.

P: Você guarda segredo, então, sobre seu diagnóstico para algumas pessoas.

R: Isso. Para aquelas pessoas que são ignorantes, entendeu, porque para mim é ignorância Hoje em dia, se você fizer o tratamento direitinho, você não vai morrer disso, ela não vai te matar. Você pode morrer de qualquer outra coisa. De gripe, de dengue(?), de qualquer uma coisa, mas dela não. E as pessoas já não acham assim,-ah, é aidética - (fala com ar de desprezo)... já começam a falar, sabe. E sinceramente o nome que eu tenho mais raiva é ser chamada de aidética. Eu fico muito brava.

P: Você tem nome, né? 
R: Aí eu fico muito brava. Muito brava mesmo. Só o nome que... tudo bem, você tem, mas não precisa ficar lembrando que... não precisa ficar te chamando de... entendeu?, então é onde chateia. Acho que o pior nome que colocaram nela foi esse, chamar as pessoas de aidéticas. Não tinha um nome melhor, não? Eu penso assim, mas... vou levando.

P: E assim, todos seus filhos são do mesmo pai?

R: Não. O mais velho foi do primeiro casamento, aí o D. foi do segundo e os outros são todos do mesmo pai. Só dois que não. Mas nenhum deles tem, já fiz exame... Inclusive o R. que está aí, ele fez exame e não deu nada, está negativado. Pelo menos isso, porque se eles tivessem eu não ia... não sei, não, eu não ia estar com essa força toda que você está vendo aqui, não. Eu peguei, vou fazer o que? Eu tenho que me conformar, são coisas da vida, tenho que me conformar. Mas meus filhos ter, eu não ia agüentar, não. Porque ele não pediu para vir, graças a Deus ele está aí, saudável, lindo, sapeca, bagunça muito, mas... Eu acho que você tem que ter fé em Deus, se você não tiver Deus no coração, você não tem nada.

P: E você falou do seu marido, como que é vocês dois, já que os dois são portadores?

R: A gente vive a vida normal. Um ajudando o outro... às vezes ele fica meio... sabe? Aí eu sento, converso, é um em parceria com o outro, entendeu? A gente vai vivendo, vamos levando a vida.

P: E você já morava no bairro que você mora hoje...

R: Já.

P: Quando você ficou sabendo, você acha que ser HIV positivo interfere alguma coisa, na convivência do bairro quevocê mora? 


\section{$\mathrm{R}$ : Se eles ficar sabendo? \\ P: Sim.}

R: Se a pessoa ficar sabendo, sim. É que nem eu falei para você, é muita pessoa ignorante. Eles dão as costas mesmo e não estão nem aí. Entendeu? Até minha irmã, minha irmã mesmo chegou e falou assim para mim:- ah!, vou pegar as crianças e vou levar elas para fazer exame-. Aquilo me doeu, porque tipo assim, eles já fizeram exame, mas não tem. E ela falando que ia fazer exame, por que? Achando que eu podia me cortar e passar para eles? Eu sou a mãe, né. Foi o que eu falei para ela - eu sou a mãe - se eu tenho, vou fazer o que? Mas eles não tem, e eles não são obrigados a ter.

E as pessoas do bairro, com certeza, são todas ignorantes. Iam virar as costas. Por isso que falo da leucemia, eu já sou amarela mesmo.. (ri). Apesar que eu me sinto mal. Se eu falar a verdade, o jeito da pessoa te olhar é diferente. Então, tipo assim, ele julga você, mas ele não quer te ajudar. E eu acho que não é assim, que atire a primeira pedra .?. Você sabe seu dia de hoje, mas o de amanhã você não vai saber. Então, no bairro é assim, são todos ignorantes. Não procuram saber, não procuram ir no médico, perguntar para o médico como é que pega, não. Eles julgam você, que você é safada, que você saiu com fulano, saiu com sicrano, e é bem feito. Ainda dá as costas para você, nem bom dia te dá, com medo. É o que te falei, fé em Deus e bola para frente.

P: Você contou para alguém da equipe do PSF do seu diagnóstico?

R: A E [enfermeira] sabe, e a F. [ACS]. só. A F. é agente médica. E a enfermeira, que eu confio muito, só. O resto...

$\mathrm{P}: \mathrm{E}$ foi você que contou para a enfermeira? 
R: Foi eu mesma que contei. Eu chamei ela, conversei com ela. Inclusive ela me deu até uns conselhos, sabe? Para fazer o tratamento direitinho, .erguer a cabeça, que eu tenho filhos para criar. Tipo assim, eu peguei algumas palavras que ela me disse e estou utilizando, entendeu? É isso aí.

P: O que você pensou antes de contar para ela?

R: Eu não pensei nada, porque tipo assim, se elas são médicas, enfermeiras, elas estão acostumadas, elas não iam me dar as costas. A E. [enfermeira] eu tinha certeza que ela não ia me dar as costas. E por isso hoje eu tenho ela como uma irmã. A irmã me deu as costas, quer dizer, as minhas irmãs de sangue me deram as costas e ela não. E é isso... ela, a F.

P: É bom ter elas para te ajudar...

R: É. Às vezes eu estou aqui, passei no médico, e eu vou lá conversar com a E.[enfermeira]. E a E. sempre me ajuda, sempre me dá um conselho, uma palavra amiga.

P: E da equipe, você também não quer contar para mais ninguém?

R: De lá?

P: É.

R: Não, eu não confio. As pessoas que trabalham lá são do bairro. A única pessoa que eu fiz assinar, que se falasse eu colocava ela presa, foi a F. [ACS]. Ela falou - não, lógico, a gente não tem esse direito -. Ela toda a vida me passou confiança, em nenhum momento eu desconfiei dela. E ás vezes os demais não, eles são do bairro, daquele tipo... Na hora não, mas depois ficam assim... sabe... então, os outros, tirando a E. [enfermeira] e a F. [ACS], o resto não confio. E ela sabe disso, que eu não confio. 
P: nem a médica da equipe?

R: só a Dra. C.[médica da equipe]. Só a Dra. C., o resto...

P: então a Dra. C. também sabe?

R: Sabe. A Dra. C. sabe, porque ás vezes assim... eu peguei uma bactéria, no estômago e no intestino. Aí tanto como eu vomitava como tinha diarréia. E a Dra. C., tipo assim, me dava os remédios, eu ia lá, tomava soro. Até eu vinha aqui na Dra. L. [médica do $\mathrm{SAE}$ ] e ela me receitava o remédio certo para matar as bactérias. Só, porque o resto não confio, não. É um direito que eu tenho. A pessoa mora ali, então, que nem você falou, do bairro. A maioria das pessoas que trabalham ali são do bairro, e muitos ali não me inspiram confiança. Então, eu encontrei a E. [enfermeira], foi a primeira a saber, que eu conversei com ela, toda a vida conversei com a E.[enfermeira], da equipe. Ela foi a primeira, e depois veio a F. [ACS]. Ás vezes vem as outras pessoas da equipe lá, procuram saber, eu dou uma enrolada, mas nunca falo. Eu mais engano do que falo.

R: É, eu não confio. Não me fio. Isso aí.

P: Obrigada.

R: Do jeito que eu sou. Tenho meus filhos, tenho minha vida. É só, é bola para frente, confiando em Deus. Tipo assim, você pode ter o problema que você tiver, o importante é que você tenha fez em Deus e equilíbrio, o resto não conta. Porque eu era para ser assim, uma pessoa triste, me entregar mesmo para a doença. Por que?, porque minha mãe me deu as costas, minhas irmãs, minha família em geral. E não, eu sou feliz, mesmo quando me deram as costas. Tenho meus filhos, meu marido. Tenho uma casinha humilde, simples, mas é minha. Então, a 
E.[enfermeira] para mim ela é tudo. Uma mãe, uma irmã, uma amiga. Sempre que eu preciso ela está ali, ela nunca me falou- não - . Quando eu preciso ela está aí.

P: Então, obrigada por você ter participado. É muito importante para a gente ver como as coisas estão andando.

R: Era bom que a maioria do pessoal estivesse que nem eu, e eles não estão, eles ficam - ah, tenho gripe, tenho pneumonia -, começam a ficar ruim mesmo. Eu não, eu tenho fé em Deus. Um dia vou morrer, não é?

P: Muito obrigada, é muito importante a sua participação, muito mesmo, de verdade.

R: Tá bom. Quando precisar... 


\section{ANEXO 1}

Número do questionário:

Data:

Pesquisadora:

A- Dados pessoais e condições de vida:

1. Data de nascimento:

2. Anos completos de estudo :

3. Situação de emprego:

4. Número de filhos que moram com você:

5. Idade deles:

6. Quais são as pessoas que residem junto com você na mesma casa?

7. Renda total da casa: Renda per capita

8. Você participa de alguma associação, igreja, œntro comunitário ou ONG?

9. Há quanto tempo você mora neste bairro?

10. Há quanto tempo você sabe do diagnóstico? 
B- Roteiro semi-estruturado

Questões norteadoras

1. Conte como foi para você quando que você soube que estava infectada pelo HIV?

( )Contou para alguém assim que soube? ( ) Para quem você contou primeiro?

2. Como foi para você, contar pela primeira vez a alguém, que estava infectada?

( ) E, depois contou para mais alguém ?

3. Você guarda segredo sobre seu diagnóstico para alguém?

4. Você já morava no bairro em que mora hoje quando soube do diagnóstico?

5. Ser HIV positiva interfere em alguma coisa sua convivência no bairro onde mora?

6. Você contou para alguém da equipe do PSF sobre seu diagnóstico?Em que você pensou para tomar essa decisão de ? 


\section{ANEXO 2}

\section{Termo de Responsabilidade da Pesquisadora}

Meu nome é Fernanda Cristina Ferreira. Sou aluna do Programa de Pós-graduação da Escola de Enfermagem da USP e estou realizando um estudo que tem como finalidade contribuir para melhorar a assistência prestada a mulheres infectadas pelo HIV/AIDS no Programa Saúde da Família.

Peço sua participação em uma entrevista a ser gravada, que tem como objetivos compreender o significado da revelação do diagnóstico de soropositividade ao HIV à equipe de PSF e conhecer as motivações para a revelação ou não deste diagnóstico.

Não é necessário que você se identifique, pois quero manter seu anonimato, garanto que na transcrição das fitas serão excluídos nomes ou qualquer particularidade eventualmente citada e que, por acaso, possibilitem identificações. As informações fornecidas por você serão utilizadas somente para as finalidades deste estudo.

Se você não quiser participar deste estudo, não haverá prejuízo algum ao seu atendimento nesta ou em outras unidades de saúde, se você aceitar participar, terá liberdade para desistir a qualquer momento. Este estudo não terá custos ou remuneração para você.

Se tiver qualquer dúvida, ou quiser saber os resultados desta pesquisa, entre em contato nos seguintes telefones: $9275-8199$ ou $6424-1850$ ou no e-mail: fernandausp@terra.com.br

Muito Obrigada,

$\begin{array}{ll}\text { Fernanda Cristina Ferreira } & \text { Lúcia Y. Izumi Nichiata } \\ \text { Pesquisadora } & \text { Orientadora }\end{array}$

Qualquer questão, dúvida, esclarecimento ou reclamação sobre os aspectos éticos desta pesquisa, favor entrar em contato com: Comitê de Ética em Pesquisas da Secretaria Municipal da Saúde de São Paulo- Rua General Jardim, 36- $2^{\circ}$ andar - Telefone: 3218-4043 - e-mail: smscep@ prefeitura.sp.gov.br 